\title{
LA MARCA MED «MEDICINA Y CIENCIAS DE LA SALUD» EN LAS DOS EDICIONES DEL DICCIONARIO DEL ESPAÑOL ACTUAL: TIPOLOGÍA DE LOS CAMBIOS
}

\author{
The Med "Medicine and Health Sciences" mark on two editions of the "Diccionario del \\ Español Actual": Typology of changes
}

\author{
Margarita Cundín Santos* \\ Roberto Olaeta Rubio**
}

\begin{abstract}
RESUMEN
La publicación de la segunda edición del Diccionario del Español Actual (DEA) y el lapso de tiempo transcurrido entre una edición (1999) y la otra (2011) han sido la excusa idónea para estudiar el proceso de renovación léxica experimentado por nuestra lengua en los últimos años en el campo científico de la Medicina y las Ciencias de la salud, así como la tipología de los cambios en la práctica lexicográfica que se puede observar en este preciado diccionario. Las novedades no son únicamente de tipo cuantitativo, sino que obedecen a otras razones: se modifican las definiciones para conseguir mayor claridad o precisión, se consignan cambios en la marcación de las voces y se eliminan algunos artículos desusados en la actualidad o por consignarse en otro artículo lexicográfico.

Palabras clave: renovación léxica, modificación de la microestructura, cambio de marca.
\end{abstract}

\begin{abstract}
The publishing of the second edition of the Diccionario del Español Actual (DEA) and the time passed between editions (the first in 1999 and the second in 2011) was a good reason to study the renewal of the the Spanish lexicon in the field of Medicine an Health Science during the last years, as well as the typography of changes observed in practical lexicography in this valuable dictionary. Novelties are not only quantitative but they obey to other reasons: definitions are modified to obtain more clarity or accuracy, new marks are assigned to words and obsolate article are eliminated or they are replaced for anothers in use.
\end{abstract}

Key Words: lexicon renewal, microstructure modification, mark change. 


\section{Introducción}

Con motivo de la elaboración del Vocabulario médico. Con todas las voces recogidas en los diccionarios de uso (Olaeta y Cundín 2011), se llevó a cabo un estudio detallado de la terminología médica incluida en algunos de los diccionarios generales de lengua de uso más frecuente entre los hablantes de español, entre ellos el Diccionario de español actual (DEA 1999). Durante la elaboración del Vocabulario se pudo comprobar la disparidad de criterios que emplean los diccionaristas a la hora de marcar técnicamente las voces, criterios que son desconocidos, pues en ningún diccionario se explica los acuerdos alcanzados para colocar una marca técnica a un determinado sentido, ni tampoco cómo diferenciar lo que se considera propio del campo de la medicina de lo que se marca con otras etiquetas del ámbito de las ciencias de la salud, como anatomía, cirugía, psicología, farmacia, biología, etc. Asimismo se confirmó que DEA es el diccionario que compila el mayor número de tecnicismos del ámbito de la medicina y ciencias de la salud.

La publicación de la segunda edición del DEA y el lapso de tiempo transcurrido entre una edición (1999) y la otra (2011) han sido la excusa idónea para comprobar el proceso de renovación léxica experimentado por nuestra lengua en los últimos años en el campo científico de la Medicina y las Ciencias de la salud.

De todos es conocida la revolución que supuso la publicación de la primera edición del Diccionario de español actual, pues hasta ese momento, la lengua española «no disponía de un inventario léxico realizado con un metodología medianamente rigurosa» (DEA "Preámbulo": XI). La confección del DEA conlleva un punto de partida diferente al de otros diccionarios de la lengua española: la creación de una base documental que muestra cómo funcionan en la frase las palabras y cómo se relacionan con otros elementos del enunciado. Nos hallamos, pues, ante un diccionario notablemente innovador con respecto a otros diccionarios generales de lengua del español.
Desde el punto de vista cuantitativo, la segunda edición del DEA presenta una clara renovación: 83000 artículos frente a los 75000 de la edición anterior; y el número de acepciones pasa de 141000 a 198000 en esta última edición. Pero la renovación del diccionario no solo afecta al aumento de artículos y acepciones, sino también a la supresión de algunas entradas, al cambio de la marca que corresponde al ámbito científico y a la modificación del contenido de la microestructura.

Este trabajo, pues, tiene como propósito estudiar las innovaciones que afectan a los términos y acepciones con la marca «Medicina y Ciencias de la salud» en esta nueva edición.

\section{Tipología de cambios en DEA 2011}

Se ha observado que las novedades afectan a: 1. Inclusión de nuevas entradas o artículos; 2. Modificación de la microestructura: se redactan nuevas acepciones; se modifican algunas definiciones; se cambia la marca de algunas voces; 3 . Eliminación de artículos.

\subsection{Nuevos artículos}

El incremento del número de artículos en el ámbito científico de la medicina es considerable: 247 nuevas entradas (vid. Anexo I). La mayoría de ellas (155) corresponden a la categoría de sustantivos; le siguen en número los adjetivos (81); y apenas encontramos nuevos artículos correspondientes a otras categorías gramaticales (verbos, 6; prefijos, 4).

\subsubsection{Macroestructura de las nuevas entradas}

\subsubsection{Sustantivos}

La mayoría de los sustantivos incorporados en esta nueva edición hacen referencia a médicos especialistas en diferentes ámbitos de la medicina, a las propias ramas de la medicina, a tratamientos terapéuticos y quirúrgicos, a enfermedades y aparatos para diagnosticar o tratar algunas dolencias, de ahí 
que en su formación se hallen pseudoprefijos y pseudosufijos de uso muy frecuente en medicina, casi siempre en la misma posición, y que poseen el contenido semántico de un sustantivo. Se trata de nombres formados con -logía 'tratado, estudio' (neurohistología, cinesiología), -terapia 'tratamiento' (risoterapia, algoterapia), -logo 'especialista' (implantólogo), -algia 'dolor' (fibromialgia, pubalgia), -grama 'gráfico' (electromiograma), -grafo 'que describe' (angiógrafo, espirógrafo), -metro 'medida' (dolorimetro, pulsímetro), -scopia 'examen, exploración' (histeroscopia, rinoscopia), -scopio 'instrumento para examinar' (artroscopio, laparoscopio), -tomía 'corte, incisión' (colectomía, queratomía), -plastia 'reconstrucción' (abdominoplastia, gastroplastia), alo- 'diferente' (aloinjerto, alotrasplante), xeno- 'ajeno, extraño' (xenoinjerto, xenotrasplante).

Formados por composición se han incorporado una serie de sustantivos que son compuestos propios o univerbales (coronavirus, papilomavirus), otros son compuestos acronímicos (bacteriuria), y, en otras ocasiones, los elementos del compuesto aparecen unidos por un elemento de unión, que suele ser la vocal $-O$ - para los términos de origen griego (venopunción, fibrosarcoma, varicocele).

Con el formante - $\log$ o se han incluido 20 términos nuevos, que denominan a los estudiosos de las numerosas ciencias modernas terminadas en -logía y que en el diccionario se definen como 'especialista en' seguido del nombre de la rama de la medicina correspondiente: paidólogo 'especialista en paidología'; mastólogo 'especialista en mastología', etc. En la primera edición, es probable que los autores del diccionario se sirvieran de la competencia lingüística de los usuarios para no validar algunos sustantivos formados con -logo, ya que su sentido es fácilmente deducible del de la rama de la medicina correspondiente. Llamaba la atención, entonces, que, a pesar de que los términos con los que se designan a los especialistas estuvieran documentados y fueran usados con frecuencia, unos se lematizaran y otros, no.
De todos los que se recogen en la segunda edición, resulta cuando menos curiosa la presencia del término urgentólogo, pues su uso es bastante restringido (solo se ha documentado en tres artículos de revistas especializadas (2 en CES Medicina de Colombia y 1 en Archivos de medicina de urgencia de México) $\mathrm{y}$, de hecho, no se encuentra entre las páginas de ninguno de los diccionarios especializados consultados (Diccionario de Términos Médicos [DTM], Dorland, Mosby). Por otro lado, cabría preguntarse por qué se incluye urgentólogo y no urgenciólogo, término preferido en la literatura médica (se han hallado 125 documentos especializados donde se incluye urgenciólogo), y por qué se dejan de lado los términos que designan la especialidad médica que practican estos profesionales, esto es, la urgentología o urgenciología, pues se emplean en América y se documentan en la misma medida que urgentólogo.

Respecto de la voz griega terapia 'cuidado, atención, tratamiento médico', aparece como elemento final en 16 nuevos compuestos. Este elemento en griego funciona como término simple y como pseudosufijo, lo que no hace más que corroborar que en el lenguaje científico, al contrario de lo que ocurre en la lengua común, la composición a partir de un mismo formante da lugar a la creación de un extraordinario número de términos.

Los sustantivos, ahora incluidos, formados a partir de este pseudosufijo se corresponden con dos tipos diferentes de practicar y de entender la medicina: el tradicional o convencional y la medicina alternativa. Pertenecen al primer tipo los términos braquiterapia, corticoterapia, dietoterapia, escleroterapia y monoterapia. Sin embargo, la mayor parte de ellos donotan procedimientos terapéuticos propios de la medicina alternativa, carentes de fundamento científico, que se sirven de determinados elementos, como por ejemplo, algas, aceites esenciales, compuestos aromáticos, la luz de distintos colores, diferentes minerales, algunos animales, la risa etc., con la pretensión de que estos puedan modificar el estado de ánimo de las personas con fines curativos. Así, fruto 
del auge de la medicina alternativa se han incorporado algoterapia, aromaterapia, chocoterapia, colorterapia, delfinoterapia, gemoterapia, hipnoterapia, risoterapia, etc. La mayoría de estas voces no se compilan en los diccionarios terminológicos. Por el contrario, en las obras especializadas se halla un elevado número de términos que refieren procedimientos terapéuticos de la medicina convencional (psicoterapia, aerosolterapia, oxigenoterapia, osmoterapia, antibioticoterapia, piretoterapia, etc.).

Llama la atención que en la 2. ${ }^{a}$ edición del diccionario se haya validado el término monoterapia, mientras que su antónimo politerapia no se incluye, y es más llamativo si tenemos en cuenta que la politerapia es la manera más habitual de combatir las enfermedades y que son numerosas las fuentes donde se documenta el término. Con la lectura de la definición de monoterapia 'Terapia con un solo tratamiento o medicamento' se corre el riesgo de confundir estas dos modalidades terapéuticas debido a la semejanza de los campos temáticos. El tratamiento de una enfermedad con una sola modalidad terapéutica se conoce también con los términos terapia única, tratamiento único, que no es lo mismo que monofarmacoterapia o monoterapia farmacológica que denota el tratamiento de una enfermedad con un solo medicamento. Por su parte, a politerapia le corresponden los sinónimos terapia asociada, terapia combinada o terapia múltiple, que designan el tratamiento de una enfermedad con dos o más modalidades terapéuticas a la vez, términos que no deben confundirse con polifarmacoterapia, poliquimioterapia, politerapia farmacológica, terapia multimedicamentosa, que hacen referencia al tratamiento de una enfermedad con dos o más medicamentos de forma simultánea.

Por otro lado, en las últimas décadas del siglo $\mathrm{XX}$ y principios del XXI, gracias a la proliferación de clínicas destinadas a la cirugía con fines estéticos, se han popularizado numerosos términos compuestos a partir del elemento - plastia, lo que se refleja en su inclusión en las obras lexicográficas de carácter general. En la primera edición del diccionario se lematizaron 13 términos formados con plastia; en la segunda edición se han añadido 4 más: abdominoplastia, gastroplastia, otoplastia y valvuloplastia. Sin embargo, el número podría haberse incrementado considerablemente, puesto que cualquier parte del organismo puede someterse a una reconstrucción y porque son de sobra conocidos por la mayoría de los hablantes y están fielmente documentados términos como labioplastia, blefaroplastia, clitoroplastia, ritidoplastia, toracoplastia, faloplastia, mamoplastia, etc.

En el vocabulario médico empezó a usarse este elemento en el siglo XIX y desde entonces su empleo ha proliferado, de manera que, en la actualidad, abundan los sustantivos que utilizan el término -plastia ('remodelación quirúrgica') como elemento compositivo. Habitualmente se combina con el nombre de la parte anatómica que sufre esa remodelación: timpanoplastia, piloroplastia, etc. Por consiguiente, el término se aplica a aquellas intervenciones que tienen por objeto cambiar o modelar alguna parte del cuerpo (fin estético: abdominoplastia) o a aquellas cuyo fin es restablecer, mejorar o modificar la función de un órgano del cuerpo (fin terapéutico: valvuloplastia, gastroplastia).

Un claro ejemplo de remodelaciones quirúrgicas con fines estéticos, según las explicaciones facilitadas en DEA, son abdominoplastia y otoplastia. Abdominoplastia es voz muy frecuente en los folletos publicitarios e informativos de los centros de cirugía estética, por su valor descriptivo $\mathrm{y}$, de hecho, las citas que ilustran el término hacen referencia a los servicios que ofrecen determinadas clínicas de cirugía estética: «ASM n ${ }^{\circ}$ 1.88, 8: Clínica Vinkal.. Abdominoplastia. Rinoplastia. GTelefónica 00 1212: Cirugía plástica y estética. .. Liposucción. Abdominoplastia». Sin embargo, en obras científicas o en diccionarios especializados el término más frecuente es dermolipectomía o simplemente lipectomía abdominal. Así, el DTM no recoge abdominoplastia, sin embargo, en la entrada lipectomía refiere 'Extirpación quirúrgica de una porción de tejido adiposo’ y en las observaciones añade: «Se usa con frecuencia 
en un sentido más restringido, referido tan solo a la lipectomía abdominal en casos de obesidad. No debe confundirse con liposucción». Esto significa que en denominaciones de términos científicos se pueden distinguir los nombres populares y los científicos o técnicos, generalmente en griego o en latín.

Elúnico sentido que se recoge en otoplastia está en relación directa con la cirugía estética, sin embargo, esta denominación no solo hace referencia a la corrección de las deformidades o el tamaño de la oreja, sino también a la reconstrucción del pabellón auricular.

Asimismo, fruto del avance científico y de la invención de nuevas técnicas diagnósticas y terapéuticas, es habitual la creación de sustantivos que designan los aparatos para la realización de pruebas y los resultados con ellos obtenidos. En el diccionario se observa un incremento considerable de términos formados a partir de elementos que indican registros gráficos, descripción, contemplación o examen, etc.: angiógrafo, ecocardiógrafo, pletismografía, venografía, electromiograma, planigrama, artroscopio, laparoscopio, histeroscopia, rinoscopia son algunos ejemplos.

Por otro lado, cabe destacar el número de tecnicismos validados formados por sufijación. Entre los sufijos más usados, unos son los propios del lenguaje común: -ista (terapista, periodontista, fisioterapista), -ismo (bruxismo, puerilismo, vaginismo), -ción (variolación, demenciación), -aje (curetaje); otros términos presentan sufijos específicos del ámbito de la medicina: -itis 'inflamación' (fascitis, tromboangitis), -osis 'enfermedad, estado irregular' (apoptosis, carcinomatosis, poliposis), -oma 'tumor' (fibrosarcoma, neuroma, papilomavirus).

Llama la atención el elevado número de sustantivos incorporados en la 2. ${ }^{\text {a }}$ edición formados con el sufijo -ia (para la acentuación de este sufijo, vid. Martínez de Sousa 2004: 196-7), que se añade no solo a palabras individuales (aniridia, atopia), sino también a las compuestas con elementos finales, como -terapia, -fagia, o-algia.
En época moderna, la medicina se ha servido del sufijo -itis para crear una serie de términos que denominan inflamaciones. Dos son los términos formados con este sufijo que se han incluido en la actual edición: fascitis y tromboangitis, ambos documentados desde principios del siglo XX.

Otro sufijo propio del vocabulario técnico médico es -osis, utilizado para formar nombres de enfermedades sobre bases nominales griegas o latinas. Se incluyen en esta edición carcinomatosis (karkínomat 'lesión cancerosa' + osis 'proceso patológico'), granulocitosis (granulocito + osis), legionelosis (latín científico Legionella, de legión + -ella latín científico 'bacteria'), poliposis (polypous + osis) y queratosis (kerat- 'de textura córnea' + -osis). Aunque entre los profesionales de la medicina queratosis se usa frecuentemente, es preferida la forma hiperqueratosis, que el DEA no recoge.

La prefijación es otro de los sistemas más productivos en el lenguaje científico, con el que se modifica el significado de las distintas raíces. Se pueden expresar sentidos idénticos mediante el uso de varios prefijos. Encontramos, de esta manera, nuevos términos incorporados formados con los prefijos de valor negativo o de ausencia a-, an-, di(s)-, (aniridia, anósmico, atopia, anafrodisia, apraxia, disfásico) y de repetición o de intensificación re-(revascularización).

También se han incorporado lexías simples de procedencia extranjera que presentan distintos grados de adaptación. Así procedentes del latín se han incluido bifidus o lumen. Bífidus es la forma coloquial usada para designar al bacilo grampositivo Bifidobacterium bifidum, aunque la mayoría de los hablantes designan con este nombre a determinados productos lácteos. De procedencia inglesa se han incluido lumen 'espacio interior de una estructura o de la cavidad de una víscera hueca' (DTM); stent y estent, la primera anglicismo crudo y la segunda forma semiadaptada, aunque en la literatura médica se encuentran las variantes estén o estente; distrés con remisión a distress, variantes que en ocasiones suscitan rechazo por considerarse anglicismos, aunque cada vez su uso es más frecuente remplazando a otros 
términos como sufrimiento (en la expresión sufrimiento fetal) o dificultad (en la expresión dificultad respiratoria); ibuprofeno es otro de los términos de procedencia inglesa incluidos en esta edición.

De procedencia francesa se han incorporado: trocar (abreviación de trois-quart), cureta (de curer 'limpiar' + -ette 'pequeño') o el híbrido curetaje, son algunos ejemplos. Cureta cuenta con dos sinónimos en español: legra y cucharilla. En la actualidad, la preferencia por un sinónimo $\mathrm{u}$ otro depende de la forma del instrumento. Se prefiere legra o cucharilla si el instrumento tiene forma de cuchara y cureta si la legra tiene forma de banda elíptica.

En menor medida se han validado epónimos o tecnicismos formados por distintos procedimientos de abreviación. Se ha incluido el epónimo Chagas, formado exclusivamente por el apellido del médico e higienista brasileño, especialista en enfermedades infecciosas. Esta dolencia también se recoge en las entradas enfermedad y mal como término formado por sintagmación, y sin marca diatécnica alguna, en este caso, se especifica que puede escribirse con minúscula.

El número de nuevas entradas que remiten al ámbito de la medicina podría incrementarse si tenemos en cuenta que se han validado sin marca términos populares como mal de altura o de las montañas, mal de las vacas locas, mal de mar o enfermedad del sueño, enfermedad del legionario, enfermedad sagrada, etc. En algunos casos, estas denominaciones populares tienen correspondencia con los nombres científicos que se consignan con la marca diatécnica, como es el caso de enfermedad del legionario con remisión al término científico legionella; sin embargo, en enfermedad sagrada reza 'epilepsia' y esta se consigna sin marca alguna.

Formados por acronímica se incorporan volemia, procedente del latín científico uol(ūmen) 'volumen' + -haimía 'sangre', tularemia de Tular(e) 'condado de California' + haimía 'sangre', sexomnia (sexo + somnia) y sexomnio (sexo + somnium), y por siglación PET y VIH (respecto del desbarajuste terminológico para nombrar estos acortamientos, vid. Calvet 1980, Kocourec 1991, Lang 1992 y Nedobity 1981).

En el caso de la medicina algunos nombres tienen como origen un valor connotativo: la evocación de una imagen asociada a una realidad. En este sentido, la metáfora es uno de los medios más eficaces para la dotación de nuevos sentidos a significantes ya conocidos, como son los casos de puente o ventilador, adscritos, por primera vez, al ámbito de la medicina en un diccionario general de lengua.

\subsubsection{Adjetivos}

La mayoría corresponden al tipo de adjetivos relacionales. La renuncia a incluir estos adjetivos como artículos independientes en la primera edición del diccionario pudo deberse a que su sentido es fácilmente deducible a partir de la base léxica correspondiente, evitando, así, incrementar el volumen de la obra. Sin embargo, en la segunda edición, sin explicación alguna en la «Nota para la segunda edición» ni en las páginas introductorias, se incluyen adjetivos formados por prefijación y sufijación, como son:

1.- Adjetivos relacionales. Destacan los formados con el sufijo $-i c o /-i c a$, que conforman derivados esdrújulos. Cuantitativamente hablando, es el más numeroso (54) y remiten a enfermedades (adinámico, aerofágico, apoptótico, tiflotecnológico, triquinósico, etc.), a pruebas diagnósticas y terapéuticas (arteriográfico, ecocardiográfico, electromiográfico, polisomnográfico, etc.) y, por último, a las distintas ramas de la medicina (alergológico, cinesiológico, flebológico, iridológico, neuroendocrinológico, etc.).

Asimismo, encontramos adjetivos con el sufijo -al (podal) y los derivados deadjetivales formados por prefijación (antirretroviral, retroviral y transvaginal). La proliferación del uso de este sufijo para la formación adjetiva a partir de sustantivos se debe, sin lugar a dudas, a la influencia del inglés. 
2.- Adjetivos formados con el sufijo de sentido activo -dor: pronador y supinador. Se trata de adjetivos con base nominal (pronación y supinación respectivamente), aunque admiten usos sustantivos, como se aprecia en la cita que acompaña las definiciones.

La forma de validar estos términos presenta claras diferencias en los diccionarios terminológicos y en los generales de lengua. Así, en DTM, los adjetivos pronador y supinador no toman como referentes personas, sino que se definen con una explicación relativa: 'lo que produce pronación' (o supinación, según el término que se esté definiendo); en los usos sustantivos se refieren a los músculos pronador y supinador, sentido que recoge el DEA en la primera acepción con marca Anat. Sin embargo, el DTM incluye en la entrada pie los sentidos recogidos en DEA con la marca «medicina» en los artículos pronador y supinador. Así pues, se consignan los lemas compuestos pie valgo o pie pronado (también pie abducto) y pie varo o pie supinado (también pie aducto). En DEA, por el contrario, en la entrada pie se realiza una remisión a los artículos valgo y plano, sin recoger ninguna referencia al adjetivo varo (vid. Anexo II).

3.- Adjetivos formados con el sufijo -nte: Se caracterizan por tener base verbal, mantener la terminación de los antiguos participios de presente y admitir, en numerosas ocasiones, usos nominales (bloqueante, esclerosante).

4.- Adjetivos procedentes de verbos con sentido pasivo son los formados con el sufijo -ble. Hallamos en este apartado dializable, que tiene sentido pasivo $\mathrm{y}$ modal, como se refleja en su definición: 'que se puede dializar', esto es, que se puede someter a diálisis.

5.- Otros adjetivos están formados con elementos compositivos procedentes de otras lenguas, sobre todo, como es de esperar, del griego y del latín. Del griego -oide, formante que denota parecido o semejanza, se ha incorporado cannabinoide (en los textos médicos se prefiere la grafía canabinoide); asimismo del griego -manía , hallamos el formante maníaco 'persona que padece manía': potomaníaco. Del latín -forme $(m)$ 'que tiene forma de', encontramos espongiforme; y de -cìda' eliminación o acción de matar', feticida.

De procedencia inglesa, -pathic que denota padecimiento de una enfermedad (valor que deriva de -patía) hallamos encefalópata.

\subsubsection{Verbos}

Apenas sí se incorporan en esta edición nuevos verbos con marca «medicina», en concreto, seis: criogenizar, demenciarse, legrar, mastectomizar, necrotizar y variolizar. Cabe destacar que la presencia de estos verbos no es frecuente ni en las obras lexicográficas especializadas ni en las de carácter general: legrar se incluye en DRAE y VOX con marca Med.; en DUE y DSLE con marca Cir., y en CLAVE sin marca. El resto de verbos no figuran en ninguno de los diccionarios mencionados. Por su parte, el DTM incluye demenciarse, mastectomizar y necrotizar.

Desde el punto de vista morfológico, cuatro se han formado con el sufijo-izar. Se trata de un sufijo muy conocido en la formación de verbos con valor causativo, y muy productivo en la creación de neologismos (vid. Rebollo 1991). El DUE (2007: 1693) refiere de este sufijo: «[...] sirve para formar verbos derivados de nombres o adjetivos, significando "convertir en" o "comunicar"». En el ámbito de la medicina, ha desplazado al sufijo - $a r$, sobre todo en la formación de verbos a partir de sustantivos de origen griego terminados en -isis. En las innovaciones incorporadas en esta edición, la base que predomina son los sustantivos (criogénesis, mastectomía, necrosis y variolización) y, de hecho, la mayoría de las definiciones se redactan 
tomando como eje central estos sustantivos: mastectomizar 'practicar una mastectomía', necrotizar 'necrosar', esto es, 'producir necrosis [en una parte del organismo]'; en este caso, se comprueba que el verbo necrotizar tiene otra forma equivalente, necrosar, a la que remiten los diccionarios que la incluyen. Por su parte, variolizar ha podido tomar como base el adjetivo variolar 'varioloso', 'que tiene granos y manchas similares a las vesículas de la viruela' o bien el sustantivo variolización forma preferida a variolación.

Aunque legrar se puede documentar en diccionarios y obras especializadas desde el siglo XVII, su uso no ha sido habitual y si exceptuamos el DRAE, donde figura desde la edición de 1734 hasta la última, su presencia en los diccionarios generales de lengua es rara. Por otro lado, obras especializadas de reciente publicación (tal es el caso del DTM) no lo incluyen entre sus páginas y en la literatura médica se prefieren las expresiones «practicar un legrado» $\mathrm{o}$ «raspar con la legra».

\subsubsection{Prefijos}

Entre las innovaciones del diccionario destaca la inclusión de cuatro prefijos, tres procedentes del griego científico: angio-, gr. angeio- 'vaso sanguíneo', onco-, gr. onko- que indica 'masa cancerosa' y querato-, gr. $\operatorname{kerat}(o)$ 'cuerno', 'córnea', y uno de latín: cervico-, lat. ceruīc 'cuello' y en latín científico 'cuello del útero'. Aunque en el ámbito de la medicina son prefijos muy prolíficos, y los diccionarios especializados compilan numerosos términos que contienen estos formantes, su presencia en los diccionarios, tanto especializados, como en los generales de lengua, es prácticamente nula. No se encuentran en el DTM y solo algunos diccionarios generales de lengua los incluyen entre sus páginas.

\subsubsection{Redacción de las nuevas entradas}

En la «Guía del lector», se advierte que las definiciones de los tecnicismos o de aquellas voces que pueden ser objeto de estudio por parte de especialistas están redactadas pensando en los hablantes comunes, que buscan una definición suficiente, no exhaustiva (DEA, XXI). Así, un buen número de definiciones responden a un modelo parafrástico, es decir son definiciones conceptuales. En numerosas ocasiones, se aprecia una gran uniformidad en la redacción, optando por definiciones patrón: las ramas de la medicina, los especialistas en esas ramas, los instrumentos médicos, las pruebas realizadas a los pacientes, etc., siguen un mismo esquema, los sustantivos buscan un hiperónimo:

fisiopatólogo -ga $m$ y $f(\mathrm{Med})$ Especialista en fisiopatología.

tiflólogo-ga $m$ y $f(M e d)$ Especialista en tiflología.

neuropsicología ( $t b$, más raro, neurosicología) $f$ (Med) Rama de la medicina que trata de los casos a la vez neurológicos y psicológicos.

angiógrafo $m$ (Med) Aparato para realizar angiografías.

ecocardiógrafo $m$ (Med) Aparato para realizar ecocardiografías.

También las definiciones de los adjetivos se ajustan a un modelo definitorio previo: se han explicado por medio de definiciones relacionales relativas o prepositivas. El profesor Ahumada (1989: 241) defiende la definición de tipo relacional como propia y más ajustable al adjetivo. Siguen un modelo exclusivamente prepositivo las definiciones de los adjetivos referentes a pruebas diagnósticas o a los aparatos para realizar esas pruebas:

electroencefalográfico -ca adj (Med) De (la) electroencefalografía.

electromiográfico -ca adj (Med) $\operatorname{De}(1)$ electromiógrafo.

En la misma línea, los adjetivos que hacen referencia a enfermedades, dolencias o trastornos se explican mediante dos acepciones: la primera, prepositiva introducida por $d e$, y la segunda toma la forma de oración de 
relativo o adjetivo sintáctico, para ajustarse, en la medida de lo posible, a la identificación entre la macroestructura y la microestructura, pues en la práctica lexicográfica actual se concibe «la definición como una expresión equivalente sintáctica y semánticamente al definiendum» (Mederos 1994: 102):

aerofágico -ca adj 1 (Med) De (la) aerofagia. 2 $(\mathrm{Med})$ Que padece aerofagia. $T b n$.

alexitímico -ca adj 1 (Med) De (la) alexitimia. 2 (Med) Que padece alexitimia. $T b$, referido a pers.

Los adjetivos que se refieren al agente que provoca una enfermedad siguen un modelo semejante al mencionado más arriba: la acepción primera es una estructura disyuntiva formada por una explicación relacional prepositiva y otra relacional relativa cuyo núcleo lo constituye el verbo implicar, unidas por la conjunción disyuntiva $o$. Cuando el adjetivo tiene como referente personas afectadas por la enfermedad, se añade una segunda acepción siguiendo el modelo 'Afectado de X' o 'Que padece X':

apoptótico -ca adj (Med y Biol) De (la) apoptosis o que la implica

carcinomatoso -sa adj 1 (Med) De(l) carcinoma o que lo implica. 2 Afectado de cancer ${ }^{1} . T b n$, referido a pers.

coprolálico - ca adj 1 (lit o Med) De (la) coprolalia o que la implica. 2 (lit o Med) Que padece coprolalia. $\mathrm{Tb} n$.

Por último, los adjetivos que refieren distintos ámbitos de la medicina siguen el mismo modelo de definición relacional prepositiva que el grupo anterior, pero, en estos casos se añade el sintagma 'o de su objeto':

alergológico -ca adj (Med) De (la) alergología o de su objeto.

flebológico -ca adj (Med) De (la) flebología o de su objeto.

Los adjetivos de sentido activo que admiten usos nominales presentan, en su definición, una estructura relativa: pronador -ra adj 2 (Med) [Pers.] que apoya en exceso la parte interior del pie al correr

supinador -ra adj 2 (Med) [Pers.] que apoya en exceso la parte exterior del pie al correr

En otras ocasiones, la definición responde al modelo denominado sinonímico, pues así se evita la repetición de la misma definición en dos artículos lexicográficos. En cuanto al modelo de definición sinonímica que presentan los nuevos términos incorporados en esta edición se puede concluir lo siguiente: 1 . que este tipo de definición se utiliza muy poco; 2 . cuando se utiliza, predomina la definición sinonímica simple; 3. existen varios tipos de relación entre los términos definidos de esta manera y que a continuación se detallan:

El término especializado se define con una palabra más conocida: frémito 'estremecimiento o vibración', háptico 'táctil', lumen 'luz', distrés 'problema', puerilismo 'infantilismo', antineoplásico 'antitumoral'.

- Si el término está connotado de alguna manera, se define con una remisión al término especializado: ventilador 'respirador'. En este caso ventilador puede suscitar rechazo por considerarse anglicismo (inglés ventilator) con el sentido de 'maquina utilizada en anestesia y en unidades de cuidados intensivos para instaurar y mantener una ventilación artificial en el paciente' (DTM, s.v. respirador)

El término especializado se define con otro término especializado: posparto 'puerperio', amiloideo 'amiloide', planigrama 'tomograma', luminoterapia 'fototerapia', colorterapia 'cromoterapia', aloinjerto 'homoinjerto', alotrasplante 'homotrasplante', encefalía 'encefalopatía', epidemiologista 'e pi d e miólogo', esfig móm e tro 'esfigmógrafo', fotofóbico 'fotófobo', homeoterapia 'homeopatía', necrotizante 'necrosante', retroviral 'antirretroviral', tiflotecnia 'tiflotecnología', tiflotécnico 
'tiflotecnológico', triquinósico 'triquinoso', tromboembolismo 'tromboembolia', venografía 'flebografía', xenoinjerto 'heteroinjerto', xenotrasplante 'heterotrasplante', queratomía 'queratoplastia'.

- En ocasiones, no se puede hablar de definición sinonímica propiamente dicha sino de remisión a una variante gráfica más conocida o preferida en el ámbito de la medicina. Son los casos de cataplejía 'cataplexia', cinesiología 'quinesiología', estent 'stent', legionela 'legionella', pulsímetro 'pulsómetro', sexomnia 'sexomnio'. Otras veces, la variante gráfica se produce por adición de un infijo: variolación 'variolización'.

\subsection{Cambios en la microestrutura}

Las innovaciones practicadas en el interior del artículo lexicográfico responden, fundamentalmente, a tres tipos: por un lado, se observa la inclusión de nuevas acepciones; por otro, se aprecian cambios en el contenido de una misma explicación o definición; $y$, por último, los cambios afectan a la marcación de las voces.

La definición de los términos ha sido tratada por numerosos investigadores (Ahumada 1989: 70; Petrecca 1992: 251; Porto Dapena 2002: 176; Seco 2003: 436). Todos ellos apuntan hacia la misma dirección: si el diccionario es una obra de consulta destinada a un público no especializado, su consulta no debería suscitarle más dudas de las que tenía. De ahí que el mensaje de cada artículo lexicográfico debe ser claro y el léxico empleado sencillo para que no obligue a nuevas búsquedas dentro del diccionario o incluso fuera de él. En este sentido, cabe destacar que, en la redacción de los tecnicismos, el léxico empleado en el DEA es accesible para cualquier usuario, consiguiendo definiciones claras, exactas y concisas, pero además inteligibles. $\mathrm{Si}$ esta era una cualidad de la primera edición, este esfuerzo por lograr que el diccionario sea una obra útil y de consulta fácil se percibe en los cambios operados en esta segunda edición, que resumiremos a continuación.

\subsubsection{Redacción de nuevas acepciones}

En 57 ocasiones se añade una nueva acepción con la marca diatécnica «medicina» (vid. Anexo III). Muchas de estas nuevas acepciones corresponden a adjetivos relacionales (anoréxico, atáxico, dislálico, displásico, eccematoso, escrofuloso, glaucomatoso, paranoico, pelagroso, silicótico) que, en la $1 .^{\text {a }}$ edición, se referían exclusivamente a una enfermedad o dolencia (atáxico) o a la persona que padecía esa enfermedad (anoréxico). Pues bien, en la nueva edición se unifica la redacción de estos adjetivos relacionándolos tanto con la enfermedad como con la persona que la padece. Variantes de estas definiciones son las que no se relacionan con una enfermedad o trastorno propiamente dichos, sino con sus síntomas (pustuloso, tofoso). En estos casos, el sentido se expresa mediante una paráfrasis relativa con el verbo tener. En la siguiente tabla se pueden apreciar estas innovaciones:

TABLA 1

Nuevas acepciones

\begin{tabular}{lll}
\hline Término & Edición de 1999 & Edición de 2011 \\
\hline anoréxico -ca adj & Que padece anorexia. Tb n. & $\begin{array}{l}\text { (Med) De (la) anorexia o que la implica. 2 (Med) Que } \\
\text { padece anorexia. Tb } n .\end{array}$ \\
\hline atáxico -ca adj & De (la) ataxia. & $\begin{array}{l}\text { (Med) De (la) ataxia. 2 (Med) Que padece ataxia. Tb n, } \\
\text { referido a pers. }\end{array}$ \\
\hline pustuloso -sa adj & $\begin{array}{l}\text { Caracterizado por la presencia de } \\
\text { pústulas. }\end{array}$ & $\begin{array}{l}\text { (Med) De (las) pústulas o que las implica. 2 (Med) Que } \\
\text { tiene pústulas. Tb n, referido a pers. }\end{array}$ \\
\hline tofoso -sa adj & Que tiene o implica tofos. & $\begin{array}{l}\text { (Med) De (los) tofos o que los implica. 2 (Med) Que } \\
\text { tiene tofos. }\end{array}$ \\
\hline
\end{tabular}


Dejando de lado los adjetivos relacionales, se observa que tanto algunos términos habituales en la lengua estándar como otros propios del ámbito de la medicina se refieren a conceptos diferentes porque han desarrollado grupos de significados diferentes. En este sentido hallamos nuevas acepciones en: bipolar, caliente, casuístico, compasivo, conjugado, corroborante, crisis, gafa, garra, gaseoso, hábito, masivo, primario, puente, rodadero, sugestivo, tolerante y ventilador. Según Gutiérrez Rodilla (1998: 100)

Este proceso se suele llevar a cabo por transferencias de significados de unas ciencias a otras o, dentro de una ciencia, entre sus diferentes campos; pero, también, por préstamos desde el lenguaje común a la lengua especializada o viceversa, por razones de significantes similares, analogías, metáforas, etc.
En la segunda edición, algunas de las nuevas acepciones son propias de préstamos procedentes del lenguaje común (compasivo), aunque tampoco faltan las que, procediendo del lenguaje común, han sufrido un proceso de transferencia de sentidos de unas ciencias a otras, como conjugado que se adscribe a los siguientes campos científicos: «botánica» acepción 2; «física» acepción 3; «química» acepción 4; «matemáticas» acepción 5. Otras veces, en cambio, dejan sin especificar un campo científico concreto, por lo que figuran con la marca $E$ «especialidades varias» (bipolar); sea como fuere, con el paso del tiempo, estos términos han desarrollado un sentido técnico del que el diccionario se hace eco:

TABLA 2

Transferencia de significados de unas ciencias a otras

\begin{tabular}{|c|c|c|}
\hline Término & Edición de 1999 & Edición de 2011 \\
\hline bipolar adj & (E) Que tiene dos polos. & $\begin{array}{l}2 \text { (Med) [Trastorno] maniacodepresivo. } \\
\text { b) [Pers.] que padece trastorno bipolar. } \\
\mathrm{Tb} n\end{array}$ \\
\hline compasivo -va adj & $\begin{array}{l}\text { [Pers.] que siente compasión o } \\
\text { es propensa a sentirla. b) Propio } \\
\text { de la pers. compasiva. }\end{array}$ & $\begin{array}{l}\text { [Pers.] que siente compasión o es } \\
\text { propensa a sentirla. } 2 \text { [Cosa] que denota } \\
\text { o implica compasión. } 3(\mathrm{Med}) \text { [Uso] de } \\
\text { un medicamento antes de ser aprobado } \\
\text { oficialmente, por razones humanitarias. }\end{array}$ \\
\hline conjugado - da adj & $\begin{array}{l}5 \text { (Mat) [Línea o cantidad] } \\
\text { relacionada con otra por una } \\
\text { ley determinada. }\end{array}$ & $\begin{array}{l}6(\mathrm{Med}) \text { [Vacuna] de varios componentes } \\
\text { combinados. }\end{array}$ \\
\hline
\end{tabular}

Pero la polisemia a la que aludíamos en el párrafo anterior no es exclusiva del lenguaje común. Existe igualmente polisemia en el lenguaje de la ciencia, bien porque ya existía en los formantes que componen un término, bien porque, aun conteniendo un único sentido, con el paso del tiempo se le ha dotado de otro u otros significados: autolisis, cacosmia, carcinógeno, escíbalo, escrófula, pandémico, poligrafía, pronador, supinador, son algunos ejemplos. 
TABLA 3

Polisemia

\begin{tabular}{|c|c|c|}
\hline Término & Edición de 1999 & Edición de 2011 \\
\hline $\operatorname{cacosmia} f$ & $\begin{array}{l}\text { (Med) Percepción morbosa de malos } \\
\text { olores que no existen. }\end{array}$ & $\begin{array}{l}\text { (Med) Percepción morbosa de malos } \\
\text { olores que no existen. } 2(\mathrm{Med}) \text { Halitosis. }\end{array}$ \\
\hline carcinógeno -na adj & $\begin{array}{l}\text { (Med) Que produce cáncer. Tb. n. m., } \\
\text { referido a agente. }\end{array}$ & $\begin{array}{l}\text { Que produce cáncer. Tb. n. m., referido } \\
\text { a agente. } 2 \text { Med Carcinogénico [1] }\end{array}$ \\
\hline escrófula $f$ & $\begin{array}{l}(\mathrm{Med}) \text { Estado de debilidad general } \\
\text { con predisposición a enfermedades } \\
\text { infecciosas, especialmente } \\
\text { tuberculosis, que se manifiesta por } \\
\text { inflamación de los ganglios linfáticos. }\end{array}$ & $\begin{array}{l}\text { (Med) Estado de debilidad general } \\
\text { con predisposición a enfermedades } \\
\text { infecciosas, especialmente tuberculosis, } \\
\text { que se manifiesta por inflamación de } \\
\text { los ganglios linfáticos. } 2 \text { (Med) Absceso } \\
\text { o fístula propios de la escrófula [1]. Tb } \\
\text { la úlcera que produce. }\end{array}$ \\
\hline
\end{tabular}

Resulta curioso que entre los sentidos de cacosmia figure el de 'halitosis', pues en ninguno de los diccionarios médicos consultados se consideran voces sinónimas. Parece que se trata de una imprecisión léxica por paronimia, pues, en las obras especializadas la halitosis se identifica con cacostomía (de kakos- 'malo' y stoma 'boca': olor fétido de la boca), pero no con cacosmia 'percepción habitual de olores desagradables que no existen'; 'desviación del sentido del olfato que conduce a los pacientes a preferir ciertos olores desagradables o fétidos' (Olaeta y Cundín 2011: 98).

Asimismo sorprende la presencia de un nuevo sentido en el artículo escrófula, pues, entre los profesionales de la medicina, el término era muy frecuente antaño, pero hoy en día se usa poco: la denominación habitual para esta enfermedad es linfadenitis tuberculosa, término que no se incluye en DEA, si bien encontramos la forma simple linfadenitis 'inflamación de los ganglios linfáticos'. Respecto de carcinógeno, aunque es término de uso habitual, se usa más cancerígeno, a pesar de que se trata de un híbrido etimológico.
Escíbalo es otro de los términos a los que se añade una nueva acepción. En la $1 .{ }^{a}$ edición, se etiqueta con la marca diatópica reg «regional» y con el sentido de 'cagarruta'. En la 2. ${ }^{a}$ edición figura una única acepción etiquetada con marca medicina que reza 'porción de excremento duro en el intestino', a la que sigue una subacepción, con marca diastrática raro y el sentido de 'cagarruta'. En DEA no se relacionan los términos coprolito 'excremento fósil', adscrito al ámbito de la «geología», y escíbalo, etiquetado con la marca «medicina». Sin embargo, en los diccionarios médicos y obras especializadas estos dos términos se consideran sinónimos $\mathrm{y}$, no podemos obviar que, en la literatura médica, existe una clara preferencia por el término coprolito, o en su defecto por fecalito, voz que no se incluye en DEA, por lo que debería revisarse la redacción de la entrada coprolito.

En la nueva edición se mantiene sin modificación alguna la información de ciertos artículos correspondientes a términos que han perdido su primitivo sentido o este ha quedado desplazado en el uso con respecto a otros usos 
más actuales. Por ejemplo, el sentido que ofrece el diccionario de explantar pertenece al ámbito de la «biología», a pesar de figurar con la etiqueta «medicina»: 'Trasladar [tejidos vivos] de su lugar natural a un medio de cultivo'. La mayoría de referencias tanto en periódicos, como en revistas y manuales de medicina no registran ese sentido, sino el de 'Extraer un órgano o un implante', por lo que en este caso, también debería replantearse añadir una nueva acepción.

Asimismo, con el fin de reflejar el uso más generalizado del término en el ámbito médico, también deberían modificarse los sentidos de otras entradas, como tanatofilia, titilación o titilar, por poner algunos ejemplos. En la entrada tanatofilia 'gusto por todo lo que rodea al fenómeno de la muerte' se debería indicar en primer lugar el sentido actual del término, esto es, 'tendencia al suicidio o deseo enfermizo de morir'; en titilación 'acción de titilar' debería incluirse el sentido de 'hormigueo, cosquilleo o picazón suave'; y, en titilar 'rozar o estimular ligeramente [las mucosas nasales o el velo del paladar], para producir el estornudo o el vómito' habría que añadir 'producir o causar sensación de hormigueo, cosquilleo o picazón suave' y 'estimular una parte del organismo para producir una respuesta refleja', pues es muy probable que los usuarios cuando consulten alguno de estos términos vayan buscando el sentido más general y actual y no el vigente en épocas anteriores o el menos común en la actualidad.

\subsubsection{Modificación en la redacción de las definiciones}

La modificación en el interior de las definiciones se debe a varios factores (vid. Anexo IV). En primer lugar, a la necesidad de precisar el sentido del término y su objeto de aplicación y dar a la definición la mayor exactitud posible.

TABLA 4

Necesidad de precisión

\begin{tabular}{|c|c|c|}
\hline TÉRMINOS & DEFINICIÓN 1. ${ }^{\mathrm{a}}$ ed. & DEFINICIÓN 2.a ed. \\
\hline adenomatoso-sa $a d j$ & $(\mathrm{Med})$ Que tiene los caracteres del adenoma & $\begin{array}{l}(\text { Med }) \text { Del(1) adenoma o que tiene los } \\
\text { caracteres de(l) adenoma. }\end{array}$ \\
\hline afásico -ca adj & $2(\mathrm{Med})$ De (la) afasia. & $2(\mathrm{Med}) \mathrm{De}(\mathrm{la})$ afasia o que la implica. \\
\hline angioplastia $f$ & (Med) Cirugía plástica de los vasos sanguíneos. & $\begin{array}{l}\text { (Med) Cirugía reparadora de los vasos } \\
\text { sanguíneos, frec. mediante un catéter }\end{array}$ \\
\hline oncología $f$ & $\begin{array}{l}\text { (Med) Especialidad médica que estudia los } \\
\text { tumores. }\end{array}$ & $\begin{array}{l}\text { (Med) Especialidad médica que estudia los } \\
\text { tumores y esp. el cáncer. }\end{array}$ \\
\hline presoterapia $f$ & $\begin{array}{l}(\mathrm{Med}) \text { Tratamiento destinado a eliminar los } \\
\text { líquidos acumulados en las piernas, mediante } \\
\text { la introducción de estas en un aparato a modo } \\
\text { de bota. }\end{array}$ & $\begin{array}{l}(\mathrm{Med}) \text { Tratamiento destinado a eliminar los } \\
\text { líquidos acumulados en el cuerpo, esp. en las } \\
\text { piernas, mediante un aparato neumático que } \\
\text { se infla y desinfla alternativamente. }\end{array}$ \\
\hline carbuncosis $f$ & $(\mathrm{Med})$ Infección carbuncosa. & $(\mathrm{Med})$ Infección del carbunco. \\
\hline
\end{tabular}


En este sentido, cabe destacar que la precisión ha llevado a los autores del diccionario a matizar un buen número de definiciones siguiendo un patrón. Por ejemplo, la mayoría de los términos que en la primera edición se definieron con el hiperónimo «tratamiento», «método» o «terapia» se explican ahora con el sintagma «tratamiento terapéutico» (antibioterapia, crenoterapia, electroterapia, fangoterapia, hormonoterapia, mesoterapia, etc.), lo que no impide que el afán de exactitud y concreción conlleve otras matizaciones (cf. ventiloterapia). En las definiciones de los adjetivos que se explicaron mediante el modelo «De(l)...» o «De (la)...» seguido del nombre de la enfermedad o dolencia a la que hacen relación, se ha añadido el sintagma «o que la implica» (afásico, artrítico, artrósico, aterosclerótico, psicopático, seborreico, tofoso). Cuando el nombre contiguo a «De(l)...» o «De (la)...» refiere una rama de la medicina, se ha añadido «o de su objeto» (andrológico, angiológico, dermatológico, fisiopatológico, nosográfico, odontológico, oftalmológico, podológico, proctológico, etc.).

TABLA 5

Búsqueda de exactitud en la definición

\begin{tabular}{|c|c|c|}
\hline TÉRMINOS & DEFINICIÓN 1. ${ }^{\mathrm{a}}$ ed. & DEFINICIÓN 2.a ed. \\
\hline antibioterapia $f$ & $\begin{array}{l}\text { (Med) Tratamiento con } \\
\text { antibióticos. }\end{array}$ & (Med) Tratamiento terapéutico con antibióticos \\
\hline crioterapia $f$ & $\begin{array}{l}\text { (Med) Método curativo basado } \\
\text { en la aplicación de temperaturas } \\
\text { muy bajas. }\end{array}$ & $\begin{array}{l}\text { (Med) Tratamiento terapéutico basado en la } \\
\text { aplicación de temperaturas muy bajas. }\end{array}$ \\
\hline ventiloterapia $f$ & (Med) Terapia ventilatoria. & $\begin{array}{l}\text { (Med) Tratamiento terapéutico mediante } \\
\text { ventilación asistida. }\end{array}$ \\
\hline artrítico-ca adj & (Med) De (la) artritis. & (Med) De (la) artritis o que la implica. \\
\hline tofoso -sa adj & (Med) Que tiene o implica tofos. & $\begin{array}{l}\text { (Med) De (los) tofos o que los implica. } 2 \text { Que } \\
\text { tiene tofos. }\end{array}$ \\
\hline urológico -ca adj & (Med) De la urología. & (Med) De la urología o de su objeto. \\
\hline venereológico-ca $a d$ & & Mo \\
\hline
\end{tabular}

En segundo lugar, los cambios en la microestructura pueden estar motivados por el afán de claridad y por la necesidad de que en la definición no se emplee un léxico demasiado técnico, que obligue a la consulta de otras voces dentro o fuera del diccionario. Así, en la definición de aerofagia, se ha sustituido el adjetivo «espasmódica» por la paráfrasis relativa «que provoca eructos»; en la microestructura de anafrodisíaco $-c a$ se ha sustituido el adjetivo «venéreo» por «sexual»; en la explicación de analgesia «abolición» se ha cambiado por «supresión o disminución», etc. En la siguiente tabla se presentan algunos ejemplos. 
TABLA 6

Afán de claridad

\begin{tabular}{|c|c|c|}
\hline TÉRMINOS & DEFINICIÓN 1. a ed. & DEFINICIÓN 2. ${ }^{\mathrm{a}}$ ed. \\
\hline aerofagia $f$ & (Med) Deglución espasmódica de aire & (Med) Deglución de aire, que provoca eructos. \\
\hline $\begin{array}{l}\text { anafrodisíaco }-\mathrm{ca} \quad(t b \\
\text { anafrodisiaco) } a d j\end{array}$ & $\begin{array}{l}\text { (Med) Que disminuye o suprime el } \\
\text { apetito venéreo. } T b . n . m \text {., referido a } \\
\text { sustancia. }\end{array}$ & $\begin{array}{l}\text { (Med) Que disminuye o suprime el apetito sexual. } \\
\text { Tb. n. m., referido a sustancia o agente }\end{array}$ \\
\hline analgesia $f$ & $\begin{array}{l}\text { (Med) Abolición de la sensibilidad al } \\
\text { dolor. }\end{array}$ & $\begin{array}{l}\text { (Med) Supresión o disminución de la sensibilidad } \\
\text { al dolor. }\end{array}$ \\
\hline antiviral adj & (Med) Antivírico. & $\begin{array}{l}\text { (Med) Que impide el desarrollo de los virus. } T b n \\
m \text {, referido a medicamento o agente. }\end{array}$ \\
\hline arteriografía $f$ & (Med) Radiografía de las arterias. & $\begin{array}{l}\text { (Med) Procedimiento que permite la visualización } \\
\text { de las arterias, esp. por rayos X o resonancia } \\
\text { magnética. Frec la imagen asi obtenida. }\end{array}$ \\
\hline flebografía $f$ & $\begin{array}{l}\text { (Med) Registro del pulso venoso } \\
\text { mediante el flebógrafo. }\end{array}$ & $\begin{array}{l}\text { (Med) Radiografía de las venas y registro del } \\
\text { pulso venoso. }\end{array}$ \\
\hline
\end{tabular}

Pero, en ocasiones, ocurre lo contrario: la definición contiene el tecnicismo, esto es, la palabra más precisa y adecuada para explicar el término, la más usada por los expertos, porque las definiciones de tecnicismos de los diccionarios generales de lengua están tomadas de definiciones científicas, pero esta palabra no es la más sencilla ni la más frecuente ni la más conocida por la mayoría de los hablantes. En esos casos, los lexicógrafos se sirven de varios procedimientos para facilitar la comprensión del usuario: la definición adopta la forma de enunciado disyuntivo y la conjunción $o$ introduce la explicación del tecnicismo (antidiurético) o la explicación del tecnicismo se encierra entre paréntesis (sanioso):

TABLA 7

Uso de tecnicismos en la definición

\begin{tabular}{lll}
\hline TÉRMINOS & DEFINICIÓN 1. ${ }^{\mathrm{a}}$ ed. & DEFINICIÓN 2. ${ }^{\mathrm{a}}$ ed. \\
\hline antidiurético -ca adj & $\begin{array}{l}\text { (Med) Que impide la formación de } \\
\text { orina. }\end{array}$ & $\begin{array}{l}\text { (Med) Que impide la diuresis o formación de orina. Tb } \\
n . \text { m. referido a medicamento o agente }\end{array}$ \\
\hline sanioso -sa adj & $($ Med $)$ De(l) icor. & (Med) De(l) icor (líquido fétido de una llaga o úlcera). \\
\hline
\end{tabular}


Pero, en ocasiones, ocurre lo contrario: la definición contiene el tecnicismo, esto es, la palabra más precisa y adecuada para explicar el término, la más usada por los expertos, porque las definiciones de tecnicismos de los diccionarios generales de lengua están tomadas de definiciones científicas, pero esta palabra no es la más sencilla ni la más frecuente ni la más conocida por la mayoría de los hablantes. En esos casos, los lexicógrafos se sirven de varios procedimientos para facilitar la comprensión del usuario: la definición adopta la forma de enunciado disyuntivo y la conjunción $o$ introduce la explicación del tecnicismo (antidiurético) o la explicación del tecnicismo se encierra entre paréntesis (sanioso):

La necesidad de actualizar el léxico de la medicina y de reflejar las preferencias terminológicas de los profesionales de las ciencias de la salud y de los usuarios en general son otras razones para modificar el contenido de las definiciones. Dipsómano -na ha remplazado en el uso al adjetivo dipsomaníaco - ca y eso se refleja en los diccionarios proporcionando la explicación del término en el artículo correspondiente al término preferido por los profesionales y por los usuarios. Algunos ejemplos son:

TABLA 8

Predilección por otros términos

\begin{tabular}{|c|c|c|}
\hline TÉRMINOS & DEFINICIÓN 1. ed. & DEFINICIÓN 2. ${ }^{\mathrm{a}}$ ed. \\
\hline $\begin{array}{l}\text { dipsomaníaco -ca }(t b \\
\text { dipsomaniaco } a d j\end{array}$ & (Med) Que padece dipsomanía. $T b n$. & (Med) Dipsómano. $T b n$. \\
\hline dipsómano -na adj & (Med) Dipsomaníaco. $T b n$. & (Med) Que padece dipsomanía. $T b n$. \\
\hline antiviral $a d j$ & (Med) Antivírico. & $\begin{array}{l}\text { (Med) Que impide el desarrollo de los } \\
\text { virus. } T b n \text { m, referido a medicamento } \\
\text { o agente. }\end{array}$ \\
\hline antivírico-ca adj. / n. m. & $\begin{array}{l}\text { (Med) Que impide el desarrollo de } \\
\text { los virus. También n. m., referido a } \\
\text { medicamento o agente. }\end{array}$ & (Med) Antiviral. \\
\hline mastoplastia $f$ & (Med) Cirugía plástica de la mama ${ }^{1}$. & (Med) Mamoplastia. \\
\hline antitusígeno -na adj & (Med) Que evita la aparición de la tos. & (Med) Antitusivo. \\
\hline distress $m$ & $\begin{array}{l}\text { (Med) Problema. Gralm en la constr } \sim \\
\text { respiratorio. }\end{array}$ & (Med) Distrés. \\
\hline
\end{tabular}

Otros cambios observados en la microestructura no afectan directamente a la explicación en sí del término, sino a otras informaciones que afectan al contorno definitorio, que se incluye entre corchetes al principio de la definición, o a los distintos grados de limitación en el uso del término. Así, en algunas ocasiones, se ha suprimido el contorno porque interesa advertir «no la generalidad, sino la relativa frecuencia de la limitación en el uso», para ello la indicación se facilita tras la definición, en letra cursiva (analéptico), incluso, en algunas acepciones, se ha concretado más la limitación en el uso (anafrodisíaco). Sin embargo, hay ocasiones en las que el contorno se precisa más (mecánico) o se mantiene igual que en la $1 .^{a}$ edición pero se añade la advertencia sobre la limitación en su uso (antirrábico).

Por otro lado, si un uso figurado o metafórico se ha independizado respecto al sentido definido, se ha suprimido la nota «también figurado» y se ha añadido, en la mayor parte de los casos, la marca «literario» (álalo). 
TABLA 9

Información sobre la limitación en el uso

\begin{tabular}{|c|c|c|}
\hline TÉRMINOS & DEFINICIÓN 1.a ed. & DEFINICIÓN 2. ${ }^{\mathrm{a}}$ ed. \\
\hline (tb alalo) adj & $\begin{array}{l}(\mathrm{Med}) \text { Que padece alalia. Tb fig, fuera del } \\
\text { ámbito técn. }\end{array}$ & (Med o lit) Que padece alalia. \\
\hline $\begin{array}{l}\text { anafrodisíaco }-\mathrm{ca} \quad(t b \\
\text { anafrodisiaco) } a d j\end{array}$ & $\begin{array}{l}(\mathrm{Med}) \text { Que disminuye o suprime el apetito } \\
\text { venéreo. } T b . n . m . \text {, referido a sustancia. }\end{array}$ & $\begin{array}{l}(\mathrm{Med}) \text { Que disminuye o suprime el apetito } \\
\text { sexual. Tb. n. m., referido a sustancia o } \\
\text { agente }\end{array}$ \\
\hline -ca adj & $\begin{array}{l}(\mathrm{Med}) \text { [Medicamento] que sirve para restaurar } \\
\text { o estimular las fuerzas. } T b n \text {. }\end{array}$ & $\begin{array}{l}(\mathrm{Med}) \text { Que restaura o estimula las fuerzas. } \\
T b n \mathrm{~m} \text {, referido a medicamento. }\end{array}$ \\
\hline antirrábico-ca adj & $\begin{array}{l}(\mathrm{Med})[\mathrm{Cosa} \text {, especialmente vacuna] destinada } \\
\text { a prevenir la rabia. }\end{array}$ & $\begin{array}{l}(\mathrm{Med}) \text { [Cosa, especialmente vacuna }] \\
\text { destinada a prevenir la rabia. Tb } n \mathrm{~m} \text {, } \\
\text { referido a medicamento o remedio. }\end{array}$ \\
\hline mecánico-ca adj & $\begin{array}{l}4(\mathrm{Med}) \text { [Asfixia] causada por obstrucción } \\
\text { interna o externa de las vías respiratorias }\end{array}$ & $\begin{array}{l}4(\mathrm{Med}) \text { [Obstrucción] debida a causas } \\
\text { físicas. }\end{array}$ \\
\hline antitumoral adj & (Med) Eficaz contra los tumores. & $\begin{array}{l}(\mathrm{Med}) \text { Eficaz contra los tumores. } T b n \mathrm{~m} \text {, } \\
\text { referido a medicamento o remedio. }\end{array}$ \\
\hline
\end{tabular}

Otras veces, la validación de nuevas entradas en la segunda edición induce a los cambios en el modelo y contenido definitorios. Así, la inclusión del artículo inmunodepresión ha provocado el cambio de definición de los términos inmunodepresor e inmunodeprimido; la presencia de alergología, neuroanatomista o sociopatía ha motivado el cambio de la explicación de alergólogo, neuroanatómico y sociópata, respectivamente.

TABLA 10

Cambios motivados por la inclusión de nuevos entradas

\begin{tabular}{|c|c|c|}
\hline TÉRMINOS & DEFINICIÓN 1. ${ }^{\mathrm{a}}$ ed. & DEFINICIÓN 2. ${ }^{\mathrm{a}}$ ed. \\
\hline inmunodepresión $f$ & No figura & $\begin{array}{l}\text { (Biol) Disminución de las reacciones de } \\
\text { inmunidad [2]. }\end{array}$ \\
\hline inmunodepresor -ra adj & $\begin{array}{l}(\mathrm{Med}) \text { [Fármaco] que atenúa o anula las } \\
\text { reacciones de inmunidad del organismo. } \\
T b n \mathrm{~m} \text {. }\end{array}$ & (Biol) Que produce inmunodepresión. $T b n \mathrm{~m}$. \\
\hline inmunodeprimido - da adj & $\begin{array}{l}(M e d) \text { Que padece deficiencia o atenuación } \\
\text { de las reacciones de inmunidad. } T b n \text {, } \\
\text { referido a pers. }\end{array}$ & $\begin{array}{l}\text { (Biol) Que presenta inmunodepresión. } T b n \text {, } \\
\text { referido a pers. }\end{array}$ \\
\hline Alergólogo -ga $m$ y $f$ & $\begin{array}{l}(\mathrm{Med}) \text { Especialista en enfermedades } \\
\text { alérgicas. }\end{array}$ & $(\mathrm{Med})$ Especialista en alergología. \\
\hline neuroanatómico - ca $m$ y $f$ & II 2 (Med) Especialista en neuroanatomía. & II $m$ y $f 2$ (Med) Neuroanatomista. \\
\hline sociópata $m$ y $f$ & $\begin{array}{l}\text { (Med) Enfermo mental caracterizado por } \\
\text { comportamientos contrarios a la sociedad. }\end{array}$ & $\begin{array}{l}\text { (Med) [Pers.] que padece una sociopatía. } \\
\text { Frec } n .\end{array}$ \\
\hline
\end{tabular}


Otra consecuencia de la lematización de términos nuevos es la redacción de definiciones sinonímicas o, mejor dicho, la presencia de nuevas remisiones en el diccionario.

TABLA 11

Remisiones

\begin{tabular}{|c|c|c|}
\hline TÉRMINOS & DEFINICIÓN 1. ${ }^{\mathrm{a}}$ ed. & DEFINICIÓN 2.a ed. \\
\hline carcinogenético -ca adj & (Med) Que produce cáncer. & (Med) Carcinogénico. \\
\hline apopléjico-ca adj & $\begin{array}{l}\text { De la apoplejía. 2. Que padece } \\
\text { apoplejía. } T b n \text {. }\end{array}$ & (Med) Apoplético. \\
\hline distress $m$ & $\begin{array}{l}\text { (Med) Problema. Gralm en la constr } \\
\sim \text { respiratorio. }\end{array}$ & (Med) Distrés. \\
\hline
\end{tabular}

\subsubsection{Cambios en la marcación de voces}

No debe extrañar el número tan elevado de entradas que han experimentado modificación en su marcación en la segunda edición, en concreto 145 ( $v i d$. Anexo V), porque uno de los aspectos más controvertidos de la lexicografía y que conlleva gran dificultad es la marcación de los términos en los diccionarios generales (vid. Olaeta y Cundín 2011: CII-CXI, donde se reflexiona sobre la disparidad de criterios a la hora de marcar técnicamente las voces). Los autores del DEA advierten:

Solo empleamos las etiquetas de ámbitos especiales cuando el término en cuestión pertenece primordialmente a los especialistas. Prescindimos de la etiqueta cuando el término ha pasado al dominio general, aunque solo sea al nivel culto [...] En algún caso, sin embargo, la marca sirve para situar al lector en el ámbito preciso para entender la definición [...] (DEA: Guía del Lector, XVIII)

A pesar de las palabras de esta cita, hallamos muchos términos que pertenecen al español estándar y que se han marcado técnicamente, por ejemplo, infarto; por el contrario, figuran sin marcar voces que son propias de especialistas, como fiebre exantemática. Independientemente de la controversia en la marcación de voces técnicas en los diccionarios de lengua, las innovaciones observadas en la 2. a edición del DEA son las siguientes:

a) Añade la marca Med a 85 entradas. Según las palabras transcriptas más arriba en la «Guía del lector», las marcas se añaden cuando el término es de uso prácticamente exclusivo de los especialistas, es decir, formas, en muchos casos, hipercultas, que no han trascendido los límites del campo científico al que pertenecen. Pero, como se ha mencionado, hay otro tipo de entradas marcadas, aquellas cuya marca indica el nivel de lengua y su uso, es decir, la marca es indicativa de significado temático. Quizá esta sea la causa de que, en esta edición, se haya reconsiderado la marcación de un número tan elevado de términos, en concreto 50 sustantivos, 33 adjetivos, 1 prefijo y 1 locución.

Resulta llamativo que en la primera edición del DEA no se marcaran tecnicismos correspondientes a nombres de enfermedades o alteraciones que no forman parte del vocabulario común del público en general y que no pueden considerarse palabras comunes ni que hayan pasado al dominio general. Son los casos de dartros, actinomicosis, apoplejía, disosmia, kala-azar, lupus o priapismo, cuya marcación se lleva a cabo en esta segunda edición. 
Sin embargo, y atendiendo a la cita de la «Guía del lector», no deberían etiquetarse los términos que han pasado al dominio general; de hecho, en la primera edición, voces comunes del ámbito médico figuran sin marca, porque esas palabras no escapan a lo general y cotidiano: artrosis, mongolismo o tetraplejía son algunos ejemplos. El propio Manuel Seco (2003: 429) argumenta acerca de la marcación de tecnicismos lo siguiente:

En nuestro diccionario procuramos distinguir, mediante el empleo o no empleo de marcas, entre los tecnicismos que han entrado abiertamente en el uso general y los que, aunque tengan dentro de él alguna presencia, no dejan todavía de sentirse como propios de una especialidad. Voces como artrosis o infarto no llevarán, pues, ninguna marca de ámbito, ya que circulan hoy en la lengua común con la misma o quizá mayor frecuencia que reúma o ataque cardíaco. En cambio, leucemia linfoblástica (nombre que difundieron los periódicos para hablarnos de la enfermedad que padeció el tenor José Carreras) no podría desprenderse de la etiqueta «Medicina».

A pesar de lo reproducido en esta cita, el término infarto figura, como se ha mencionado, con marca medicina en las dos ediciones del diccionario; lo mismo sucede con el adjetivo reumatoide; por el contrario, reúma, reumático y reumatismo no llevan marca diatécnica; a artrosis, reumatología, reumatológico y reumatólogo se les añade la marca medicina en la 2. ${ }^{\text {a }}$ edición. Estos datos revelan la enorme dificultad para consignar la marcación de los términos de ámbitos especiales, puesto que, a pesar de que muchos de ellos han penetrado no solo en la lengua de hoy, sino también en el uso general, no pueden desprenderse de los lazos que los identifican como propios de una especialidad.

Quizás, con la finalidad de dotar de congruencia y uniformidad a la marcación de los artículos lexicográficos, la marca de especialidad se ha añadido a términos de la misma familia léxica, en concreto los que denotan una especialidad médica determinada, el especialista en esa rama y el adjetivo relacional correspondiente; así, pues, se ha añadido marca a: cancerología, cancerológico y cancerólogo; dermatología, dermatológico y dermatólogo; odontología, odontológico y odontólogo; otorrinolaringología, otorrinolaringológico y otorrinolaringólogo; podología, podológico y podólogo; radiología, radiológico y radiólogo; reumatología, reumatológico y reumatólogo, urología, urológico y urólogo. En ocasiones, el término que denota la rama de la medicina, por su propia especificidad, ya figuraba marcado en la $1 .{ }^{a}$ edición. Por ejemplo, psicogeriatría, malariología o estomatología se acompañaban de la marca medicina, pero esta no se adjuntaba a psicogeriatra, malariólogo o estomatólogo. En la edición de 2011, endemia se adscribe al campo de la medicina y endémico, no; enfermable, sí, pero enfermante, no, etc.

Se ha colocado marca a algunos adjetivos que se aplican a ciertos remedios o medicamentos, eficaces para combatir determinadas enfermedades y que nos remiten al ámbito de la medicina, por ejemplo, antifebril, antigangrenoso, antihistérico o antipalúdico; también se han marcado los adjetivos relacionales que se corresponden con determinada enfermedad o con la persona que la padece: arteriosclerótico, eccematoso, escrofuloso, gotoso o silicótico son una muestra de lo que decimos. Se observa, pues, que en la edición actual, se ha reducido la falta de sistematicidad para marcar unos términos sí $\mathrm{y}$ otros no; sin embargo, sigue sin entenderse que endemia figure con marca y endémico, no; tampoco llevan marca epilepsia ni epiléptico, pero sí la llevan epileptiforme y epileptoide.

b) Las innovaciones en la marcación pueden afectar a todo el artículo lexicográfico o solo a una acepción. Se consigna la marca en todos los sentidos de algunos artículos que, en la primera edición, solo la llevaban en la primera acepción. Son los casos de amiloide, cretínico, criptorquídico, maníaco, priapismo o saburroso. Sin embargo, en otras entradas no se sigue el mismo criterio y la marca diatécnica solo se incluye en una acepción, independientemente de la estrecha relación del resto de los sentidos con el ámbito de la medicina (meningítico, patología, patológico). No se entiende que términos de la misma familia léxica, no marcados 
en la primera edición, tal es el caso de patología, patológicamente, patológico y patólogo, consignen la marca, en la edición de 2011, en unas acepciones sí y en otras, no:

TABLA 12

Marcación de acepciones

\begin{tabular}{|c|c|c|}
\hline TÉRMINO & 1. ${ }^{a}$ EDICIÓN & 2. ${ }^{a}$ EDICIÓN \\
\hline priapismo $m$ & $\begin{array}{l}\text { (Med) Erección anormal y gralm. dolorosa } \\
\text { del pene sin apetito venéreo. } 2 \text { Exaltación } \\
\text { exagerada del impulso sexual en el hombre. }\end{array}$ & $\begin{array}{l}\text { (Med) Erección anormal y gralm. dolorosa } \\
\text { del pene sin apetito venéreo. } 2 \text { (Med) } \\
\text { Exaltación exagerada del impulso sexual } \\
\text { en el hombre. }\end{array}$ \\
\hline maníaco -ca ( $t b$ maniaco) adj & (Med) 1 De (la) manía. 2 Que padece manía & $\begin{array}{l}\text { (Med). De (la) manía. } 2 \text { (Med) Que padece } \\
\text { manía }\end{array}$ \\
\hline meningítico -ca $a d j$ & $\begin{array}{l}\text { (Med) De (la) meningitis. } 2 \text { [Pers.l que padece } \\
\text { meningitis. Tb n. b) [Pers.] que presenta } \\
\text { secuelas de haber padecido meningitis. Tb } \\
\text { n. Frec fig, aludiendo a deficiencia mental. }\end{array}$ & $\begin{array}{l}\text { (Med) De (la) meningitis.2 (Med) [Pers.1 } \\
\text { que padece meningitis. Tb } n \text {. b) [Pers.] } \\
\text { que presenta secuelas de haber padecido } \\
\text { meningitis. Tb } n \text {. Frec fig, aludiendo a } \\
\text { deficiencia mental. }\end{array}$ \\
\hline patología $f$ & $\begin{array}{l}\text { Estudio de las enfermedades y de los } \\
\text { trastornos que causan en el organismo. b) } \\
\text { Conjunto de enfermedades o trastornos [de } \\
\text { alguien o algo]. }\end{array}$ & $\begin{array}{l}\text { (Med) Estudio de las enfermedades y de } \\
\text { los trastornos que causan en el organismo. } \\
\text { b) Conjunto de enfermedades o trastornos } \\
\text { [de alguien o algo]. c) Enfermedad. }\end{array}$ \\
\hline
\end{tabular}

c) Muchos ámbitos de la ciencia están íntimamente relacionados de ahí que surja la dificultad de adscribir algunos términos a un único campo científico. La fisiología, la anatomía, la psicología, etc., no pueden desligarse de la medicina, y, por consiguiente, en algunos términos a la ya consignada marca «medicina» se añade otra: «fisiología» en vasoconstricción, vasoconstrictor, vasodepresor, vasodilatación, vasodilatador, vasomotor; «botánica» en vicariante. O bien que consignada una marca, por ejemplo «anatomía», se le añade la marca «medicina»: linfocítico.

d) La marcación de términos, aunque es bastante sistemática (habitualmente se incluye tras el número que indica la acepción y delante de la información semántica sobre la entrada), no sigue un procedimiento único. En los lemas angina de pecho y palpación, hallamos referencias al ámbito de especialidad en el interior de la entrada: la marca se consigna al final, tras la explicación del término:

angina de pecho $\mathrm{f}$ Síndrome debido a una insuficiencia coronaria, que se manifiesta por un dolor agudo en el pecho y una intensa sensación de angustia. $\mathrm{Tb}$ (Med) simplemente angina.

palpación f Acción de palpar [1]. Esp en Med.

e) En ocasiones, junto a la marca diatécnica, se proporciona información sobre los niveles de uso o sobre la vigencia de un término concreto. Respecto de la 
marcación diacrónica, en el repertorio de abreviaturas, este diccionario incluye la marca «histórico» (hist) para indicar que un término concreto nombra una realidad del pasado. De esta manera, los términos vómito negro o vómito prieto, que se usaban en los siglos XVIII y XIX como sinónimos de fiebre amarilla unas veces, y de vómito atrabiliario o de bilis negra, otras, llevan la marca «histórico» (Vid. Hurtado de Mendoza 1823: 937). El DTM incluye únicamente la forma vómito negro con marca coloquial.

Otro rasgo de la marcación diacrónica la hallamos en las etiquetas «hoy raro» y «raro»; la primera indica que el término era usual al principio de la época estudiada, pero posteriormente ha caído en desuso; son los casos de curieterapia y organoterapia. La marca «raro» acompaña a términos que habían dejado de usarse, pero que conscientemente sacan a flote escritores o investigadores por gusto personal. En esta edición se ha añadido a roentgenografía 'radiografía', y a roentgenoterapia y roengenterapia 'radioterapia'.

El registro lingüístico de los términos también se consigna junto a la marca medicina. Así, en la segunda edición del diccionario, se ha restringido el nivel de comunicación de algunos términos con la marca «literario», enmarcándolos en niveles más propios de la lengua escrita que de la hablada. Esta etiqueta se ha añadido a álalo y alálico, términos que, si los excluimos del ámbito técnico, son propios del lenguaje culto, elevado y esmerado. Por el contrario, se ha cambiado la marca «literario» por «medicina» en el artículo correspondiente al término priápico, indicando con ello que no suele usarse fuera del tecnolecto correspondiente.

f) La jerarquía de las marcas en los diccionarios ha sido estudiada por diferentes lexicógrafos y todos ellos dan cuenta de la incongruencia existente respecto a la categoría de las marcas. Además de «medicina», las abreviaturas usadas en DEA, para acompañar a términos que, de alguna manera, están relacionados con el ámbito de la medicina y ciencias de la salud son «anatomía», «biología», «ciencias naturales», «farmacia», «fisiología», «óptica», «psicología», «química» y «veterinaria». La dificultad para discernir lo que es propio única y exclusivamente del ámbito de la medicina de lo que se puede adscribir a otros campos científicos más específicos ha motivado algunos cambios en la etiqueta de las voces o la inclusión de dos marcas relacionadas con la medicina, por ejemplo, linfocítico se etiqueta con «anatomía» o «medicina»y virosis con «biología» y «medicina». Los cambios en la marcación atienden a la siguiente tipología:

Se cambia la marca «medicina» por «psicología» en: acrofobia, antropofobia, aerofobia, agorafobia, biotípico, eritrofobia, profundo, reflexología (2. acep.), tanatofilia y transferencia.

- Se cambia la marca «medicina» por «biología» en: inmune, inmunidad, inmunitario, inmunización, inmunizador, inmunizante, inmunizar, inmunodeficiente, inmunodepresor, inmunodeprimido, inmunofluorescencia, inmunógeno, inmunohematología, inmunología, inmunológico, inmunólogo, inmunoprecipitación, inmunosupresión e inmunosupresor.

- $\quad$ Se cambia «medicina» por «fisiología» en: plaquetario y premenstrual.

- $\quad$ Se cambia «medicina» por «anatomía» en: pleuropulmonar y rectal.

- $\quad$ Se cambia «fisiología» por «medicina» en: linfa (2. ${ }^{\mathrm{a}}$ acep.)

g) Por último, las innovaciones en la marcación afectan a la eliminación de la marca «medicina» en la entrada lámpara de cuarzo, a pesar de que entre sus definidores se encuentran voces que 
remiten al ámbito de la medicina: lámpara de cuarzo 'dispositivo para la aplicación terapéutica de rayos ultravioletas'. Por otro lado, se suprime la marca «veterinaria» que figuraba junto a «medicina» en susceptible.

\section{Eliminación de artículos}

La renovación del diccionario también comprende la eliminación, por diversas causas, de una serie de artículos (vid. Anexo VI). En la «Nota para la segunda edición» (DEA 2011: XVI) se hace referencia a los cambios más significativos que afectan no solo a la supresión de voces, sino también a la del nombre del autor en las citas de prensa y que, según los propios autores, se ha debido para mantener, para mayor comodidad de manejo, los dos volúmenes. En cuanto a la eliminación de entradas, se mencionan los casos de los adverbios acabados en - mente y de los adjetivos y nombres gentilicios.

Por lo que respecta al ámbito de la medicina se han eliminado ventisiete entradas, trece corresponden a adverbios terminados en -mente; seis, a sustantivos y ocho, a adjetivos, sobre todo relacionales.

\subsection{Adverbios}

Los trece adverbios acabados en -mente que se validaron con marca medicina en la primera edición se han eliminado como artículos lexicográficos independientes. La mayoría de ellos (once, en concreto) se incluyen en el artículo lexicográfico del adjetivo correspondiente, reducidos a la «simple mención (en la forma || x-mente $a d v)$ »(DEA, 2011: XVI). Son los casos de arrítmicamente, diagnósticamente, endovenosamente, epidemiológicamente, farmacológicamente, hemodinámicamente, inmunológicamente, intramuscularmente, intrauterinamente, profilácticamente $\mathrm{y}$ tetánicamente. Otros, simplemente, no se validan de ninguna manera. No hay mención alguna al adverbio sintomatológicamente, puesto que no se incluye en la entrada sintomatológico $-c a$. Por el contrario, figura en la entrada sintomático $-c a$, sin marca alguna, el adverbio sintomáticamente. Por último, el adverbio subcutáneamente, que se etiquetó con marca «medicina» en la primera edición, se ha incluido en la entrada subcutáneo $-a$, adscrito al ámbito de la «anatomía».

\subsection{Sustantivos}

Los seis sustantivos excluidos en la nueva edición son: criogenina, ergoftalmología, ileus, inmunopatología, inmunoterapia y situs. Creemos, sin temor a equivocarnos, que la exclusión de estos términos del diccionario se debe al afán por recoger el léxico vivo «a partir de la realidad comprobada del uso de la lengua» $\mathrm{y}$, evidentemente, algunos de estos términos han perdido vigencia y otros han quedado reducidos a situaciones comunicativas entre profesionales de la medicina.

Criogenina 'antitérmico empleado en la tuberculosis', ergoftalmología 'especialidad de la oftalmología que estudia los problemas del ojo en relación con el trabajo', inmunopatología 'estudio de las respuestas de inmunidad asociadas con la enfermedad' e inmunoterapia 'tratamiento de las enfermedades infecciosas por la producción de inmunidad' son términos que se utilizaron muy a menudo durante algunos años, pero que en la actualidad han caído en desuso. No se han incluido en el DTM y figuran, exclusivamente, en obras médicas ultraespecializadas y en glosarios relacionados con las enfermedades a las que hacen referencia. De ahí su exclusión del diccionario.

Ileus 'oclusión intestinal' y situs 'sitio, lugar' son latinismos que, por influencia del inglés, se utilizaron, ocasionalmente, en la literatura médica en castellano, el primero acompañado, frecuentemente, por un adjetivo (ileus dinámico, ileus paralítico, ileus mecánico). En nuestra lengua, el término preferido ha sido íleo. En cuanto a situs, los diccionarios especializados no lo lematizan como término simple, sino que figura siempre acompañado de 
un complemento especificador: situs inversus, situs solitus, situs transversus.

\subsection{Adjetivos}

De la categoría de adjetivo se han eliminado ocho términos. En unos casos, la eliminación ha sido completa, esto es, no quedan rastros en el diccionario, como es el caso de abiotrófico $-c a$; en otros casos, el término en cuestión ha sido sustituido por otro de uso más habitual, por ejemplo, en lugar de esteatópigo - ga hallamos esteatopigio - gia, con la marca de «especialidades varias»; asimismo, se ha prescindido de algunos adjetivos relacionales, pues los sustantivos a los que hacían referencia también se han eliminado (inmunoterápico $-c a)$ o su presencia no tiene sentido porque hacen referencia a una marca registrada (novocaínico-ca).

En la primera edición del DEA se incluyó el adjetivo esteatópigo - ga, con marca medicina, pero como se puede leer en Olaeta y Cundín (2011: XVI-XVII) se consignan con la etiqueta medicina una serie de artículos cuya lematización es controvertida o, al menos, dudosa, pues no se ha hallado documentación científica donde se vincule el adjetivo con el ámbito de la medicina. Los textos donde habitualmente se incluye el adjetivo pertenecen a obras o documentos relacionados con la historia del Arte, de ahí que se concluyera que la marcación de este adjetivo debería reconsiderarse. Pues bien, en la 2. edición se elimina esta entrada y, en su lugar, se lematiza el término esteatopigio -gia, con la marca «especialidades varias» y con el sentido de 'Que presenta esteatopigia [Desarrollo excesivo del tejido adiposo en las nalgas]'.

\section{Conclusiones}

1. La frecuencia de aparición del léxico médico, sobre todo gracias a la labor divulgativa de los medios de comunicación, ha propiciado el aumento del número de artículos lexicográficos del ámbito de las ciencias de la salud en los diccionarios generales de lengua. En este sentido, DEA es el diccionario más innovador, pues si en la edición de 1999 realiza una selección mayor de vocabulario técnico que el resto de diccionarios de uso, en esta edición, la cifra aumenta considerablemente: doscientas cuarenta y siete nuevas entradas y tres sublemas. Aunque no encontramos en el prólogo justificación explícita en relación a los lemas especializados incorporados, se puede aseverar que están en estrecha relación con las demandas de la sociedad o con los avances científicos y técnicos, pues la mayoría de los términos refieren prácticas quirúrgicas, relacionadas con la cirugía estética, muy populares en los últimos años, con aparatos diseñados para llevar a cabo pruebas diagnósticas $\mathrm{y}$ terapéuticas, o procedimientos terapéuticos nuevos, o enfermedades y dolencias antes inauditas, etc.

2. La mayoría de las voces incorporadas están formadas por pseudoprefijos y pseudosufijos, de origen griego, muy frecuentes en el ámbito de la medicina, aunque no faltan voces de procedentes de otras lenguas ni las formadas por sufijos propios del lenguaje común. Los verbos lematizados no suelen consignarse en los diccionarios especializados.

3. La mayoría de definiciones son conceptuales; la definición sinonímica se emplea muy poco estableciendo diferentes tipos de relación entre los términos definidos: a) el término especializado se define con una palabra del lenguaje no especializado; b) el término no especializado se define con un tecnicismo; c) el término especializado se define con otro término especializado; d) el término remite a otra variante gráfica.

4. Debido a procesos polisémicos y de extensión de significado se ha completado la microestructura de algunos artículos 
con acepciones nuevas, si bien la inclusión de algunas acepciones puede ser polémica (cacosmia 'halitosis'). Muchas de las nuevas acepciones son propias de adjetivos relacionales, aunque no faltan las propias de otras categorías gramaticales creadas por distintos procedimientos trópicos.

No obstante, se mantiene sin modificación alguna, con respecto a la primera edición, la información de ciertos artículos correspondientes a términos que han perdido su primitivo sentido o este ha quedado desplazado en el uso con respecto a otros usos más actuales (explantar, titilar, tanatofilia), por lo que debería replantearse la inclusión de otras acepciones.

5. Respecto del contenido de la microestructura, se observan dos innovaciones principales: las que afectan a la explicación del término y las relacionadas con informaciones gramaticales o de niveles de uso del término. Así, cabe destacar el aumento de definiciones sinonímicas, o mejor dicho de remisiones, debido, sin lugar a dudas, a la inclusión de nuevas entradas y a la necesidad de evitar la repetición de la misma información en más de un artículo lexicográfico, para facilitar el manejo del diccionario en dos volúmenes.

Otros cambios pueden estar motivados por el afán de claridad, pues las definiciones no están redactadas para los técnicos o especialistas, sino para los "hablantes comunes", de ahí la búsqueda de definidores sencillos y precisos, pero la dificultad de conciliar precisión y claridad lleva a la inclusión de tecnicismos entre los definidores. En esos casos, los autores se han servido de varios procedimientos para facilitar la comprensión de los usuarios (antidiurético, sanioso).

6. A través del estudio de la marca «medicina» se ha podido observar el ingente esfuerzo realizado por aunar criterios a la hora de colocar las marcas a un término o a una acepción, y, en la edición aumentada, ha aumentado considerablemente el número de acepciones especializadas con marca temática. En este sentido, se ha añadido la marca «medicina» a casi un centenar de términos o acepciones que no la incluían en la edición anterior. Grosso modo se observa que se pueden encontrar dos tipos de entradas marcadas: por un lado, las formas hipercultas y aquellas de uso exclusivo entre los profesionales de la medicina (dartros, actinomicosis, kala-azar o priapismo) y, por otro lado, aquellos términos cuya marca indica el nivel de lengua y su uso, es decir, la marca aporta un significado temático, indica que la definición de este término implica la pertenencia a un campo concreto, y que el uso del término está ligado a un dominio concreto (artrosis, infarto). Aun así, en la introducción de la obra, deberían figurar los criterios de marcación de los términos, pues no se entiende, por ejemplo, cuál es la razón por la que endemia figura con marca y endémico, sin ella, cuando, por lo que respecta a la marca «medicina», esta se ha añadido a un elevado porcentaje de adjetivos relacionales.

7. Se ha modificado la marcación de algunos términos y acepciones. La dificultad que conlleva en numerosas ocasiones adscribir un término a un ámbito científico concreto (no debemos olvidar que las fronteras entre algunas ciencias no son nítidas y es evidente la interrelación entre ellas) es lo que ha motivado el cambio de marca de algunos términos, sobre todo, el cambio de la marca «medicina» por «psicología» o por «biología». Sin embargo, cuantitativamente hablando, el cambio más frecuente en la marcación diatécnica consiste en consignar la marca «medicina» a términos que no estaban adscritos a ningún ámbito en la primera edición. 


\section{Bibliografía}

Ahumada, Ignacio. 1989. Aspectos de lexicografía teórica. Aplicaciones al DRAE. Granada: Universidad de Granada.

Battaner, Paz (dir.). 2003. Diccionario de uso del español de América y España [versión electrónica]. Barcelona: Bibliograf. (VOX)

Calvet, Louis-Jean. 1980. Les sigles. Paris: PUF.

Gutiérrez Cuadrado, Juan (dir.). 1996. Diccionario Salamanca de la lengua española. Madrid: Santillana. (DSLE)

Gutiérrez Rodilla, Bertha M. 1998. La ciencia empieza en la palabra. Barcelona: Ediciones Península.

Hurtado de Mendoza, Manuel. 1823. Suplemento al Diccionario de medicina y cirugía del profesor D. Antonio Ballano. Madrid: Imprenta de Brugada.

Kocourec, Rostilav. $1991^{2}$. La langue française de la technique et de la science: vers une linguistique de la langue savante. Wiesbaden: Brandestetter Verlag.

Lang, Mervyn Franc. 1992. Formación de palabras en español. Madrid: Cátedra.

Maldonado, Concepción (dir.). 2000. Clave. Diccionario de uso del español actual, 7. ${ }^{\mathrm{a}}$ ed. Madrid: SM. (CLAVE)

Martínez de Sousa, José. 2004. Ortografía y ortotipografía del español actual. Gijón: Trea.

Mederos, Humberto. 1994. "A propósito de la definición lexicográfica". En Hernández Hernández, Humberto. Aspectos de lexicografía contemporánea. Barcelona: Bibliograf, pp. 95-106.
Moliner, María. 2007. Diccionario de uso del español. Madrid: Gredos. (DUE)

Nedobity, Wolfgang. 1981. "How to Cope with Abbreviated Terms and Designations". En TermNet News, 2-3, pp. 43-46.

Olaeta, Roberto y Margarita Cundín. 2011. Vocabulario médico. Con todas las voces recogidas en los diccionarios de uso. Bilbao: Itxaropena.

Petrecca, F. 1991. "Taxonomía lingüística y discurso lexicográfico". En Boletín de la Real Academia Española, LXXII (256), pp. 251-267.

Porto Dapena, José Álvaro. 2002. Manual de técnica lexicográfica. Madrid: Arco Libros.

Real Academia Española. 2001. Diccionario de la lengua española. 22. ed. Madrid: Espasa Calpe. (DRAE)

. 2009. Nueva gramática de la lengua española, vol. I Morfología y Sintaxis. Madrid: Espasa Calpe. (NGLE)

Real Academia Nacional de Medicina. 2011. Diccionario de términos médicos. Madrid: Médica Panamericana. (DTM)

Rebollo, Miguel A. 1991. “-Izar”. En Anuario de estudios filológicos. Cáceres: Universidad de Extremadura, pp. 405-411.

Seco, Manuel, Olivia Andrés y Gabino Ramos. 1999 y 2011. Diccionario del español actual. Madrid: Aguilar. (DEA)

Seco, Manuel. 2003. "El diccionario sincrónico del español". En Estudios de lexicografía española. Madrid: Gredos, pp. 417-438. 


\section{Anexos}

\section{ANEXO I}

Nuevas entradas en la edición de 2011

\begin{tabular}{|c|c|}
\hline VOCABLOS NUEVOS & DEFINICIÓN \\
\hline abdominoplastia $f$ & (Med) Cirugía plástica del abdomen, esp. para reducir la grasa. \\
\hline aclaramiento $m$ & (Med) Depuración. \\
\hline adinámico -ca adj & (Med) De (la) adinamia o que la implica. \\
\hline aerofágico -ca adj & (Med) De la aerofagia. 2 (Med) Que padece aerofagia. \\
\hline alergológico -ca adj & (Med) De (la) alergología o de su objeto. \\
\hline alexitimia $f$ & (Med) Incapacidad para identificar las emociones y expresarlas con palabras. \\
\hline alexitímico -ca adj & (Med) De (la) alexitimia. 2 (Med) Que padece alexitimia. $T b n$, referido a pers. \\
\hline algoterapia $f$ & (Med) Tratamiento terapéutico con algas. \\
\hline aloinjerto $m$ & (Med) Homoinjerto. \\
\hline alotrasplante $m$ & (Med) Homotrasplante. \\
\hline amiloideo $-\mathrm{a}$ & (Quim y Med) Amiloide. \\
\hline anafrodisia $f$ & (Med) Carencia o disminución del deseo sexual. \\
\hline angio- pref & (Med) De los vasos sanguíneos o linfáticos. \\
\hline angiógrafo $m$ & (Med) Aparato para realizar angiografías. \\
\hline aniridia $f$ & (Med) Falta congénita del iris del ojo. \\
\hline anósmico - ca adj & (Med) Que carece del sentido del olfato. \\
\hline ansiógeno -na adj & (Med) Que causa ansiedad. \\
\hline antiagregante $a d j$ & $\begin{array}{l}\text { (Med) Que impide la agregación de las plaquetas. } T b n \mathrm{~m} \text {, referido a sustancia o } \\
\text { medicamento. }\end{array}$ \\
\hline antiandrógeno -na adj & (Med) Que actúa contra los andrógenos. Frec $n \mathrm{~m}$, referido a medicamento o agente. \\
\hline antineoplásico -ca $a d j$ & $(\mathrm{Med})$ Antitumoral. $\mathrm{Tb} n$ \\
\hline antipsicótico -ca adj & (Med) Que combate la psicosis. $T b n \mathrm{~m}$, referido a medicamento o agente. \\
\hline antirretroviral adj & (Med) Que combate los retrovirus. Tb $n$ m, referido a medicamento. \\
\hline antroposófico - ca adj & $\begin{array}{l}2(\mathrm{Med}) \text { [Medicina] basada en la antroposofía, con una concepción integral del ser humano } \\
\text { y cuyo objetivo es apoyar al paciente para que sea capaz de restablecer su propio equilibrio. } \\
\text { b) }(\mathrm{Med}) \mathrm{De}(\mathrm{la}) \text { medicina antroposófica. }\end{array}$ \\
\hline apoptosis $f$ & (Med y Biol) Muerte celular programada. \\
\hline apoptótico -ca adj & (Med y Biol) De (la) apoptosis o que la implica. \\
\hline apraxia $f$ & $\begin{array}{l}\text { (Med) Incapacidad de realizar determinados movimientos voluntarios aunque exista capa- } \\
\text { cidad física para ello. }\end{array}$ \\
\hline aromaterapia $f$ & (Med) Tratamiento terapéutico con aceites esenciales aromáticos \\
\hline arteriográfico -ca adj & (Med) De (la) arteriografía. \\
\hline artroscopio $m$ & (Med) Instrumento para examinar el interior de las articulaciones. \\
\hline atopia $f$ & (Med) Predisposición hereditaria a sufrir diversas alergias. \\
\hline atópico -ca $a d j$ & (Med) De la atopía o causado por ella. 2 (Med) Que padece una enfermedad atópica. \\
\hline autorradiográfico -ca $a d j$ & (Med) De la autorradiografía. \\
\hline
\end{tabular}




\begin{tabular}{|c|c|}
\hline bacteriuria $f$ & (Med) Presencia de bacterias en la orina. \\
\hline bífidus $m$ & $\begin{array}{l}\text { (Med) Bacteria de la flora intestinal, que se incorpora como aditivo en diversos productos } \\
\text { lácteos (Bifidobacterium bifidus). }\end{array}$ \\
\hline bloqueante adj & (Med) Que bloquea. $T b n \mathrm{~m}$, referido a medicamento o agente. \\
\hline braquiterapia $f$ & $\begin{array}{l}\text { (Med) Radioterapia que consiste en insertar las fuentes de radiación en las cavidades del } \\
\text { cuerpo o directamente en el tumor. }\end{array}$ \\
\hline bruxismo $m$ & (Med) Rechinamiento involuntario de los dientes durante el sueño. \\
\hline cannabinoide adj & (Med) [Sustancia] derivada del cannabis utilizada en medicina. Frec $n$ m. \\
\hline ecocardiográfico - ca adj & (Med) De (la) ecocardiografía. \\
\hline carcinogénico -ca adj & (Med) De (la) carcinogénesis \\
\hline carcinomatosis $f$ & (Med) Afección de carcinomas diseminados por el cuerpo. \\
\hline carcinomatoso -sa adj & 1 (Med) De(1) carcinoma o que lo implica. 2 Afectado de cancer1. Tb n, referido a pers. \\
\hline cataplejía $f$ & Cataplexia. \\
\hline cataplexia $f$ & (Med y Vet) Perdida de tono muscular. \\
\hline cervico-pref & (Med) De(l) cuello \\
\hline chagas loc adj & $\begin{array}{l}\text { (tb con minúscula en acep 2) I loc adj } \mathbf{1} \text { de } \sim(\text { Med }) \text { [Enfermedad o mal] de carácter tropical } \\
\text { y gralm. crónico, causados por el Trypanosoma cruzi. } \\
\text { II } m \mathbf{2} \text { (Med) Enfermedad de Chagas. }\end{array}$ \\
\hline chocoterapia $f$ & (Med) Tratamiento terapéutico con chocolate. \\
\hline cinesiología $f$ & (Med) Quinesiología. \\
\hline cinesiológico -ca adj & (Med) Quinesiológico. \\
\hline colectomía $f$ & (Med) Extirpación quirúrgica del colon. \\
\hline colorterapia $f$ & $(\mathrm{Med})$ Cromoterapia. \\
\hline coprolálico -ca adj & (lit o Med) De (la) coprolalia o que la implica. 2 (lit o Med) Que padece coprolalia. Tb $n$. \\
\hline coronavirus $m$ & $\begin{array}{l}\text { (Med) Virus que provoca infecciones respiratorias y digestivas en el hombre y en los } \\
\text { animales (gén. Coronavirus). }\end{array}$ \\
\hline corticoterapia $f$ & (Med) Tratamiento terapéutico mediante corticoides. \\
\hline criogenizar tr & $\begin{array}{l}\text { (Med) Congelar [a un ser vivo] y mantenerlo a bajísimas temperaturas para una futura } \\
\text { reanimación. }\end{array}$ \\
\hline cromoterapia $f$ & $\begin{array}{l}\text { (Med) Tratamiento terapéutico basado en los efectos producidos por los colores en el } \\
\text { organismo. }\end{array}$ \\
\hline cureta $f$ & (Med) Instrumento utilizado para hacer curetajes o raspados. \\
\hline curetaje $m$ & (Med) Limpieza mediante raspado de una parte del cuerpo, esp. de una cavidad. \\
\hline delfinoterapia $f$ & (Med) Tratamiento terapéutico basado en los efectos producidos por el trato con los delfines. \\
\hline demenciación $f$ & (Med) Acción de demenciarse. Tb su efecto. \\
\hline demenciarse intr prl & (Med o lit) Pasar a sufrir demencia. Gralm en part, frec sustantivado, referido a pers. Tb fig. \\
\hline dializable adj & (Quím y Med) Que se puede dializar. \\
\hline dietoterapia $f$ & (Med) Tratamiento dietético. \\
\hline disfásico - ca adj & (Med) Que padece disfasia. $T b$ n. 2 (Med) De (la) disfasia o que la implica. \\
\hline distrés $m$ & $\begin{array}{l}\text { (Med) Problema o trastorno. Gralm en la constr } \sim \text { respiratorio. } 2 \text { (Med) Angustia moral. } \\
\text { Gralm en la constr } \sim \text { psicológico o moral. }\end{array}$ \\
\hline dolorímetro $m$ & (Med) Aparato para medir el dolor. \\
\hline ecocardiógrafo $m$ & (Med) Aparato para realizar ecocardiografías. \\
\hline ecolálico -ca adj & (Med o lit) De (la) ecolalia o que la implica. \\
\hline
\end{tabular}




\begin{tabular}{|c|c|}
\hline electromiográfico - ca adj & (Med) De(l) electromiógrafo. \\
\hline electromiograma $m$ & (Med) Gráfico obtenido por el electromiógrafo. \\
\hline encefalía $f$ & (Med) Encefalopatía. Gralm con el adj espongiforme ( ESPONGIFORME) \\
\hline encefalográfico -ca adj & (Med) De (la) encefalografía. \\
\hline encefalópata $m$ y $f$ & (Med) [Pers.] que padece una encefalopatía. Frec $n$. \\
\hline epidemiologista $m$ y $f$ & (Med, raro) Epidemiólogo. \\
\hline esclerosante $a d j$ & (Med) Que causa esclerosis. Tb (lit) fig, fuera del ámbito técn. \\
\hline escleroterapia $f$ & (Med) Tratamiento de las varices mediante inyecciones esclerosantes \\
\hline esfigmómetro $m$ & (Med) Esfigmógrafo. \\
\hline espirográfico -ca adj & (Med) De (la) espirografía. \\
\hline espirógrafo $m$ & (Med) Aparato para realizar espirografías. \\
\hline espongiforme $a d j$ & $\begin{array}{l}\text { (Med) [Encefalopatía o encefalitis] en que el cerebro adquiere aspecto esponjoso. } 2 \text { (Med) } \\
\text { Que padece encefalopatía espongiforme. Frec fig, con intención ponderativa, aludiendo a } \\
\text { la locura. }\end{array}$ \\
\hline estent $m$ & (Med) Stent. \\
\hline fascitis $m$ & (Med) Inflamacion de una fascia. \\
\hline feticida adj & (Med o Der) Que mata el feto. $T b n$, referido a pers. \\
\hline fibromialgia $f$ & (Med) Enfermedad caracterizada por dolores musculares y fatiga crónica. \\
\hline fibrosarcoma $m$ & (Med) Tumor maligno del tejido conjuntivo fibroso. \\
\hline fisiopatólogo -ga $m$ y $f$ & (Med) Especialista en fisiopatología. \\
\hline fisioterapista $a d j$ & (Med) De (la) fisioterapia. \\
\hline flebológico -ca adj & (Med) De (la) flebología o de su objeto. \\
\hline fotofóbico -ca adj & (Med) De (la) fotofobia o que la implica. 2 (Med) Fotófobo. $T b n$. \\
\hline frémito $m$ & 2 (Med) Estremecimiento o vibración. \\
\hline gastroplastia $f$ & (Med) Cirugía plástica del estómago, esp. para reducirlo. \\
\hline gemoterapia $f$ & (Med) Tratamiento terapéutico basado en las propiedades de las gemas u otros minerales. \\
\hline granulocitopenia $f$ & (Med) Escasez anormal del número de granulocitos en la sangre. \\
\hline granulocitosis $f$ & (Med) Aumento anormal del número de granulocitos en la sangre. \\
\hline háptico -ca adj & (Med o lit) Táctil. \\
\hline hematopatólogo -ga $m$ y $f$ & (Med) Especialista en hematopatología. \\
\hline hepatólogo -ga $m$ y $f$ & (Med) Especialista en hepatología. \\
\hline hiperplásico -ca adj & (Biol o Med) Que presenta hiperplasia. \\
\hline hipnoterapia $f$ & (Med) Tratamiento terapéutico por medio del hipnotismo. \\
\hline hipoplásico-ca adj & (Biol o Med) Que presenta hipoplasia. \\
\hline histeroscopia $f$ & $(M e d)$ Examen del interior del útero. \\
\hline homeoterapia $f$ & (Med) Homeopatía. \\
\hline ibuprofeno $m$ & (Med) Cierto ácido usado como antiinflamatorio, analgésico y antipirético. \\
\hline implantológico -ca adj & (Med) De (la) implantología o de su objeto. \\
\hline implantólogo -ga $m$ y $f$ & (Med) Especialista en implantología. \\
\hline inciso -sa adj & (Med y Arte) Hecho por incisión. \\
\hline intravascular $a d j$ & (Med) Que se produce o se coloca en el interior de un vaso sanguíneo. \\
\hline iridológico -ca adj & (Med) De (la) iridología o de su objeto. \\
\hline iridólogo -ga $m$ y $f$ & (Med) Especialista en iridología. \\
\hline
\end{tabular}




\begin{tabular}{|c|c|}
\hline laparoscopio $m$ & (Med) Instrumento que sirve para practicar la laparoscopia. \\
\hline laringólogo -ga $m$ y $f$ & (Med) Especialista en laringología. \\
\hline legionela $f$ & (Med) Legionella \\
\hline legionelosis $f$ & (Med) Enfermedad producida por la legionela. \\
\hline legra $f$ & (Med) Instrumento quirúrgico cortante, usado para raspar superficies óseas o mucosas. \\
\hline legrar $t r$ & (Med) Raspar con la legra [superficies óseas o mucosas]. \\
\hline lentigo $m$ & $\begin{array}{l}\text { (Med) Afección cutánea caracterizada por pequeñas manchas de color oscuro. Tb la misma } \\
\text { mancha. }\end{array}$ \\
\hline linfadenectomía $f$ & (Med) Ablación quirúrgica de los ganglios linfáticos [1] \\
\hline linfedema $m$ & (Med) Edema por obstrucción de un vaso linfático [1]. \\
\hline lipoatrofia $f$ & (Med) Atrofia del tejido adiposo. \\
\hline lipotímico -ca adj & (Med) De (la) lipotimia o que la implica. 2 (Med) Que padece lipotimia. $T b n$. \\
\hline logorreico -ca $a d j$ & $\begin{array}{l}\text { (lit o Med) De (la) logorrea o que la implica. } 2 \text { (lit o Med) Que padece logorrea. } T b \text { n, refe- } \\
\text { rido a pers. }\end{array}$ \\
\hline lumen $m$ & 2 (Med) Luz (área interior de la sección transversal de un conducto). \\
\hline luminoterapia $f$ & (Med) Fototerapia. \\
\hline mastectomizar $t r$ & (Med) Someter a mastectomía [a una mujer]. Normalmente en part. \\
\hline mastológico - ca adj & (Med) De (la) mastología o de su objeto. \\
\hline mastólogo - ga $m$ y $f$ & (Med) Especialista en mastología. \\
\hline maternológico - ca adj & $\{$ Med $)$ De (la) maternología o de su objeto. \\
\hline monoterapia $f$ & (Med) Terapia con un solo tratamiento o medicamento. \\
\hline necrosante $a d j$ & (Med y Biol) Que produce necrosis. Tb (lit) fig. \\
\hline necrotizante $a d j$ & (Med) Necrosante. \\
\hline necrotizar $t r$ & (Med) Necrosar. $T b p r$. \\
\hline neonatólogo -ga $m$ y $f$ & (Med) Especialista en neonatología. \\
\hline neuroanatomista $m$ y $f$ & (Med) Especialista en neuroanatomía. \\
\hline $\begin{array}{l}\text { neuroendocrinológico }-\mathrm{ca} \\
\text { adj }\end{array}$ & (Med) De (la) neuroendocrinología o de su objeto. \\
\hline $\begin{array}{l}\text { neuroendocrinólogo }-\mathrm{ga} m \\
\mathrm{y} f\end{array}$ & Med) Especialista en neuroendocrinología. \\
\hline neurohistología $f$ & (Med) Histología del sistema nervioso. \\
\hline neurohistológico - ca adj & (Med) De (la) neurohistología o de su objeto. \\
\hline neurohistólogo -ga $m$ y $f$ & (Med) Especialista en neurohistología. \\
\hline neuroma $m$ & (Med) Tumor benigno formado por tejido nervioso. \\
\hline neuropatológico - ca adj & (Med) De (la) neuropatología o de su objeto. \\
\hline neuropatólogo -ga $m$ y $f$ & $(M e d)$ Especialista en neuropatología. \\
\hline neuropediatra $m$ y $f$ & (Med) Especialista en neuropediatría. \\
\hline neuropediatría $f$ & (Med) Rama de la medicina que estudia las enfermedades nerviosas de los niños. \\
\hline neuropediátrico -ca adj & (Med) De (la) neuropediatría o de su objeto. \\
\hline neuropsicología $f$ & (Med) Rama de la medicina que trata de los casos a la vez neurológicos y psicológicos. \\
\hline neuropsicológico -ca adj & (Med) De (la) neuropsicología o de su objeto. \\
\hline neuropsicólogo - ga $m$ y $f$ & (Med) Especialista en neuropicología. \\
\hline neurorradiológico - ca $a d j$ & (Med) De (la) neurorradiología o de su objeto. \\
\hline
\end{tabular}




\begin{tabular}{|c|c|}
\hline neurorradiológo -ga $m$ y $f$ & (Med) Especialista en neurorradiologia. \\
\hline nutrológico -ca adj & (Med) De (la) nutrología o de su objeto. \\
\hline odontopedriatía $f$ & (Med) Odontología infantil. \\
\hline onco-pref & (Med) De (los) tumores y esp. De(l) cáncer. \\
\hline oncochip (pl normal, $\sim \mathrm{s}) \mathrm{m}$ & $(\mathrm{Med})$ Dispositivo de análisis genético que permite predecir y diagnosticar el cáncer. \\
\hline ortorexia $f$ & (Med) Obsesión patológica por la comida sana. \\
\hline ortoréxico -ca adj & (Med) De (la) ortorexia o que la implica. 2 (Med) Que padece ortorexia. Tb $n$. \\
\hline ortotanasia $f$ & $(M e d)$ Hecho de no alargar ni acortar la vida artificialmente a un enfermo incurable. \\
\hline osteopenia $f$ & (Med) Pérdida de masa ósea. \\
\hline otoplastia $f$ & (Med) Cirugía plástica de las orejas. \\
\hline paidológico - ca adj & (Med) De (la) paidología o de su objeto. \\
\hline paidólogo -ga $m$ y $f$ & (Med) Especialista en paidología. \\
\hline papilomavirus ( $p l$ invar) $m$ & (Med) Virus del papiloma (gén. Papillomavirus). \\
\hline perinatológico - ca adj & (Med) De (la) perinatología o de su objeto. \\
\hline periodontista $m$ y $f$ & (Med) Especialista en periodoncia. \\
\hline pet (acrónimo ing) $m$ o $f$ & (Med) Tomografía por emisión de positrones, usada especialmente para escáner cerebral \\
\hline planigrama $m$ & (Med) Tomograma. \\
\hline pletismografía $f$ & (Med) Medida de las variaciones de volumen de un miembro mediante el pletismógrafo. \\
\hline podal adj & (Med) De(l) pie. \\
\hline poliposis $f$ & (Med) Desarrollo de pólipos [2] múltiples. \\
\hline polisomnografía $f$ & (Med) Registro gráfico de una serie de constantes fisiológicas durante el sueño. \\
\hline polisomnográfico -ca adj & (Med) De (la) polisomnografía. \\
\hline posparto $(t b$ postparto) $m$ & $\begin{array}{l}\text { I adj invar } 1 \text { (Med) Posterior al parto. } \\
\text { II } \mathrm{m} 2 \text { (Med) Puerperio. }\end{array}$ \\
\hline posquirúrgico -ca adj & (Med) Inmediatamente posterior a una operación quirúrgica. \\
\hline postraumático -ca adj & (Med) Que se produce tras un trauma, esp. como consecuencia de él. \\
\hline potomanía $f$ & $\begin{array}{l}\text { (Med) Impulso morboso e irresistible a beber a menudo grandes cantidades de agua u otro } \\
\text { líquido. }\end{array}$ \\
\hline potomaníaco -ca adj & (Med) Que padece potomanía. $T b n$. \\
\hline primario -ria adj & c) $(\mathrm{Med})$ Que aparece en primer lugar o no deriva de otro. \\
\hline pronador -ra $a d j$ & $2(\mathrm{Med})$ [Pers.] que apoya en exceso la parte interior del pie al correr \\
\hline prosopagnosia $f$ & (Med) Incapacidad de reconocer los fisonomías. \\
\hline psicopatólogo -ga $m$ y $f$ & (Med) Especialista en psicopatología. \\
\hline pubalgia $f$ & (Med) Dolor del pubis. \\
\hline puente $m$ & $\begin{array}{l}11 \text { (Med) Operación quirúrgica que consiste en salvar un segmento vascular obstruido, } \\
\text { mediante un injerto de arteria, vena o tubo de plástico. Tb el mismo injerto. }\end{array}$ \\
\hline puerilismo $m$ & (Med) Infantilismo. \\
\hline pulsímetro $m$ & (Med) Pulsómetro. \\
\hline querato- pref & (Med) De (la) córnea o de(l) tejido córneo. \\
\hline queratomía $f$ & (Med) Queratoplastia. \\
\hline queratosis $f$ & (Med) Crecimiento o engrosamiento corneo, esp. en la piel. \\
\hline quinesiológico -ca adj & (Med) De (la) quinesiología o de su objeto. \\
\hline quinesiólogo - ga $m$ y $f$ & (Med) Especialista en quinesiología. \\
\hline
\end{tabular}




\begin{tabular}{|c|c|}
\hline raspaje $m$ & (Med) Raspado. Gralm en odontología. \\
\hline reflexoterapeuta $m$ y $f$ & (Med) Especialista en reflexoterapia. \\
\hline refractivo - va $a d j$ & (Fís o Med) De (la) refracción, esp. ocular. b) (Med) Que corrige la refracción ocular. \\
\hline retinosquisis $f$ & (Med) Separación patológica de las capas de la retina \\
\hline retroviral $a d j$ & (Med) De (los) retrovirus. 2 (Med) Antirretroviral. $T b n \mathrm{~m}$ \\
\hline revascularización $f$ & (Med) Operación quirúrgica para restablecer el flujo normal de sangre en una zona. \\
\hline rinólogo - ga $m$ y $f$ & (Med) Especialista en rinología. \\
\hline rinoscopia $f$ & (Med Exploración de las cavidades nasales. \\
\hline risoterapia $f$ & (Med) Tratamiento terapéutico mediante la risa. \\
\hline saburra $f$ & $\begin{array}{l}\text { (Med) Secreción mucosa espesa, presente en las paredes del estomago o formando una capa } \\
\text { blancuzca o amarillenta sobre la lengua, gralm. por trastornos digestivos. }\end{array}$ \\
\hline senológico - ca adj & (Med) De (la) senología o de su objeto. \\
\hline senólogo -ga $m$ y $f$ & (Med) Especialista en senología \\
\hline sexomnia $f$ & Sexomnio. \\
\hline sexomne adj & \{Med) Que padece sexomnio. Frec n. \\
\hline sexomnio $m$ & (Med) Trastorno que provoca actividad sexual mientras se duerme. \\
\hline sociopatía $f$ & $\begin{array}{l}\text { (Med) Trastorno de la personalidad caracterizado por actitudes y comportamiento } \\
\text { antisociales. }\end{array}$ \\
\hline stent ( $p l$ normal, -s) $m$ & (Med) Pr-otesis que se coloca en el interior de un vaso estenosado para mantenerlo abierto. \\
\hline sugestivo-va $a d j$ & 3 (Med) Que sugiere [algo (compl DE)]. \\
\hline supinador -ra adj & $2(\mathrm{Med})$ [Pers.] que apoya en exceso la parte exterior del pie al correr. \\
\hline taquilalia $f$ & $\begin{array}{l}\text { (Med o lit) Alteración del lenguaje caracterizada por una excesiva aceleración en la emisión } \\
\text { de las palabras. }\end{array}$ \\
\hline terapista $m$ y $f$ & (Med) Auxiliar sanitario especializado en terapia. \\
\hline tetralogía $f \sim$ de $f$ allot & (Med) Conjunto de cuatro defectos cardíacos congénitos. \\
\hline tiflólogo -ga $m$ y $f$ & (Med) Especialista en tiflología. \\
\hline tiflotecnia $f$ & (Med) Tiflotecnología. \\
\hline tiflotécnico -ca adj & (Med) Tiflotecnológico. \\
\hline tiflotecnología $f$ & (Med) Tecnología para los ciegos. \\
\hline tiflotecnológico -ca adj & (Med) De (la) tiflotecnología. \\
\hline tisiológico -ca adj & (Med) De (la) tisiología o de su objeto. \\
\hline tolerante $a d j$ & 3 (Med) Que tolera [2]. \\
\hline transvaginal adj & (Med) Que se produce a través de la vagina. \\
\hline tricofagia $f$ & (Med) Hábito de comerse el propio pelo. \\
\hline triquinósico - ca adj & $(\mathrm{Med})$ Triquinoso \\
\hline trocar (frec trócar) $m$ & $\begin{array}{l}\text { (Med) Instrumento quirúrgico consistente en un punzón envuelto en una vaina o cánula, } \\
\text { usado frec. para la evacuación de líquidos. }\end{array}$ \\
\hline trombectomía $f$ & (Med) Extracción o escisión de un trombo. \\
\hline tromboangitis $f$ & $\begin{array}{l}\text { (Med) Inflamación de la membrana interior de un vaso sanguíneo, con producción de } \\
\text { trombo. }\end{array}$ \\
\hline tromboembolia $f$ & (Med) Embolia u obstrucción causada en un vaso sanguíneo por un trombo. \\
\hline tromboembolismo $m$ & (Med) Tromboembolia. \\
\hline trombólisis ( $t b$ trombolisis) $f$ & Med) Destrucción de trombos. \\
\hline
\end{tabular}




\begin{tabular}{|c|c|}
\hline tularemia $f$ & $\begin{array}{l}\text { (Med) Enfermedad infecciosa que afecta esp. a roedores salvajes y que puede trasmitirse a } \\
\text { los seres humanos. }\end{array}$ \\
\hline ulcerante $a d j$ & (Med o lit) Que causa úlcera o que la implica. \\
\hline urgentólogo -ga $m$ y $f$ & (Med) Médico dedicado a urgencias [2c]. \\
\hline vaginismo $m$ & $\begin{array}{l}\text { (Med) Contracción espasmódica dolorosa del músculo constrictor de la vagina, que impide } \\
\text { o dificulta el coito. }\end{array}$ \\
\hline valvuloplastia $f$ & (Med) Cirugía reparadora de una válvula cardíaca. \\
\hline varicocele $m$ & (Med) Tumor formado por dilatación de una vena del escroto o del cordón espermático. \\
\hline variolación $f$ & (Med) Variolización. \\
\hline variolizar tr & $\begin{array}{l}\text { (Med) Inocular [a alguien }(c d) \text { ] el virus de la viruela benigna no modificado, como medida } \\
\text { profiláctica. }\end{array}$ \\
\hline venereólogo -ga $m$ y $f$ & (Med) Especialista en venereología. \\
\hline venografía $f$ & Med) Flebografía. \\
\hline venopunción $f$ & (Med) Punción en una vena para extraer sangre o inyectar una sustancia. \\
\hline ventilador $m$ & 4 (Med) Respirador (aparato). \\
\hline vigorexia $f$ & Med) Obsesión patológica por estar musculado. \\
\hline vigoréxico -ca adj & (Med) De (la) vigorexia o que la implica. 2 (Med) Que padece vigorexia. Tb $n$. \\
\hline vih (sigla) $m$ & (Med) Virus causante del sida. \\
\hline volemia $f$ & (Med) Volumen de la sangre. \\
\hline xenoinjerto $m$ & (Med) Heteroinjerto. \\
\hline $\begin{array}{l}\text { xenotrasplante }(t b, \quad \text { raro, } \\
\text { xenotransplante }) m\end{array}$ & (Med) Heterotrasplante. \\
\hline xerostomía $f$ & (Med) Sequedad de boca. \\
\hline
\end{tabular}

\section{ANEXO II}

Pronador/supinador; valgo/varo en dtm y dea

\begin{tabular}{|c|c|c|c|}
\hline DTM & & DEA & \\
\hline $\begin{array}{l}\text { pie valgo [ingl. } \\
\text { talipes valgus, } \\
\text { clubfoot] }\end{array}$ & $\begin{array}{l}1 \text { Deformidad permanente en } \\
\text { la que la planta del pie rota } \\
\text { hacia fuera, en pronación o } \\
\text { eversión, de modo que su } \\
\text { apoyo se realiza sobre el borde } \\
\text { interno, y además adopta una } \\
\text { actitud de abducción, con la } \\
\text { punta dirigida hacia fuera. } \\
\text { Habitualmente se asocia al } \\
\text { pie plano. } \\
\text { Sin.: pie abducto, pie pronado; } \\
\text { desus.: estrefexopodia. }\end{array}$ & pie I & $\begin{array}{l}\text { b) } \sim \text { equino, } \sim \text { plano, } \sim \text { valgo, etc } \rightarrow \text { equino, plano, } \\
\text { valgo, etc. }\end{array}$ \\
\hline
\end{tabular}




\begin{tabular}{|c|c|c|}
\hline $\begin{array}{l}\text { valgo, -ga [ingl. } \\
\text { valgus] }\end{array}$ & $\begin{array}{l}1 \text { adj. Aplicado a una valgo -ga } \\
\text { articulación o a un hueso } \\
\text { de las extremidades, sobre } \\
\text { todo inferiores: desviado o } \\
\text { inclinado hacia fuera, lejos } \\
\text { de la línea media del cuerpo o } \\
\text { del eje de la extremidad. } \\
\text { Obs.: Generalmente por } \\
\text { contraposición a } \rightarrow \text { varo, -ra. }\end{array}$ & $\begin{array}{l}\text { adj (Med) Desviado hacia fuera. Tb en } \sim \| \text { SYa } \\
\text { 7.10.84, 35: Se conforma así una estructura admirable, } \\
\text { que mecánicamente puede alterarse en el pie plano, o } \\
\text { equino, o talo, o bien apoyando hacia adentro o varo, } \\
\text { o por fuera o valgo .. Las rodillas pueden estar lejanas } \\
\text { en las rodillas en varo o paréntesis, y demasiado } \\
\text { próximas o en valgo. }\end{array}$ \\
\hline $\begin{array}{l}\text { pie varo [ingl. } \\
\text { talipes varus] }\end{array}$ & $\begin{array}{l}1 \text { Deformidad permanente en } \\
\text { la que la planta del pie rota } \\
\text { hacia dentro, en supinación } \\
\text { o inversión, de modo que su } \\
\text { apoyo en el suelo se realiza } \\
\text { sobre el borde externo, y } \\
\text { además adopta una posición } \\
\text { en aducción, con la punta } \\
\text { dirigida hacia dentro. } \\
\text { Habitualmente se asocia al } \\
\text { pie equino y al pie cavo. } \\
\text { Sin.: pie aducto, pie supinado; } \\
\text { desus.: estrefenopodia. }\end{array}$ & No figura. \\
\hline $\begin{array}{l}\text { varo, -ra } \quad \text { ingl. } \\
\text { varus }]\end{array}$ & $\begin{array}{l}1 \text { adj. Aplicado a una varo } \\
\text { articulación o a un hueso } \\
\text { de las extremidades, sobre } \\
\text { todo inferiores: desviado o } \\
\text { inclinado hacia dentro, hacia } \\
\text { la línea media del cuerpo o del } \\
\text { eje de la extremidad. } \\
\text { Obs.: Generalmente por } \\
\text { contraposición a } \rightarrow \text { valgo, -ga. }\end{array}$ & $\begin{array}{l}\text { adj (Med) Desviado hacia dentro. Tb en } \sim \text {. } \| \text { SYa } \\
\text { 7.10.84, 35: Se conforma así una estructura admirable, } \\
\text { que mecánicamente puede alterarse en el pie plano, o } \\
\text { equino, o talo, o bien apoyando hacia adentro o varo, } \\
\text { o por fuera o valgo .. Las rodillas pueden estar lejanas } \\
\text { en las rodillas en varo o paréntesis y demasiado } \\
\text { próximas o en valgo. }\end{array}$ \\
\hline pronador, -ra & $\begin{array}{l}1 \text { [ingl. pronator] adj. Que pronador -ra } \\
\text { produce pronación. } \\
2 \text { s.m. = músculo pronador. }\end{array}$ & $\begin{array}{l}\text { adj } 1 \text { (Anat) De (la) pronación. Tb n m, referido } \\
\text { a músculo. II Artero Hombre 82: Músculos de las } \\
\text { extremidades .. Pronador, para poner la palma de } \\
\text { la mano hacia abajo; supinador, para ponerla hacia } \\
\text { arriba. } \\
2 \text { (Med) [Pers.] que apoya en exceso la parte interior } \\
\text { del pie al correr. \| SEIM 15.1. 00In: Averiguar } \\
\text { si es pronador (desvía el pie hacia el interior en } \\
\text { la pisada), supinador (lo contrario) o neutro, con } \\
\text { el fin de establecer si necesita o no una plantilla } \\
\text { correctora, b) Propio de la pers. pronadora. \| As } \\
\text { 24.4.051": La mayoría de los deportistas que vienen } \\
\text { a la consulta tienen un pie pronador. EIM 8.5.07In: } \\
\text { Pisada pronadora. }\end{array}$ \\
\hline
\end{tabular}




\begin{tabular}{ll}
\hline supinador, -ra & 1 [ingl. supinator] adj. Que supinador -ra \\
& produce supinación. \\
& 2 s.m. $=$ músculo supinador.
\end{tabular}

adj 1 (Anat) De (la) supinación. Tb $\mathrm{n}$

m, referido a músculo. \| Artero Hombre 82: Músculos de las extremidades .. Pronador, para poner la palma de la mano hacia abajo; supinador, para ponerla hacia arriba.

2 (Med) [Pers.] que apoya en exceso la parte exterior del pie al correr. $\|$ SEIM 15.1.00In: Averiguar si es pronador (desvía el pie hacia el interior en la pisada), supinador (lo contrario) o neutro, con el fin de establecer si necesita o no una plantilla correctora, b) Propio de la pers. supinadora. || SEIM 16.5.051": Los entrenamientos mal dirigidos .., tener un pie cavo, una pisada supinadora, etc. pudieron ser los causantes de este dolor en la rodilla.

\section{ANEXO III}

Nuevas acepciones

\begin{tabular}{|c|c|c|}
\hline VOCABLO & 1. ${ }^{\mathrm{a}}$ EDICIÓN & 2. ${ }^{\mathrm{a}}$ EDICIÓN \\
\hline adrenérgico -ca adj & $(\mathrm{Med}) 1$ Activado por la adrenalina. & $\begin{array}{l}(\mathrm{Med}) \text { Activado por la adrenalina. 2. }(\mathrm{Med}) \\
\text { Producido por la adrenalina }\end{array}$ \\
\hline alálico -ca adj & (Med o lit.) Álalo. $T b n$. & $\begin{array}{l}1 \text { (Med o lit.) De la alalia o que la implica. } 2 \\
(\text { Med o lit.) Álalo. } T b n .\end{array}$ \\
\hline anoréxico -ca $a d j$ & (Med) Que padece anorexia. $\mathrm{Tb} \mathrm{n}$. & $\begin{array}{l}1(M e d) \text { De (la) anorexia o que la implica. } 2 \\
(M e d) \text { Que padece anorexia. } T b n .\end{array}$ \\
\hline atáxico -ca $a d j$ & $(\mathrm{Med}) \mathrm{De}(\mathrm{la})$ ataxia. & $\begin{array}{l}1(\mathrm{Med}) \mathrm{De}(\mathrm{la}) \text { ataxia. } 2(\mathrm{Med}) \text { Que padece } \\
\text { ataxia. } \mathrm{Tb} n \text {, referido a pers. }\end{array}$ \\
\hline autólisis $f$ & $\begin{array}{l}\text { (Biol) Desintegración espontánea de las células o } \\
\text { de los tejidos por fermentos segregados por ellos } \\
\text { mismos. }\end{array}$ & $\begin{array}{l}\text { (Biol) Desintegración espontánea de las } \\
\text { células o de los tejidos por fermentos } \\
\text { segregados por ellos mismos. } 2 \text { (Med o lit) } \\
\text { Suicidio. }\end{array}$ \\
\hline bala mágica $f$ & No figura esta subentrada. & $\begin{array}{l}5 \sim \text { mágica (argot Med) Remedio maravilloso } \\
\text { o muy eficaz. }\end{array}$ \\
\hline balón $m$ & No se incluye ningún sentido médico. & $\begin{array}{l}3 \text { (Med) Bola hinchable que se une } \\
\text { normalmente a un catéter. Frec } \sim \text { hinchable. }\end{array}$ \\
\hline bipolar adj & (E) Que tiene dos polos. Tb fig, esp en política. & $\begin{array}{l}\text { (E) Que tiene dos polos. Tb fig, esp en politica. } \\
2 \text { (Med) [Trastorno] maniacodepresivo. b) } \\
\text { [Pers.] que padece trastorno bipolar. } T b n\end{array}$ \\
\hline cacosmia $f$ & $\begin{array}{l}\text { (Med) Percepción morbosa de malos olores que no } \\
\text { existen. }\end{array}$ & $\begin{array}{l}\text { (Med) Percepción morbosa de malos olores } \\
\text { que no existen. } 2 \text { (Med) Halitosis. }\end{array}$ \\
\hline caliente $^{1}$ adj & No se incluye ningún sentido médico. & $\begin{array}{l}13 \text { (Med) [Nodulo] que capta el yodo } \\
\text { radiactivo en la gammagrafía. }\end{array}$ \\
\hline carcinógeno -na adj & (Med) Que produce cáncer. $T b n$ m, referido a agente. & $\begin{array}{l}(\mathrm{Med}) \text { Que produce cáncer. } \mathrm{Tb} n \mathrm{~m} \text {, referido } \\
\text { a agente. } 2(\mathrm{Med}) \text { Carcinogénico }\end{array}$ \\
\hline casuístico-ca ii $f$ & No se incluye ningún sentido médico. & $\begin{array}{l}2 \text { c) (Med) Estudio y registro de casos } \\
\text { particulares de una enfermedad. }\end{array}$ \\
\hline compasivo - va adj & No se incluye ningún sentido médico. & $\begin{array}{l}3 \text { (Med) [Uso] de un medicamento antes } \\
\text { de ser aprobado oficialmente, por razones } \\
\text { humanitarias. }\end{array}$ \\
\hline
\end{tabular}




\begin{tabular}{|c|c|}
\hline conjugado - da adj & No se incluye ningún sentido médico. \\
\hline corroborante adj & No se incluye ningún sentido médico. \\
\hline crisis $f$ & $\begin{array}{l}2 \text { b) (Med) Cambio rápido e importante en la } \\
\text { evolución de la fiebre o de una enfermedad, en sentido } \\
\text { favorable o adverso. Frec en la constr HACER . Tb } \\
\text { fig, fuera del ámbito técn. Se opone a LISIS. }\end{array}$ \\
\hline
\end{tabular}

6 (Med) [Vacuna] de varios componentes combinados.

2 (Med) Tónico. Tb $n$ m.

2 b) (Med) Cambio rápido e importante en la evolución de la fiebre o de una enfermedad, en sentido favorable o adverso. Frec en la constr HACER . Tb fig, fuera del ámbito técn. Se opone a LISIS. c) (Med) Ataque en un órgano o parte, o intensificación brusca de los síntomas de una enfermedad.

\begin{tabular}{|c|c|}
\hline dislálico -ca adj & $(\mathrm{Med})$ Que padece dislalia. $T b n$ \\
\hline displásico -ca adj & (Med) De (la) displasia. \\
\hline $\begin{array}{l}\text { eccematoso -sa ( } t b \text { con } \\
\text { la grafia eczematoso) } \\
\text { adj }\end{array}$ & De(1) eccema. \\
\hline elongación $f$ & $\begin{array}{l}3 \text { (Fis) Alargamiento de una pieza sometida a } \\
\text { tracción. }\end{array}$ \\
\hline escíbalo $m$ & Cagarruta \\
\hline escrófula $f$ & $\begin{array}{l}\text { (Med) Estado de debilidad general con predisposición } \\
\text { a enfermedades infecciosas, especialmente } \\
\text { tuberculosis, que se manifiesta por inflamación de los } \\
\text { ganglios linfáticos }\end{array}$ \\
\hline
\end{tabular}

(Med) De (la) dislalia o que la implica. 2. (Med) Que padece dislalia. $T b n$.

(Med) De (la) displasia. 2 (Med) Que padece displasia. $T b n$.

(Med) De(l) eccema o que lo implica. 2 (Med) Que padece eccema. $T b n$, referido a pers

(Med o lit) Acción de elongar(se). b ) (Med) Lesión producida por una elongación accidental. c) (Fis) Alarga-miento de una pieza sometida a tracción.

(Med) Porción de excre-mento duro en el intestino. b) (raro) Cagarruta

(Med) Estado de debilidad general con predisposición a enfermedades infecciosas, especialmente tuberculosis, que se manifiesta por inflamación de los ganglios linfáticos. 2 (Med) Absceso o fístula propios de la escrófula [1]. Tb la úlcera que produce.

\begin{tabular}{|c|c|c|}
\hline escrofuloso -sa adj $\neg$ & Que padece escrofula. $\mathrm{Tb} \mathrm{n}$. $\mathrm{Tb}$ (lit) fig. & $\begin{array}{l}\text { (Med) De (la) escrófula. } 2 \text { (Med) Que padece } \\
\text { escrófula. } T b \text { n, referido a pers. Tb (lit) fig. }\end{array}$ \\
\hline gafa $f$ & No se incluye ningún sentido médico. & $\begin{array}{l}2 \text { (Med) En pl: Utensilio compuesto por un } \\
\text { tubito de plástico con dos prolongaciones } \\
\text { que se introducen en los agujeros de la } \\
\text { nariz y que sirve para inhalar oxígeno. } T b \\
\sim \text { de oxígeno. }\end{array}$ \\
\hline
\end{tabular}

\begin{tabular}{|c|c|c|}
\hline garra, en loc adj & No se incluye ningún sentido médico. & $\begin{array}{l}\text { II } 9 \text { (Med) [Dedo] deformado con las últimas } \\
\text { falanges encogidas. }\end{array}$ \\
\hline gaseoso -sa adj & $\begin{array}{l}2 \text { b) }(\mathrm{Med}) \text { [Gangrena) difusa del tejido celular } \\
\text { subcutáneo, con producción de gases, y que es debida } \\
\text { a varios microbios. }\end{array}$ & $\begin{array}{l}2 \text { b) (Med) [Gangrena) difusa del tejido } \\
\text { celular subcutáneo, con producción de gases, } \\
\text { y que es debida a varios microbios. } 2 \text { c) } \\
\text { (Med) Que se realiza con gas. }\end{array}$ \\
\hline glaucomatoso -sa adj & (Med) De(l) glaucoma. & $\begin{array}{l}\text { (Med) De(l) glaucoma. } 2 \text { (Med) Que padece } \\
\text { glaucoma. } T b \text {, referido a pers. }\end{array}$ \\
\hline gotoso -sa $a d j \neg$ & Que padece gota. $T b n$, referido a pers. & $\begin{array}{l}\text { (Med) De la gota }{ }^{2} \text { o que la implica. } 2 \text { (Med) } \\
\text { Que padece } \operatorname{gota}^{2} . T b \text {, referido a pers. }\end{array}$ \\
\hline granulomatoso -sa adj & $\begin{array}{l}(\mathrm{Med}) \text { De(l) granuloma o que tiene caracteres de } \\
\text { granuloma. }\end{array}$ & $\begin{array}{l}\text { (Med) De(l) granuloma o que lo implica. } 2 \\
(M e d) \text { Que presenta o padece un granuloma. } \\
T b \text {, referido a pers. }\end{array}$ \\
\hline
\end{tabular}

hábito $m$ Tendencia individual a obrar de un modo 5 (Med) Temperamento o disposición. determinado, adquirida por la reiteración de un acto. b) Necesidad morbosa. 


linfático -ca adj $\neg \quad 1$ (E) De (la) linfa, esp [1]. Tb n m, referido a vaso.

$1(E)$ De (la) linfa, esp [1]. Tb $n$ m, referido a vaso.
(E) De (la) linfa, esp [1], o que la contiene. Tb $n$ m, referido a vaso. 2 (Med) [Pers.] caracterizada por predominio del sistema linfático [1], poca presión y tendencia a la obesidad fofa. $\mathrm{Tb}$ n. c) (Med o lit) Propio de la pers. linfática.

linfocitario -ria adj (Anat) De(l) linfocito o de (los) linfocitos.

lumen (pl invar o No se incluye ningún sentido médico. es) $m$

\begin{tabular}{ll}
\hline luminar adj & No se incluye ningún sentido médico. \\
\hline mal $m$ & 3 Enfermedad. Frec con un comp especificador. b) \\
& gran $\sim$ Epilepsia cnvulsiva. e) $\sim$ de la rosa. Pelagra. \\
& g) $\sim$ de orina. Enfermedad del aparato urinario, que \\
& ocasiona dificultad o incontinencia en la excreción \\
& de la orina. h) $\sim$ de piedra. Enfermedad caracterizada \\
& por la presencia de cálculos en las vías urinarias. i) \\
& $\sim$ de Pott $($ Med $)$ Afección inflamatoria tuberculosa \\
& de la columna vertebral. j) $\sim$ de San Lázaro. Lepra. \\
& k) $\sim$ francés. Sifilis. 1$) \sim$ sagrado (lit) Epilepsia. m) \\
pequeño $\sim$. Epilepsia no convulsiva
\end{tabular}

\begin{tabular}{|c|c|c|}
\hline masivo -va adj & $1 \mathrm{~b})(\mathrm{Med})$ Abundante o copioso. & $\begin{array}{l}1 \mathrm{~b})(\mathrm{Med}) \text { Abundante o copioso. c) (Med) } \\
\text { Que afecta a un área extensa. }\end{array}$ \\
\hline naturópata $a d j$ & $(\mathrm{Med})$ Especialista en naturopatía. & $\begin{array}{l}\text { (Med) Especialista en naturopatía. Frec } n .2 \\
(M e d) \text { De (la) naturopatía. }\end{array}$ \\
\hline nodo $^{1} m$ & No se incluye ningún sentido médico. & 4 (Anat y Med) Nodulo [1]. \\
\hline pandémico -ca adj & $(\mathrm{Med})$ (Enfermedad) que tiene carácter de pandemia. & $\begin{array}{l}\text { (Med) [Enfermedad] que tiene carácter de } \\
\text { pandemia. } 2(\mathrm{Med}) \text { [Agente] que causa una } \\
\text { pandemia. }\end{array}$ \\
\hline paranoico -ca adj & (Med) De (la) paranoia. & $\begin{array}{l}\text { (Med) De (la) paranoia. } 2 \text { (Med) Que padece } \\
\text { paranoia. } T b n .\end{array}$ \\
\hline patología $f \neg$ & $\begin{array}{l}\text { Estudio de las enfermedades y de los trastornos que } \\
\text { causan en el organismo. b) Conjunto de enfermedades } \\
\text { o trastornos [de alguien o algo]. }\end{array}$ & $\begin{array}{l}(\mathrm{Med}) \text { Estudio de las enfermedades y de los } \\
\text { trastornos que causan en el organismo. b) } \\
\text { Conjunto de enfermedades o trastornos [de } \\
\text { alguien o algo]. c) Enfermedad. }\end{array}$ \\
\hline pelagroso -sa $a d j$ & [Pers] que padece pelagra. $T b n$. & $\begin{array}{l}\text { (Med) De (la) pelagra o que la implica. } 2 \\
\text { (Med) Que padece pelagra. } T b \text {, referido } \\
\text { a pers. }\end{array}$ \\
\hline poligrafía $f$ & No se incluye ningún sentido médico. & $\begin{array}{l}3 \text { (Med) Técnica de examen o prueba } \\
\text { mediante el polígrafo [2]. }\end{array}$ \\
\hline polínico -ca adj & Del polen. & $\begin{array}{l}\text { Del polen. } 2 \text { (Med) [Pers] alérgica al polen. } \\
T b n .\end{array}$ \\
\hline $\begin{array}{l}\text { post partum (lat; } \\
\text { pronunc corriente, / } \\
\text { pos-pártum/) loc adj } \neg\end{array}$ & Posterior al parto. $T b n \mathrm{~m}$, referido a periodo. & $\begin{array}{l}\text { I loc adv } 1(\mathrm{Med}) \text { Después del parto. } T b \\
n \mathrm{~m} \text { referido a periodo. II loc adj } 2 \text { (Med) } \\
\text { Posparto } T b n . m \text {. }\end{array}$ \\
\hline primario -ria adj $\neg$ & No se incluye ningún sentido médico. & $\begin{array}{l}3 \text { c) (Med) Que aparece en primer lugar o no } \\
\text { deriva de otro. }\end{array}$ \\
\hline pronador-ra adj & No se incluye. & $\begin{array}{l}2(\mathrm{Med}) \text { [Pers.] que apoya en exceso la parte } \\
\text { interior del pie al correr. }\end{array}$ \\
\hline
\end{tabular}

(Anat) De(1) linfocito o de (los) linfocitos. b ) (Med) Caracterizado por la presencia de linfocitos.

2 (Med) Luz (área interior de la sección

I I adj 2 (Fis o Med) Del lumen.
morboso debido a la disminución de la presión atmosférica. f) $\sim$ de Chagas $\rightarrow$ Chagas. g) de Creutzfeldt-Jacob. (Med) Encefalopatía espongiforme. i) $\sim$ de las vacas locas $\rightarrow$ Loco. j) $\sim$ de mar. Mareo provocado por los movimientos de una embarcación. transversal de un conducto).

d) $\sim$ de altura o de la(s) montaña(s). Estado 


\begin{tabular}{|c|c|c|}
\hline puente $m$ & No se incluye ningún sentido médico. & $\begin{array}{l}11 \text { (Med) Operación quirúrgica que consiste } \\
\text { en salvar un segmento vascular obstruido, } \\
\text { mediante un injerto de arteria, vena o tubo } \\
\text { de plástico. Tb el mismo injerto. }\end{array}$ \\
\hline pustuloso -sa adj & $(\mathrm{Med})$ Caracterizado por la presencia de pústulas. & $\begin{array}{l}\text { (Med) De (las) pústulas o que las implica. } \\
2 \text { (Med) Que tiene pústulas. } T b n \text {, referido } \\
\text { a pers. }\end{array}$ \\
\hline reflexología $f$ & $(\mathrm{Med})$ Estudio de los actos reflejos [2]. & $\begin{array}{l}\text { (Med) Sistema de masaje aplicado } \\
\text { a determinados puntos de los pies y de } \\
\text { las manos, para quitar tensión o curar } \\
\text { enfermedades. } 2 \text { (Psicol) Estudio de los } \\
\text { actos reflejos [2] en la conducta. }\end{array}$ \\
\hline rodadero -ra adj & No se incluye ningún sentido médico. & $\begin{array}{l}2 \text { (Med) [Tumor o ganglio] que se mueve o } \\
\text { no está fijo. }\end{array}$ \\
\hline silicótico -ca adj & (Med) Que padece silicosis. & $\begin{array}{l}\text { (Med) De la silicosis o que la implica. } 2 \\
\text { (Med) Que padece silicosis. } T b \text {, referido } \\
\text { a pers. }\end{array}$ \\
\hline sugestivo -va adj & No se incluye ningún sentido médico. & 3 (Med) Que sugiere [algo (compl DE)]. \\
\hline supinador -ra adj & No se incluye. & $\begin{array}{l}2(\mathrm{Med}) \text { [Pers.] que apoya en exceso la parte } \\
\text { exterior del pie al correr. }\end{array}$ \\
\hline tofoso - sa adj & (Med) Que tiene o implica tofos. & $\begin{array}{l}\text { (Med) De (los) tofos o que los implica. } 2 \\
(\mathrm{Med}) \text { Que tiene tofos. }\end{array}$ \\
\hline tolerante $a d j$ & No se incluye ningún sentido médico. & 3 (Med) Que tolera [2]. \\
\hline ventilador $m$ & No se incluye ningún sentido médico. & 4 (Med) Respirador (aparato). \\
\hline
\end{tabular}

\section{ANEXO IV}

Cambios en la definición

\begin{tabular}{|c|c|c|}
\hline VOCABLOS & DEFINICIÓN 1. ${ }^{\mathrm{a}}$ ed. & DEFINICIÓN 2. ed. \\
\hline adenomatoso -sa $a d j$ & $(\mathrm{Med})$ Que tiene los caracteres del adenoma & $\begin{array}{l}\text { (Med) Del(l) adenoma o que tiene los caracteres } \\
\text { de(l) adenoma. }\end{array}$ \\
\hline aerofagia $f$ & (Med) Deglución espasmódica de aire & (Med) Deglución de aire, que provoca eructos \\
\hline aerofobia $f$ & (Med) Temor morboso al aire & (Psicol) Temor morboso al aire o a la altura. \\
\hline afásico -ca adj & $\begin{array}{l}\text { (Med) Que padece afasia. } T b n .2(\mathrm{Med}) \mathrm{De} \\
\text { (la) afasia. }\end{array}$ & $\begin{array}{l}\text { (Med) Que padece afasia. } T b n .2 \text { (Med) De (la) } \\
\text { afasia o que la implica }\end{array}$ \\
\hline agorafobia $f$ & $\begin{array}{l}\text { (lit o Med) Temor u aversión a los espacios } \\
\text { abiertos. }\end{array}$ & $\begin{array}{l}\text { (lit o Psicol) Temor u aversión a los espacios } \\
\text { abiertos o públicos. }\end{array}$ \\
\hline alalia $f$ & $\begin{array}{l}\text { (Med) Pérdida de la facultad del lenguaje por } \\
\text { una afección de los órganos vocales o del } \\
\text { cerebro. Tb fuera del ámbito técn. }\end{array}$ & $\begin{array}{l}\text { (Med) Carencia total de la facultad del lenguaje } \\
\text { por una afección de los órganos vocales o del } \\
\text { cerebro. Tb (lit) fig, fuera del ambito tecn. }\end{array}$ \\
\hline álalo -la ( $t b$ alalo) $a d j$ & $\begin{array}{l}\text { (Med) Que padece alalia. } \mathrm{Tb} \text { fig, fuera del } \\
\text { ámbito técn. }\end{array}$ & (Med o lit) Que padece alalia. \\
\hline alergólogo -ga $m$ y $f$ & $\begin{array}{l}(\mathrm{Med}) \text { Especialista en enfermedades } \\
\text { alérgicas. }\end{array}$ & (Med) Especialista en alergología. \\
\hline $\begin{array}{l}\text { anafrodisíaco }-\mathrm{ca} \quad(t b \\
\text { anafrodisiaco }) a d j\end{array}$ & $\begin{array}{l}\text { (Med) Que disminuye o suprime el apetito } \\
\text { venéreo. } T b . n . m \text {., referido a sustancia. }\end{array}$ & $\begin{array}{l}\text { (Med) Que disminuye o suprime el apetito } \\
\text { sexual. Tb. n. m., referido a sustancia o agente }\end{array}$ \\
\hline
\end{tabular}




\begin{tabular}{|c|c|c|}
\hline analéptico -ca adj & $\begin{array}{l}(\mathrm{Med})[\text { Medicamento }) \text { que sirve para } \\
\text { restaurar o estimular las fuerzas. } T b n .\end{array}$ & $\begin{array}{l}\text { (Med) Que restaura o estimula las fuerzas. } T b \\
n m \text {, referido a medicamento. }\end{array}$ \\
\hline analgesia $f$ & (Med) Abolición de la sensibilidad al dolor. & $\begin{array}{l}\text { (Med) Supresión o disminución de la } \\
\text { sensibilidad al dolor. }\end{array}$ \\
\hline andrológico -ca adj & (Med) De (la) andrología. & (Med) De (la) andrología o de su objeto. \\
\hline anestesiológico $-\mathrm{ca} a d j$ & (Med) De la anestesiología. & (Med) De la anestesiología o de su objeto. \\
\hline angiográfico -ca adj & (Med) De (la) angiografía. & (Med) De la angiografía o de su objeto. \\
\hline angiológico -ca $a d j$ & (Med) De (la) angiología. & (Med) De la angiología o de su objeto. \\
\hline angioplastia $f$ & $\begin{array}{l}\text { (Med) Cirugía plástica de los vasos } \\
\text { sanguíneos. }\end{array}$ & $\begin{array}{l}\text { (Med) Cirugía reparadora de los vasos } \\
\text { sanguíneos, frec. mediante un catéter }\end{array}$ \\
\hline antibioterapia $f$ & (Med) Tratamiento con antibióticos. & (Med) Tratamiento terapéutico con antibióticos \\
\hline antibioticoterapia $f$ & Tratamiento con antibióticos. & (Med) Tratamiento terapéutico con antibióticos \\
\hline antidiurético -ca $a d j$ & (Med) Que impide la formación de orina. & $\begin{array}{l}\text { (Med) Que impide la diuresis o formación de } \\
\text { orina } T b \text { n. m. referido a medicamento o agente }\end{array}$ \\
\hline antifebril adj & $\begin{array}{l}\text { Que rebaja la fiebre. Tb. n. m., referido a } \\
\text { medicamento o remedio. }\end{array}$ & $\begin{array}{l}\text { (Med) Antipirético (que reduce o elimina la } \\
\text { fiebre). } T b n m\end{array}$ \\
\hline antirrábico-ca adj & $\begin{array}{l}\text { (Med) [Cosa, especialmente vacuna }] \\
\text { destinada a prevenir la rabia. }\end{array}$ & $\begin{array}{l}\text { (Med) }[\text { Cosa, especialmente vacuna] destinada } \\
\text { a prevenir la rabia. } T b n m \text {, referido a } \\
\text { medicamento o remedio. }\end{array}$ \\
\hline antitumoral $a d j$ & (Med) Eficaz contra los tumores. & $\begin{array}{l}\text { (Med) Eficaz contra los tumores. } T b n \mathrm{~m} \text {, } \\
\text { referido a medicamento o remedio. }\end{array}$ \\
\hline antitracomatoso -sa $a d j$ & (Med) Que combate el tracoma. & $\begin{array}{l}\text { (Med) Que previene o combate el tracoma o } \\
\text { está destinado a ello. }\end{array}$ \\
\hline antitusígeno - na $a d j$ & (Med) Que evita la aparición de la tos. & (Med) Antitusivo. \\
\hline antiviral adj & $(M e d)$ Antivírico. & $\begin{array}{l}\text { (Med) Que impide el desarrollo de los virus. } \\
T b n \text { m, referido a medicamento o agente. }\end{array}$ \\
\hline antivírico -ca adj. / n. m. & $\begin{array}{l}\text { (Med) Que impide el desarrollo de los virus. } \\
\text { También } n . \text { m., referido a medicamento o } \\
\text { agente. }\end{array}$ & (Med) Antiviral. \\
\hline apopléjico -ca adj & $\begin{array}{l}\text { No se incluye. En su lugar figura: } \\
\text { apoplético -ca adj De la apoplejía 2. Que } \\
\text { padece apoplejía. Tb n. } 3 \text { [Pers.] de rostro } \\
\text { congestionado, que denota predisposición } \\
\text { a la apoplejía. }\end{array}$ & (Med) Apoplético. \\
\hline arteriografía $f$ & (Med) Radiografía de las arterias. & $\begin{array}{l}\text { (Med) Procedimiento que permite la } \\
\text { visualización de las arterias, esp. por rayos } \\
\text { X o resonancia magnética. Frec la imagen asi } \\
\text { obtenida. }\end{array}$ \\
\hline artrítico-ca adj & $\begin{array}{l}(\mathrm{Med}) \mathrm{De}(\mathrm{la}) \text { artritis. } 2(\mathrm{Med}) \text { Que padece } \\
\text { artritis. } T b \text {, referido a pers. }\end{array}$ & $\begin{array}{l}\text { (Med) De (la) artritis o que la implica. } 2(\mathrm{Med}) \\
\text { Que padece artritis. } T b \text {, referido a pers. }\end{array}$ \\
\hline artrósico -ca adj & $\begin{array}{l}(\mathrm{Med}) \mathrm{De}(\mathrm{la}) \text { artrosis. } 2(\mathrm{Med}) \text { Que padece } \\
\text { artrosis. Tb n, referido a pers. }\end{array}$ & $\begin{array}{l}\text { (Med) De (la) artrosis o que la implica. } 2(\mathrm{Med}) \\
\text { Que padece artrosis. } T b \text {, referido a pers. }\end{array}$ \\
\hline atáxico -ca adj & $(\mathrm{Med}) \mathrm{De}(\mathrm{la})$ ataxia. & $\begin{array}{l}\text { (Med) De (la) ataxia. } 2 \text { (Med) Que padece } \\
\text { ataxia. } T b \text { n, referido a pers. }\end{array}$ \\
\hline aterosclerótico - ca adj & $(\mathrm{Med}) \mathrm{De}(\mathrm{la})$ aterosclerosis. & (Med) De (la) aterosclerosis o que la implica. \\
\hline atrésico - ca adj & $(M e d)$ Que tiene atresia. & $(\mathrm{Med})$ Que presenta atresia. \\
\hline audiológico - ca adj & (Med) De (la) audiología. & (Med) De (la) audiología o de su objeto. \\
\hline bacilar adj & $\begin{array}{l}\text { (Biol y Med) De(1) bacilo o de (los) bacilos. } \\
2 \text { Que se produce mediante bacilos. }\end{array}$ & $\begin{array}{l}\text { (Biol y Med) De(l) bacilo o de (los) bacilos. b) } \\
\text { Causado por bacilos. }\end{array}$ \\
\hline
\end{tabular}




\begin{tabular}{|c|c|c|}
\hline bioterapia $f$ & $\begin{array}{l}(\mathrm{Med}) \text { Método terapéutico mediante cultivos } \\
\text { vivos o productos orgánicos. }\end{array}$ & $\begin{array}{l}\text { (Med) Tratamiento terapéutico mediante } \\
\text { cultivos vivos o productos orgánicos. }\end{array}$ \\
\hline carbuncosis $f$ & $(\mathrm{Med})$ Infección carbuncosa. & (Med) Infección del carbunco. \\
\hline carcinogenético -ca adj & $(M e d)$ Que produce cáncer. & (Med) Carcinogénico. \\
\hline cinesiterapia $f$ & $\begin{array}{l}(\mathrm{Med}) \text { Método terapéutico por medio de } \\
\text { movimientos corporales activos o pasivos. }\end{array}$ & $\begin{array}{l}\text { (Med) Tratamiento terapeutico mediante } \\
\text { movimientos corporales activos o pasivos. }\end{array}$ \\
\hline crenoterapia $f$ & $(\mathrm{Med})$ Tratamiento por aguas minerales. & $\begin{array}{l}\text { (Med) Tratamiento terapéutico con aguas } \\
\text { minerales. }\end{array}$ \\
\hline crioterapia $f$ & $\begin{array}{l}\text { (Med) Método curativo basado en la } \\
\text { aplicación de temperaturas muy bajas. }\end{array}$ & $\begin{array}{l}\text { (Med) Tratamiento terapéutico basado en la } \\
\text { aplicación de temperaturas muy bajas. }\end{array}$ \\
\hline dermatológico -ca adj & De (la) dermatología. & (Med) De (la) dermatología o de su objeto. \\
\hline $\begin{array}{l}\text { dipsomaníaco } \quad-\text { ca } \quad(t b \\
\text { dipsomaniaco } a d j\end{array}$ & $(\mathrm{Med})$ Que padece dipsomanía. $T b n$. & (Med) Dipsómano. $T b n$. \\
\hline dipsómano -na adj & $(M e d)$ Dipsomaníaco. $T b n$. & (Med) Que padece dipsomanía. $T b n$. \\
\hline distress & $\begin{array}{l}(\mathrm{Med}) \text { Problema. Gralm en la constr } \sim \\
\text { respiratorio. }\end{array}$ & (Med.) Distrés. \\
\hline edematoso -sa adj & $\begin{array}{l}(\mathrm{Med}) \mathrm{De}(1) \text { edema. } 2 \text { Que padece edema. } \\
T b \text {, referido a pers. }\end{array}$ & $\begin{array}{l}\text { (Med) De(l) edema o que lo implica. } 2 \text { (Med) } \\
\text { Que padece edema. Tb n, referido a pers. }\end{array}$ \\
\hline $\begin{array}{l}\text { electroshockterapia } \\
\text { (pronunc corriente, / } \\
\text { elektrosokterápia/) }\end{array}$ & $(\mathrm{Med})$ Tratamiento por electroshock. & (Med) Tratamiento terapéutico por electroshock. \\
\hline electroterapia $f$ & $\begin{array}{l}(\mathrm{Med}) \text { Empleo de la electricidad en el } \\
\text { tratamiento de las enfermedades. }\end{array}$ & $\begin{array}{l}\text { (Med) Tratamiento terapéutico basado en el } \\
\text { empleo de la electricidad }\end{array}$ \\
\hline enterovirus $m$ & $\begin{array}{l}(\mathrm{Med}) \text { Virus que se puede aislar en el aparato } \\
\text { digestivo de los vertebrados y que suele } \\
\text { producir diversas infecciones. }\end{array}$ & $\begin{array}{l}\text { (Med) Virus del grupo que causa infecciones } \\
\text { en el aparato digestivo de los vertebrados. }\end{array}$ \\
\hline ergoterapia $f$ & $\begin{array}{l}(\mathrm{Med}) \text { Método terapéutico basado en el } \\
\text { trabajo físico. }\end{array}$ & $\begin{array}{l}(\mathrm{Med}) \text { Tratamiento terapéutico basado en el } \\
\text { trabajo físico. }\end{array}$ \\
\hline eritematoso -sa $a d j$ & $(\mathrm{Med})$ Que tiene carácter de eritema. & (Med) De(l) eritema o que lo implica. \\
\hline exanguinotransfusión $f$ & $\begin{array}{l}\text { (Med) Sustitución total o parcial de la } \\
\text { sangre de un paciente por la de otro u otros } \\
\text { individuos sanos. }\end{array}$ & (Med) Sustitución de la sangre de una persona. \\
\hline fangoterapia $f$ & $\begin{array}{l}\text { (Med) Tratamiento por aplicación de fango } \\
\text { de aguas medicinales. }\end{array}$ & $\begin{array}{l}\text { (Med) Tratamiento terapeutico por aplicacion } \\
\text { de fango de aguas medicinales. }\end{array}$ \\
\hline farmacoterapia $f$ & $\begin{array}{l}(\mathrm{Med}) \text { Tratamiento de las enfermedades } \\
\text { mediante medicamentos. }\end{array}$ & $\begin{array}{l}\text { (Med) Tratamiento terapéutico mediante } \\
\text { medicamentos. }\end{array}$ \\
\hline fisiopatológico -ca adj & $(M e d)$ De (la) fisiopatología. & (Med) De (la) fisiopatología o de su objeto. \\
\hline fitoterapia $f$ & $\begin{array}{l}\text { (Med }) \text { Tratamiento mediante plantas o } \\
\text { sustancias vegetales. }\end{array}$ & $\begin{array}{l}\text { (Med) Tratamiento terapéutico mediante } \\
\text { plantas o sustancias vegetales. }\end{array}$ \\
\hline flebografía $f$ & $\begin{array}{l}\text { (Med }) \text { Registro del pulso venoso mediante el } \\
\text { flebógrafo. }\end{array}$ & $\begin{array}{l}\text { (Med) Radiografía de las venas y registro del } \\
\text { pulso venoso. }\end{array}$ \\
\hline flebógrafo $m$ & $\begin{array}{l}(\mathrm{Med}) \quad \text { Instrumento para registrar } \\
\text { gráficamente el pulso venoso. }\end{array}$ & (Med) Aparato para realizar flebografías. \\
\hline flebograma $m$ & $(M e d)$ Registro gráfico del pulso venoso. & (Med) Imagen obtenida por el flebógrafo. \\
\hline fototerapia $f$ & $\begin{array}{l}(\mathrm{Med}) \text { Tratamiento de las enfermedades } \\
\text { mediante la acción de la luz, natural o } \\
\text { artificial. }\end{array}$ & $\begin{array}{l}\text { (Med) Tratamiento terapéutico mediante la } \\
\text { acción de la luz, natural o artificial. }\end{array}$ \\
\hline gastroenterológico - ca adj & (Med) De (la) gastroenterología. & (Med) De (la) gastroenterología o de su objeto. \\
\hline
\end{tabular}




\begin{tabular}{|c|c|c|}
\hline granulomatoso -sa adj & $\begin{array}{l}(M e d) \text { De(l) granuloma o que tiene caracteres } \\
\text { de granuloma. }\end{array}$ & $\begin{array}{l}\text { (Med) De(l) granuloma o que lo implica. } \\
2(\text { Med) Que presenta o padece un granuloma. } \\
\text { Tb } n \text {, referido a pers. }\end{array}$ \\
\hline hemoterapia $f$ & $\begin{array}{l}(\mathrm{Med}) \text { Empleo de la sangre como medio } \\
\text { terapéutico. }\end{array}$ & $\begin{array}{l}\text { (Med) Tratamiento basado en el empleo de la } \\
\text { sangre como medio terapéutico. }\end{array}$ \\
\hline hepatológico -ca adj & (Med) De (la) hepatología. & (Med) De (la) hepatologia o de su objeto. \\
\hline hidroterapia $f$ & $\begin{array}{l}(\mathrm{Med}) \text { Empleo del agua en el tratamiento de } \\
\text { enfermedades, especialmente en forma de } \\
\text { abluciones, baños y duchas }\end{array}$ & $\begin{array}{l}\text { (Med) Tratamiento terapeutico basado en el } \\
\text { empleo del agua, esp. en forma de abluciones, } \\
\text { baños y duchas. }\end{array}$ \\
\hline hipoplasia $f$ & $(\mathrm{Med})$ Desarrollo incompleto o defectuoso & $\begin{array}{l}\text { (Biol o Med) Disminución anormal del número } \\
\text { de células de un órgano o tejido. }\end{array}$ \\
\hline hiposmia $f$ & $(M e d)$ Disminución del sentido del olfato. & $\begin{array}{l}\text { (Med) Deficiencia o disminución del sentido } \\
\text { del olfato. }\end{array}$ \\
\hline hormonoterapia $f$ & (Med) Uso terapéutico de las hormonas. & $\begin{array}{l}\text { (Med) Tratamiento terapéutico mediante hor- } \\
\text { monas. }\end{array}$ \\
\hline inmunodeficiente $a d j$ & $\begin{array}{l}(\mathrm{Med}) \text { Que padece inmunodeficiencia. } T b n \text {, } \\
\text { referido a pers. }\end{array}$ & $\begin{array}{l}\text { (Biol) Que presenta inmunodeficiencia. } T b n \text {, } \\
\text { referido a pers }\end{array}$ \\
\hline inmunodepresor -ra adj & $\begin{array}{l}(\mathrm{Med}) \text { [Fármaco] que atenúa o anula las } \\
\text { reacciones de inmunidad del organismo. } T b \\
n \mathrm{~m} \text {. }\end{array}$ & (Biol) Que produce inmunodepresión. $T b n m$. \\
\hline inmunodeprimido - da adj & $\begin{array}{l}(\mathrm{Med}) \text { Que padece deficiencia o atenuación } \\
\text { de las reacciones de inmunidad. } T b n \text {, } \\
\text { referido a pers. }\end{array}$ & $\begin{array}{l}\text { (Biol) Que presenta inmunodepresión. } T b n \text {, } \\
\text { referido a pers. }\end{array}$ \\
\hline laringológico -ca adj & (Med) De (la) laringología. & (Med) De (la) laringologia o de su objeto. \\
\hline laserterapia $f$ & (Med) Uso del láser con fines terapéuticos. & $\begin{array}{l}\text { (Med) Tratamiento terapeutico basado en el } \\
\text { empleo del laser. }\end{array}$ \\
\hline leprógeno -na adj & $\begin{array}{l}(M e d) \text { Que produce o puede ocasionar la } \\
\text { lepra. }\end{array}$ & $\begin{array}{l}\text { (Med) Que produce o puede producir la lepra } \\
{[1] .}\end{array}$ \\
\hline leprológico -ca adj & (Med) De (la) leprología. & (Med) De (la) leprologia o de su objeto. \\
\hline licantrópico - ca adj & (lit y $M e d$ ) De (la) licantropía. & (lit o Med) De (la) licantropia o de(1) licantropo. \\
\hline licántropo -pa $m$ y $f$ & $\begin{array}{l}\text { (lit y } M e d) \text { Hombre en quien se da la } \\
\text { licantropía. }\end{array}$ & $\begin{array}{l}\text { (lit o Med) Pers. que sufre licantropía. Tb adj. } \\
\text { II adj } 2 \text { (lit o Med) De(1) licántropo. }\end{array}$ \\
\hline licor $m$ & 2 (Med o lit) Cuerpo líquido. & $\begin{array}{l}2 \text { (Med o lit) Sustancia liquida. Frec referido al } \\
\text { semen. }\end{array}$ \\
\hline linfa b) & $\begin{array}{l}2 \text { (Fisiol) Líquido [de las pústulas de la } \\
\text { viruela vacuna] b) (Med) Emulsión de linfa, } \\
\text { utilizada para la vacunación antivariólica. }\end{array}$ & $\begin{array}{l}2 \text { (Med) Líquido semejante a la linfa [1]. Con } \\
\text { un adj o compl especificador. b) Emulsión } \\
\text { de linfa, utilizada para la vacunación antiva- } \\
\text { riólica. }\end{array}$ \\
\hline linfático -ca adj & $\begin{array}{l}1 \text { (E) De (la) linfa, esp [1]. Tb } n \text { m, referido } \\
\text { a vaso. }\end{array}$ & $\begin{array}{l}\text { (E)De (la) linfa, esp [1], o que la contiene. } T b n \\
m, \text { referido a vaso.2 (Med) [Pers.] caracterizada } \\
\text { por predominio del sistema linfático [1], poca } \\
\text { presión y tendencia a la obesidad fofa. } T b n . \mathrm{c} \text { ) } \\
\text { (Med o lit) Propio de la pers. linfática. }\end{array}$ \\
\hline linfoma $m$ & $(\mathrm{Med})$ Tumor del tejido linfoide. & (Med) Tumor del tejido linfático [1]. \\
\hline magnetoterapia $f$ & $\begin{array}{l}(\mathrm{Med}) \text { Tratamiento médico basado en el } \\
\text { magnetismo. }\end{array}$ & $\begin{array}{l}\text { (Med) Tratamiento terapéutico basado en el } \\
\text { magnetismo }\left[\begin{array}{lll}1 & \text { y }\end{array}\right] \text {. }\end{array}$ \\
\hline mastoplastia $f$ & $(M e d)$ Cirugía plástica de la mama ${ }^{1}$. & (Med) Mamoplastia \\
\hline mecánico -ca adj & $\begin{array}{l}4(\mathrm{Med})[\text { Asfixia] causada por obstrucción } \\
\text { interna o externa de las vías respiratorias }\end{array}$ & 4 (Med) [Obstrucción] debida a causas físicas. \\
\hline
\end{tabular}




\begin{tabular}{|c|c|c|}
\hline mecanoterapia $f$ & $\begin{array}{l}(\mathrm{Med}) \text { Tratamiento de las enfermedades } \\
\text { mediante aparatos que someten al cuerpo a } \\
\text { un movimiento activo o pasivo. }\end{array}$ & $\begin{array}{l}\text { (Med) Tratamiento terapéutico mediante } \\
\text { aparatos que someten al cuerpo a un } \\
\text { movimiento activo o pasivo. }\end{array}$ \\
\hline mesoterapia $f$ & $\begin{array}{l}\text { (Med) Tratamiento mediante múltiples } \\
\text { inyecciones intradérmicas con pequeñas } \\
\text { dosis de medicamento en la zona afectada. }\end{array}$ & $\begin{array}{l}\text { (Med) Tratamiento terapéutico mediante } \\
\text { múltiples inyecciones intradérmicas con } \\
\text { pequeñas dosis de medicamento en la zona } \\
\text { afectada. }\end{array}$ \\
\hline nefrológico - ca $a d j$ & (Med) De (la) nefrología. & (Med) De (la) nefrología o de su objeto. \\
\hline neonatológico -ca adj. & $(\mathrm{Med})$ De (la) neonatología. & (Med) De (la) neonatología o de su objeto. \\
\hline neumológico -ca adj & (Med) De (la) neumología. & (Med) De (la) neumología o de su objeto. \\
\hline neuroanatómico -ca adj & $\begin{array}{l}\text { (Med) De la neuroanatomía. } \\
\text { II } \mathrm{m} \text { y } \mathrm{f} 2 \quad(\mathrm{Med}) \text { Especialista en } \\
\text { neuroanatomía. }\end{array}$ & $\begin{array}{l}\text { (Med) De la neuroanatomía. } \\
\text { II } m \text { y f } 2 \text { (Med) Neuroanatomista. }\end{array}$ \\
\hline neurólogico -ca $a d j$ & De (la) neurología. & (Med) De (la) neurología o de su objeto. \\
\hline nosografía $f$ & $\begin{array}{l}\text { (Med) Clasificación y descripción de las } \\
\text { enfermedades. }\end{array}$ & $\begin{array}{l}\text { (Med) Descripción y clasificación de las } \\
\text { enfermedades. }\end{array}$ \\
\hline nosográfico -ca adj & (Med) De (la) nosografía. & (Med) De (la) nosografía o de su objeto. \\
\hline nosológico -ca adj & (Med) De (la) nosología. & (Med) De (la) nosología o de su objeto. \\
\hline obliterante adj & $\begin{array}{l}(\mathrm{Med}) \text { [Arteriosclerosis] que produce } \\
\text { obliteración progresiva de las arterias }\end{array}$ & (Med) Que oblitera [1]. \\
\hline odontológico -ca adj & De (la) odontología. & (Med) De (la) odontología o de su objeto. \\
\hline oftalmológico -ca adj & (Med) De (la) oftalmología. & (Med) (De (la) oftalmología o de su objeto. \\
\hline oncogénesis $f$ & $(\mathrm{Med})$ Formación de tumores. & (Med) Formación de tumores y esp. cáncer. \\
\hline oncógeno -na adj & (Med) Que forma tumores. & (Med) Que forma tumores y esp. cáncer. \\
\hline oncología $f$ & $\begin{array}{l}(M e d) \text { Especialidad médica que estudia los } \\
\text { tumores. }\end{array}$ & $\begin{array}{l}\text { (Med) Especialidad médica que estudia los } \\
\text { tumores y esp. el cáncer. }\end{array}$ \\
\hline oncológico -ca adj & $\begin{array}{l}(M e d) \text { I De (la) oncología. } 2(\mathrm{Med}) \text { Que } \\
\text { padece un tumor. }\end{array}$ & $\begin{array}{l}\text { (Med) De (la) oncología o de su objeto. } 2(\mathrm{Med}) \\
\text { Que padece un tumor y esp. cáncer. }\end{array}$ \\
\hline onicofagia $f$ & $(M e d)$ Hábito de morderse las uñas. & (Med) Hábito morboso de morderse las uñas. \\
\hline organoterapia $f$ & $\begin{array}{l}(\mathrm{Med}) \text { Tratamiento con jugos o extractos de } \\
\text { órganos animales. }\end{array}$ & $\begin{array}{l}\text { (Med, hoy raro) Tratamiento terapéutico con } \\
\text { jugos o extractos de órganos [1] animales. }\end{array}$ \\
\hline otológico -ca adj & (Med) De (la) otología. & (Med) De (la) otología o de su objeto. \\
\hline papuloso -sa adj & $\begin{array}{l}(M e d) \text { Que se caracteriza por la presencia de } \\
\text { pápulas. }\end{array}$ & (Med) De (las) pápulas o que las implica. \\
\hline patológico -ca adj $\neg$ & $\begin{array}{l}\text { De (la) patología. b) De (la) enfermedad o } \\
\text { que la implica. }\end{array}$ & $\begin{array}{l}\text { (Med) De (la) patología o de su objeto. b) De } \\
\text { (la) enfermedad o que la implica. }\end{array}$ \\
\hline pelagroso -sa adj & [Pers] que padece pelagra. $T b n$ & $\begin{array}{l}\text { (Med) De (la) pelagra o que la implica. } 2 \text { (Med) } \\
\text { Que padece pelagra. } T b \text {, referido a pers. }\end{array}$ \\
\hline podológico -ca $a d j \neg$ & De (la) podología. & (Med) De (la) podología o de su objeto. \\
\hline presoterapia $f$ & $\begin{array}{l}\text { (Med) Tratamiento destinado a eliminar los } \\
\text { líquidos acumulados en las piernas, medi- } \\
\text { ante la introducción de estas en un aparato } \\
\text { a modo de bota. }\end{array}$ & $\begin{array}{l}\text { (Med) Tratamiento destinado a eliminar los } \\
\text { líquidos acumulados en el cuerpo, esp. en las } \\
\text { piernas, mediante un aparato neumático que se } \\
\text { infla y desinfla alternativamente. }\end{array}$ \\
\hline proctológico -ca adj & (Med) De (la) proctología. & (Med) De (la) proctología o de su objeto. \\
\hline $\begin{array}{l}\text { psicopático -ca ( } t b, \quad \text { más } \\
\text { raro, sicopático) adj }\end{array}$ & $\begin{array}{l}\text { (Med) } 1 \text { De (la) psicopatía. } 2 \text { (Med) Que } \\
\text { padece psicopatía. } T b n .\end{array}$ & $\begin{array}{l}\text { (Med) De (la) psicopatía o que la implica. } 2 \\
\text { (Med, raro) Que padece psicopatía. } T b n \text {. }\end{array}$ \\
\hline
\end{tabular}




\begin{tabular}{|c|c|c|}
\hline $\begin{array}{l}\text { psicopatológico }-\mathrm{ca} \quad(t b, \\
\text { raro, sicopatológico }) a d j\end{array}$ & (Med) De (la) psicopatología. & (Med) De (la) psicopatología o de su objeto. \\
\hline punticular adj & $(\mathrm{Med})$ [Fiebre] maligna con manchas. & $\begin{array}{l}\text { (Med) [Fiebre (enfermedad)] maligna con } \\
\text { manchas. }\end{array}$ \\
\hline pustuloso -sa adj & $\begin{array}{l}(\mathrm{Med}) \text { Caracterizado por la presencia de } \\
\text { pústulas. }\end{array}$ & $\begin{array}{l}\text { (Med) De (las) pústulas o que las implica. } 2 \\
\text { (Med) Que tiene pústulas. Tb } n \text {, referido a } \\
\text { pers. }\end{array}$ \\
\hline quimioterapia $f$ & $\begin{array}{l}(\mathrm{Med}) \text { Tratamiento mediante sustancias } \\
\text { químicas. Esp con referencia al cáncer. }\end{array}$ & $\begin{array}{l}\text { (Med) Tratamiento terapéutico mediante } \\
\text { sustancias químicas [1]. Esp con referencia } \\
\text { al cáncer. }\end{array}$ \\
\hline $\begin{array}{l}\text { radiofotografiar (conjug 1c) } \\
t r\end{array}$ & $(\mathrm{Med})$ Someter a radiofotografía. & $\begin{array}{l}(M e d) \text { Obtener la imagen radiofotográfica [de } \\
\text { alguien o algo }(c d)] \text {. }\end{array}$ \\
\hline radiológico -ca adj & De (la) radiología. & (Med) De (la) radiología o de su objeto. \\
\hline radiumterapia $f$ & $(\mathrm{Med})$ Empleo terapéutico del radio ${ }^{2}$. & $\begin{array}{l}\text { (Med) Tratamiento terapéutico basado en el } \\
\text { empleo del radio2. }\end{array}$ \\
\hline rectoscopia $f$ & $\begin{array}{l}(\mathrm{Med}) \text { Examen visual del intestino recto por } \\
\text { vía rectal }\end{array}$ & $\begin{array}{l}(\mathrm{Med}) \text { Examen visual del recto [5d] por vía } \\
\text { rectal. }\end{array}$ \\
\hline reflexológico -ca adj & $(M e d)$ De la reflexología. & (Med) De la reflexología o de su objeto. \\
\hline reflexoterapia $f$ & $\begin{array}{l}(\mathrm{Med}) \text { Utilización terapéutica de los reflejos } \\
\text { condicionados. }\end{array}$ & $\begin{array}{l}\text { (Med) Tratamiento terapéutico basado en los } \\
\text { reflejos condicionados. }\end{array}$ \\
\hline retractar $t r$ & $(\mathrm{Med})$ Retraerse [4] & $(\mathrm{Med})$ Retraerse [4] o sufrir retracción [2]. \\
\hline reumatólogico -ca $m$ y $f$ & De la reumatología. & (Med) De (la) reumatología o de su objeto. \\
\hline rinología $f$ & $\begin{array}{l}\text { Especialidad médica que versa sobre la } \\
\text { nariz. }\end{array}$ & $\begin{array}{l}\text { (Med) Especialidad médica que trata de la } \\
\text { nariz y sus enfermedades. }\end{array}$ \\
\hline rinológico -ca adj & De (la) rinología o de su objeto. & (Med) De (la) rinología o de su objeto. \\
\hline sanioso -sa adj & $(\mathrm{Med}) \mathrm{De}(1)$ icor. & $\begin{array}{l}\text { (Med) De(l) icor (líquido fétido de una llaga } \\
\text { o úlcera). }\end{array}$ \\
\hline seborreico-ca adj & $\begin{array}{l}(\mathrm{Med}) \text { De (la) seborrea. } 2(\mathrm{Med}) \text { Que padece } \\
\text { seborrea. } T b n \text {. }\end{array}$ & $\begin{array}{l}\text { (Med) De (la) seborrea o que la implica. } 2 \text { (Med) } \\
\text { Que padece seborrea. } T b n \text {. }\end{array}$ \\
\hline sociópata $m$ y $f$ & $\begin{array}{l}(\mathrm{Med}) \text { Enfermo mental caracterizado por } \\
\text { comportamientos contrarios a la sociedad. }\end{array}$ & $\begin{array}{l}\text { (Med) [Pers.] que padece una sociopatía. } \\
\text { Frec } n .\end{array}$ \\
\hline sofrológico -ca adj & $(\mathrm{Med}) \mathrm{De}(\mathrm{la})$ sofrología. & (Med) De (la) sofrología o de su objeto. \\
\hline tanatológico -ca adj & $(\mathrm{Med})$ De la tanatología. & (Med) De (la) tanatología o de su objeto. \\
\hline \multirow[t]{2}{*}{ terapéutico -ca adj } & 1 De (la) terapéutica. & $\begin{array}{l}\text { I (Med) De (la) terapéutica [2] o que sirve para } \\
\text { tratar enfermedades. }\end{array}$ \\
\hline & $\begin{array}{l}\text { II f } 2 \text { Tratamiento } \mathrm{o} \text { curación de } \\
\text { enfermedades. }\end{array}$ & $\begin{array}{l}\text { II } f 2 \text { (Med) Tratamiento o curación de } \\
\text { enfermedades. }\end{array}$ \\
\hline terapia $f$ & Terapéutica [2]. & $\begin{array}{l}\text { (Med) Tratamiento de una enfermedad. Frec } \\
\text { con un adj o compl especificador. Tb fig., fuera } \\
\text { del ámbito técn. b) Psicoterapia (tratamiento de } \\
\text { las enfermedades, esp. mentales, por métodos } \\
\text { psicológicos). }\end{array}$ \\
\hline termoterapia $f$ & (Med) Aplicación terapéutica del calor. & $\begin{array}{l}\text { (Med) Tratamiento terapéutico mediante el } \\
\text { calor. }\end{array}$ \\
\hline tiflología $f$ & $\begin{array}{l}(M e d) \text { Parte de la medicina que estudia la } \\
\text { ceguera. }\end{array}$ & (Med) Estudio de la ceguera. \\
\hline tocoginecológico - ca adj & $(\mathrm{Med}) \mathrm{De}(\mathrm{la})$ tocoginecología. & (Med) De (la) tocoginecología o de su objeto. \\
\hline tofoso - sa adj & $(\mathrm{Med})$ Que tiene o implica tofos. & $\begin{array}{l}\text { (Med) De (los) tofos o que los implica. } 2 \text { (Med) } \\
\text { Que tiene tofos. }\end{array}$ \\
\hline
\end{tabular}




\begin{tabular}{|c|c|c|}
\hline tracomatoso -sa adj & $\begin{array}{l}(M e d) \text { De(l) tracoma. } 2(\mathrm{Med}) \text { Que padece } \\
\text { tracoma. }\end{array}$ & $\begin{array}{l}(\mathrm{Med}) \mathrm{De}(\mathrm{l}) \text { tracoma o que lo implica. } 2(\mathrm{Med}) \\
\text { Que padece tracoma. } T b \text {, referido a pers. }\end{array}$ \\
\hline transferencia $f$ & $\begin{array}{l}2(\text { Med }) \text { Vinculación afectiva, frec. de } \\
\text { carácter sexual, entre el paciente de una cura } \\
\text { psicoanalítica y el médico que le trata. }\end{array}$ & $\begin{array}{l}2 \text { (Psicol) Fenómeno por el que un sujeto } \\
\text { proyecta sobre una pers. o cosa un estado } \\
\text { afectivo experimentado previamente en } \\
\text { relación con otra. Frec. referido a la relación } \\
\text { médico-enfermo. }\end{array}$ \\
\hline ulcerativo -va adj & Que produce úlcera. & (Med o lit) Que produce o implica úlcera. \\
\hline urografía $\mathrm{f}$ & $\begin{array}{l}\text { (Med) Radiografía (procedimiento o } \\
\text { fotografía) de las vías urinarias. }\end{array}$ & (Med) Radiografía de las vías urinarias. \\
\hline urológico -ca adj & De la urología. & (Med) De la urología o de su objeto. \\
\hline venereológico -ca adj & $(\mathrm{Med}) \mathrm{De}(\mathrm{la})$ venereología. & (Med) De (la) venereología o de su objeto. \\
\hline ventiloterapia $f$ & (Med) Terapia ventilatoria. & $\begin{array}{l}\text { (Med) Tratamiento terapéutico mediante } \\
\text { ventilación asistida. }\end{array}$ \\
\hline
\end{tabular}

\section{ANEXO V}

Cambio en la marcación

\begin{tabular}{|c|c|c|}
\hline VOCABLO & 1. ${ }^{\text {a }}$ EDICIÓN & 2. ${ }^{a}$ EDICIÓN \\
\hline álalo -la ( $t b$ alalo $) a d j$ & $\begin{array}{l}\text { (Med) Que padece alalia. Tb fig, fuera del } \\
\text { ámbito técn. }\end{array}$ & (Med o lit) Que padece alalia. \\
\hline acceso $m$ & $\begin{array}{l}2 \text { Acometida repentina de un estado físico } \\
\text { o moral. }\end{array}$ & $\begin{array}{l}\text { 4. (Med) Acometida repentina de un estado } \\
\text { físico o moral. }\end{array}$ \\
\hline acrofobia $f$ & (Med) Temor morboso a estar a gran altura & (Psicol) Temor morboso a estar a gran altura \\
\hline aerofobia $f$ & (Med) Temor morboso al aire & (Psicol) Temor morboso al aire o a la altura. \\
\hline agorafobia $f$ & $\begin{array}{l}\text { (lit o Med) Temor u aversión a los espacios } \\
\text { abiertos. }\end{array}$ & $\begin{array}{l}\text { (lit o Psicol) Temor u aversión a los espacios } \\
\text { abiertos o públicos. }\end{array}$ \\
\hline amiloide $a d j$ & $\begin{array}{l}\text { (Quim y Med) } 1 \text { [Sustancia] proteica de } \\
\text { naturaleza o aspecto de almidón. Frec } \\
n \text { m, esp designando la que se deposita } \\
\text { en los tejidos de ciertos órganos en } \\
\text { determinadas enfermedades. } 2 \text { Relativo a } \\
\text { la sustancia amiloide [1]. }\end{array}$ & $\begin{array}{l}\text { (Quim y Med) [Sustancia] proteica de } \\
\text { naturaleza o aspecto de almidón. Frec } n \text { m, } \\
\text { esp designando la que se deposita en los } \\
\text { tejidos de ciertos órganos en determinadas } \\
\text { enfermedades. } 2 \text { (Quim y Med) Relativo a la } \\
\text { sustancia amiloide [1]. }\end{array}$ \\
\hline angina de pecho $f$ & $\begin{array}{l}\text { Síndrome debido a una insuficiencia } \\
\text { coronaria, que se manifiesta por un dolor } \\
\text { agudo en el pecho y una intensa sensación } \\
\text { de angustia. } T b \text { (raro) simplemente angina. }\end{array}$ & $\begin{array}{l}\text { Síndrome debido a una insuficiencia coronaria, } \\
\text { que se manifiesta por un dolor agudo en el pecho } \\
\text { y una intensa sensación de angustia. } T b(\mathrm{Med}) \\
\text { simplemente angina. }\end{array}$ \\
\hline antibioticoterapia $f$ & Tratamiento con antibióticos. & (Med) Tratamiento terapéutico con antibióticos. \\
\hline antifebril adj & $\begin{array}{l}\text { Que rebaja la fiebre. Tb } n \text { m, referido a } \\
\text { medicamento o remedio. }\end{array}$ & $\begin{array}{l}(\mathrm{Med}) \text { Antipirético (que reduce o elimina la } \\
\text { fiebre). } T b n \mathrm{~m}\end{array}$ \\
\hline antigangrenoso $-\mathrm{sa} a d j$ & $\begin{array}{l}\text { Eficaz contra la gangrena. } T b \mathrm{n} m \text {, referido } \\
\text { a medicamento o remedio. }\end{array}$ & $\begin{array}{l}(\mathrm{Med}) \text { Eficaz contra la gangrena. Tb } n \mathrm{~m} \text {, } \\
\text { referido a medicamento o remedio }\end{array}$ \\
\hline antihistérico -ca adj & $\begin{array}{l}\text { Eficaz contra la histeria. } T b \mathrm{n} m \text {, referido a } \\
\text { medicamento o remedio. }\end{array}$ & $\begin{array}{l}(\mathrm{Med}) \text { Eficaz contra la histeria. } \mathrm{Tb} n \mathrm{~m} \text {. referido } \\
\text { a medicamento o remedio. }\end{array}$ \\
\hline antipalúdico -ca adj & $\begin{array}{l}\text { [Cosa] destinada a combatir el paludismo. } \\
T b \text {, referido a medicamento o remedio. }\end{array}$ & $\begin{array}{l}(\mathrm{Med})[\mathrm{Cosa}] \text { destinada a combatir el paludismo. } \\
T b \text {, referido a medicamento o remedio. }\end{array}$ \\
\hline antropofobia $f$ & $\begin{array}{l}(\mathrm{Med}) \text { Temor o aversión enfermizos por la } \\
\text { presencia humana. }\end{array}$ & $\begin{array}{l}\text { (Psicol) Temor o aversión enfermizos por la } \\
\text { presencia humana. }\end{array}$ \\
\hline
\end{tabular}




\begin{tabular}{|c|c|c|}
\hline apoplejía $f$ & $\begin{array}{l}\text { Abolición de las funciones cerebrales } \\
\text { producida por embolia o por hemorragia } \\
\text { cerebral. }\end{array}$ & $\begin{array}{l}(\mathrm{Med}) \text { Abolición de las funciones cerebrales } \\
\text { producida por embolia o por hemorragia } \\
\text { cerebral. }\end{array}$ \\
\hline apopléjico & $\begin{array}{l}\text { De la apoplejía 2. Que padece apoplejía. } \\
\operatorname{Tb} n \text {. }\end{array}$ & $(M e d)$ Apoplético \\
\hline apoplético -ca adj & No se incluye. & $\begin{array}{l}\text { (Med) De (la) apoplejía. } 2 \text { (Med) Que padece } \\
\text { apoplejía. } T b n .\end{array}$ \\
\hline arteriosclerótico, -ca adj & $\begin{array}{l}\text { De (la) arteriosclerosis. } 2 \text { Que padece } \\
\text { arteriosclerosis. } T b n \text {, referido a pers. } T b \\
\text { fig. }\end{array}$ & $\begin{array}{l}\text { (Med) De (la) arteriosclerosis. } 2 \text { (Med) Que } \\
\text { padece arteriosclerosis. } T b \text {, referido a pers. } \\
\text { Tb fig. }\end{array}$ \\
\hline $\operatorname{artrosis} f$ & $\begin{array}{l}\text { Afección articular crónica, de naturaleza } \\
\text { degenerativa no inflamatoria. }\end{array}$ & $\begin{array}{l}\text { (Med) Afección articular crónica, de naturaleza } \\
\text { degenerativa no inflamatoria. }\end{array}$ \\
\hline actinomicosis $f \neg$ & $\begin{array}{l}\text { Enfermedad crónica infecciosa propia } \\
\text { especialmente del ganado vacuno, causada } \\
\text { por un actinomices y caracterizada por la } \\
\text { formación de tumores en las mandíbulas y } \\
\text { en la lengua. }\end{array}$ & $\begin{array}{l}\text { (Med) Enfermedad crónica infecciosa propia } \\
\text { especialmente del ganado vacuno, causada por } \\
\text { un actinomices y caracterizada por la formación } \\
\text { de tumores en las mandíbulas y en la lengua. }\end{array}$ \\
\hline aerofobia $f$ & $(\mathrm{Med})$ Temor morboso al aire & (Psicol) Temor morboso al aire o a la altura \\
\hline agorafobia $f$ & $\begin{array}{l}\text { (lit o Med) Temor u aversión a los espacios } \\
\text { abiertos. }\end{array}$ & $\begin{array}{l}\text { (lit o Psicol) Temor u aversión a los espacios } \\
\text { abiertos o públicos }\end{array}$ \\
\hline alálico -ca adj & (Med) Álalo. $T b n$. & $\begin{array}{l}\text { (Med o lit) De la alalia o que la implica. 2. (Med } \\
\text { o lit) Álalo. } T b n \text {. }\end{array}$ \\
\hline biotípico -ca adj & (Biol y $\mathrm{Med}$ ) De)1) biotipo. & (Biol y Psicol) De(l( biotipo. \\
\hline bipolaridad $f$ & (E) Condición de bipolar. & (E o Med) Condición de bipolar. \\
\hline bronco- pref. & De los bronquios & (Med) De los bronquios. \\
\hline cancerología $f$ & Estudio y tratamiento del cáncer. & $(M e d)$ Estudio y tratamiento del cáncer. \\
\hline cancerológico -ca adj & De la cancerología o de su objeto. & (Med) De la cancerología o de su objeto. \\
\hline cancerólogo -ga $m$ y $f$ & Especialista en cancerología. & (Med) Especialista en cancerología. \\
\hline cretínico -ca adj & $(M e d)$ De(l) cretinismo. 2 De(l) cretino. & $(\mathrm{Med}) \mathrm{De}(1)$ cretinismo. 2. (Med) De(1) cretino. \\
\hline criptorquídico -ca $a d j$ & $\begin{array}{l}\text { (Med) De (la) criptorquidia. } 2 \text { Que padece } \\
\text { criptorquidia. Tb n. }\end{array}$ & $\begin{array}{l}\text { (Med) De (la) criptorquidia. 2.(Med) Que padece } \\
\text { criptorquidia. Tb n. }\end{array}$ \\
\hline $\begin{array}{l}\text { curieterapia } \quad(\text { pronunc } \\
\text { corriente, /kuriterápia/) } f\end{array}$ & (Med) Radiumterapia. & (Med, hoy raro) Radiumterapia. \\
\hline dartros $m$ & $\begin{array}{l}\text { Enfermedad de la piel, esp. eccema, } \\
\text { herpes o psoriasis. }\end{array}$ & $\begin{array}{l}\text { (Med) Enfermedad de la piel, esp. eccema, } \\
\text { herpes o psoriasis. }\end{array}$ \\
\hline dermatología $f$ & $\begin{array}{l}\text { Parte de la medicina que estudia las } \\
\text { enfermedades de la piel. }\end{array}$ & $\begin{array}{l}\text { (Med) Parte de la medicina que estudia las } \\
\text { enfermedades de la piel. }\end{array}$ \\
\hline dermatológico -ca adj & De (la) dermatología. & (Med) De (la) dermatología o de su objeto. \\
\hline dermatólogo -ga $m$ y $f$ & Especialista en dermatología. & $(\mathrm{Med})$ Especialista en dermatología \\
\hline $\operatorname{disosmia} f$ & Alteración del sentido del olfato. & (Med) Alteración del sentido del olfato \\
\hline $\begin{array}{l}\text { eccematoso }-\mathrm{sa} \text { (tb con la } \\
\text { grafía eczematoso) } a d j\end{array}$ & De(1) eccema. & $\begin{array}{l}\text { (Med) De(l) eccema o que lo implica. } 2 \text { (Med) } \\
\text { Que padece eccema. Tb } n \text {, referido a pers }\end{array}$ \\
\hline ecografía $f$ & $\begin{array}{l}\text { Técnica médica que utiliza los ultrasonidos } \\
\text { en el examen del interior del cuerpo. Tb el } \\
\text { examen y la imagen correspondiente. }\end{array}$ & $\begin{array}{l}(M e d) \text { Técnica que utiliza los ultrasonidos en el } \\
\text { examen del interior del cuerpo. Tb el examen y } \\
\text { la imagen correspondiente }\end{array}$ \\
\hline ecográfico -ca adj & De (la) ecografía. & (Med) De (la) ecografía. \\
\hline electrocardiograma $m$ & Gráfico obtenido por el electrocardiógrafo. & (Med) Gráfico obtenido por el electrocardiógrafo. \\
\hline
\end{tabular}




\begin{tabular}{|c|c|c|}
\hline eritrofobia $f$ & $\begin{array}{l}(M e d) \text { Temor a ruborizarse, que va } \\
\text { acompañado de enrojecimiento facial. }\end{array}$ & $\begin{array}{l}\text { (Psicol) Temor a ruborizarse, que va acompañado } \\
\text { de enrojecimiento facial. }\end{array}$ \\
\hline escrofuloso -sa adj & Que padece escrófula. $T b n . T b$ (lit) fig. & $\begin{array}{l}\text { (Med) De (la) escrófula. } 2 \text { (Med) Que padece } \\
\text { escrófula. } T b n \text {, referido a pers. Tb (lit) fig. }\end{array}$ \\
\hline estomatólogo-ga $m$ y $f$ & Especialista en estomatología. & $(\mathrm{Med})$ Especialista en estomatología. \\
\hline fitoterapeuta $m$ y $f$ & Especialista en fitoterapia. & $(\mathrm{Med})$ Especialista en fitoterapia. \\
\hline $\operatorname{gota}^{2} f$ & $2 \sim$ serena. Amaurosis & $2 \sim$ serena. (Med) Amaurosis. \\
\hline gotoso -sa adj & Que padece gota. $T b n$, referido a pers. & $\begin{array}{l}\text { (Med) De la gota }{ }^{2} \text { o que la implica. } 2 \text { (Med) } \\
\text { Que padece gota }{ }^{2} . T b n \text {, referido a pers. }\end{array}$ \\
\hline hematolísico -ca adj & (Fisiol) De (la) hematolisis. & (Med) De (la) hematolisis. \\
\hline hemiplejía (tb hemiplejia) $f$ & Parálisis de un lado del cuerpo. & (Med) Parálisis de un lado del cuerpo. \\
\hline $\begin{array}{l}\text { infectocontagioso }-\mathrm{sa} \text { (tb con } \\
\text { la grafía infecto-contagioso) } \\
\text { adj }\end{array}$ & $\begin{array}{l}\text { [Enfermedad] infecciosa contagiosa. } 2 \text { Que } \\
\text { padece una enfermedad infectocontagiosa } \\
\text { [1]. }\end{array}$ & $\begin{array}{l}\text { (Med) [Enfermedad] infecciosa contagiosa. } \\
2(\mathrm{Med}) \text { Que padece una enfermedad } \\
\text { infectocontagiosa [1]. }\end{array}$ \\
\hline inmune adj & $\begin{array}{l}2(\mathrm{Med}) \text { Que presenta inmunidad. Frec con } \\
\text { un compl } A .3(\mathrm{Med}) \text { De (la) inmunidad }\end{array}$ & $\begin{array}{l}2 \text { (Biol) Que presenta inmunidad. Frec con un } \\
\text { compl A. } 3 \text { (Biol) De (la) inmunidad. }\end{array}$ \\
\hline inmunidad $f$ & $\begin{array}{l}2(\mathrm{Med}) \text { Resistencia de un organismo a } \\
\text { una enfermedad o a la acción patógena } \\
\text { de determinados gérmenes o sustancias. } A \\
\text { veces con un compl } A \text {. }\end{array}$ & $\begin{array}{l}2 \text { (Biol) Resistencia de un organismo a } \\
\text { una enfermedad o a la acción patógena de } \\
\text { determinados gérmenes o sustancias. A veces } \\
\text { con un compl } A \text {. }\end{array}$ \\
\hline inmunitario -ria $a d j$ & (Med) De (la) inmunidad. & 2 (Biol) De (la) inmunidad. \\
\hline inmunización $f$ & $(M e d)$ Acción de inmunizar. Tb su efecto. & 2 (Biol) Acción de inmunizar. Tb su efecto. \\
\hline inmunizador -ra adj & $(\mathrm{Med})$ Que inmuniza & (Biol) Que inmuniza. \\
\hline inmunizante $a d j$ & $\begin{array}{l}(\mathrm{Med}) \text { [Cosa] que inmuniza. } 2 \text { (Med) } \\
\text { Relativo a la acción de inmunizar }\end{array}$ & $\begin{array}{l}\text { (Biol) [Cosa] que inmuniza. } 2 \text { (Biol) Relativo a } \\
\text { la acción de inmunizar }\end{array}$ \\
\hline inmunizar $t r$ & $\begin{array}{l}\text { (Med) Hacer [a alguien (cd)] inmune [a } \\
\text { algo (compl CONTRA, DE o PARA)]. Tb } \\
\text { fig, fuera del ámbito técn. }\end{array}$ & $\begin{array}{l}\text { (Biol) Hacer [a alguien (cd)] inmune [a algo } \\
\text { (compl CONTRA, DE o PARA)]. Tb fig, fuera } \\
\text { del ámbito técn. }\end{array}$ \\
\hline inmunodeficiente $a d j$ & $\begin{array}{l}\text { (Med) Que padece inmunodeficiencia. } T b \\
\text { n, referido a pers. }\end{array}$ & $\begin{array}{l}\text { (Biol) Que presenta inmunodeficiencia } T b n \text {, } \\
\text { referido a pers. }\end{array}$ \\
\hline inmunodepresor-ra $a d j$ & $\begin{array}{l}(\mathrm{Med}) \text { [Fármaco] que atenúa o anula las } \\
\text { reacciones de inmunidad del organismo. } \\
T b \mathrm{n} \mathrm{m} \text {. }\end{array}$ & (Biol) Que produce inmudopresión. $T b n m$. \\
\hline inmunodeprimido - da adj & $\begin{array}{l}(M e d) \text { Que padece deficiencia o atenuación } \\
\text { de las reacciones de inmunidad. Tb n, } \\
\text { referido a pers. }\end{array}$ & $\begin{array}{l}\text { (Biol) Que presenta inmunodepresion. } T b n \text {, } \\
\text { referido a pers. }\end{array}$ \\
\hline inmunofluorescencia $f$ & $\begin{array}{l}\text { (Med) Prueba inmunológica que consiste } \\
\text { en teñir con un colorante fluorescente un } \\
\text { antígeno o un anticuerpo para localizar el } \\
\text { anticuerpo o el antígeno correspondiente. }\end{array}$ & $\begin{array}{l}\text { (Biol) Prueba inmunológica que consiste en } \\
\text { teñir con un colorante fluorescente un antígeno } \\
\text { o un anticuerpo para localizar el anticuerpo o } \\
\text { el antígeno correspondiente. }\end{array}$ \\
\hline inmunógeno -na adj & $(\mathrm{Med})$ Que produce inmunidad. & (Biol) Que produce inmunidad. \\
\hline inmunohematología $f$ & $\begin{array}{l}\text { (Med) Estudio de las propiedades } \\
\text { inmunológicas de la sangre. }\end{array}$ & $\begin{array}{l}\text { (Biol) Estudio de las propiedades inmunológicas } \\
\text { de la sangre. }\end{array}$ \\
\hline inmunología $f$ & $\begin{array}{l}\text { (Med) Estudio de los fenómenos de la } \\
\text { inmunidad. }\end{array}$ & (Biol) Estudio de los fenómenos de la inmunidad. \\
\hline inmunológico -ca adj & $\begin{array}{l}\text { (Med) De (la) inmunología.*Estudios } \\
\text { inmunológicos. } 2(\mathrm{Med}) \text { De (la) inmunidad. }\end{array}$ & 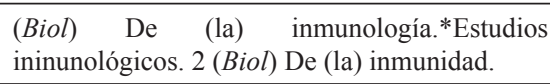 \\
\hline inmunólogo -ga $m$ y $f$ & $(M e d)$ Especialista en inmunología. & (Biol) Especialista en inmunología \\
\hline
\end{tabular}




\begin{tabular}{|c|c|c|}
\hline inmunoprecipitación $f$ & $\begin{array}{l}(M e d) \text { Precipitación de un anticuerpo y su } \\
\text { antígeno correspondiente. }\end{array}$ & $\begin{array}{l}\text { (Biol) Precipitación de un anticuerpo y su } \\
\text { antígeno correspondiente }\end{array}$ \\
\hline inmunosupresión $f$ & $\begin{array}{l}(M e d) \text { Suspensión artificial de la reacción } \\
\text { de inmunidad consecutiva a una acción } \\
\text { terapéutica. }\end{array}$ & $\begin{array}{l}\text { (Biol) Suspensión artificial de la reacción } \\
\text { de inmunidad consecutiva a una acción } \\
\text { terapéutica }\end{array}$ \\
\hline inmunosupresor -ra $a d j$ & $\begin{array}{l}(\mathrm{Med}) \quad[\text { Fármaco }] \text { que produce } \\
\text { inmunosupresión. Tb } \mathrm{n} \mathrm{m.}\end{array}$ & $\begin{array}{l}\text { (Biol) [Fármaco] que produce inmunosupresión. } \\
T b n m \text {. }\end{array}$ \\
\hline kala-azar $m$ & $\begin{array}{l}\text { Enfermedad infecciosa tropical causada } \\
\text { por el protozoo Leishmania donovani y } \\
\text { caracterizada por fiebre, enflaquecimiento } \\
\text { e hipertrofia del bazo y del hígado. }\end{array}$ & $\begin{array}{l}\text { (Med) Enfermedad infecciosa tropical causada } \\
\text { por el protozoo Leishmania donovani y } \\
\text { caracterizada por fiebre, enflaquecimiento e } \\
\text { hipertrofia del bazo y del hígado. }\end{array}$ \\
\hline lámpara de cuarzo $f$ & $\begin{array}{l}(\mathrm{Med}) \text { Dispositivo para la aplicación } \\
\text { terapéutica de rayos ultravioletas. }\end{array}$ & $\begin{array}{l}\text { Dispositivo para la aplicación terapéutica de } \\
\text { rayos ultravioletas. }\end{array}$ \\
\hline $\operatorname{linfa} f$ & $\begin{array}{l}2 \text { (Fisiol) Líquido [de las púsutlas de la } \\
\text { viruela vacuna] b) (Med) Emulsión de linfa, } \\
\text { utilizada para la vacunación antivariólica. }\end{array}$ & $\begin{array}{l}2 \text { (Med) LÍquido semejante a la linfa [1]. Con } \\
\text { un adj o compl especificador. b) Emulsión de } \\
\text { linfa, utilizada para la vacunación antivariólica. }\end{array}$ \\
\hline linfocítico - ca adj & (Anat) Linfocitario. & (Anat o Med) Linfocitario. \\
\hline logoterapia $f$ & $\begin{array}{l}(M e d) \text { Tratamiento psicoterapéutico de } \\
\text { las neurosis elaborado por V. E. Frankl. } 2 \\
\text { Logopedia }\end{array}$ & $\begin{array}{l}(M e d) \text { Tratamiento psicoterapéutico de las } \\
\text { neurosis elaborado por V. E. Frankl. } 2 \text { (Med) } \\
\text { Logopedia. }\end{array}$ \\
\hline lupus $m$ & $\begin{array}{l}\text { Enfermedad de la piel o de las mucosas } \\
\text { caracterizada por la producción de } \\
\text { tubérculos que se ulceran y por su tendencia } \\
\text { a la extensión. }\end{array}$ & $\begin{array}{l}\text { (Med) Enfermedad de la piel o de las mucosas } \\
\text { caracterizada por la producción de tubérculos } \\
\text { que se ulceran y por su tendencia a la extensión. }\end{array}$ \\
\hline malariólogo -ga $m$ y $f$ & Especialista en malariología. & (Med) Especialista en malariología. \\
\hline maníaco -ca ( $t b$ maniaco) adj & (Med) 1 De (la) manía. 2 Que padece manía & (Med). De (la) manía. 2 (Med) Que padece manía \\
\hline meningítico -ca adj & $\begin{array}{l}\text { (Med) De (la) meningitis. } 2 \text { [Pers.1 que } \\
\text { padece meningitis. Tb } n . \text { b) [Pers.] que } \\
\text { presenta secuelas de haber padecido } \\
\text { meningitis.Tb } n \text {. Frec fig, aludiendo a } \\
\text { deficiencia mental. }\end{array}$ & $\begin{array}{l}\text { (Med) De (la) meningitis. } 2 \text { (Med) [Pers.l que } \\
\text { padece meningitis. } T b n . \text { b) [Pers.] que presenta } \\
\text { secuelas de haber padecido meningitis. } T b n \text {. } \\
\text { Frec fig, aludiendo a deficiencia mental. }\end{array}$ \\
\hline mongolismo $\mathrm{m}$ & $\begin{array}{l}\text { Anomalía congénita que se manifiesta } \\
\text { por el aspecto mongoloide del rostro y } \\
\text { un retraso mental que puede llegar hasta } \\
\text { la idiotez. }\end{array}$ & $\begin{array}{l}\text { (Med) Anomalía congénita que se manifiesta } \\
\text { por el aspecto mongoloide del rostro y un } \\
\text { retraso mental que puede llegar hasta la idiotez. }\end{array}$ \\
\hline musicoterapia $f$ & $\begin{array}{l}\text { Tratamiento terapéutico mediante la } \\
\text { música. }\end{array}$ & $\begin{array}{l}\text { (Med) Tratamiento terapéutico mediante la } \\
\text { música. }\end{array}$ \\
\hline neurología $f$ & $\begin{array}{l}\text { Estudio del sistema nervioso y sus } \\
\text { enfermedades. }\end{array}$ & $\begin{array}{l}\text { (Med) Estudio del sistema nervioso y sus } \\
\text { enfermedades. }\end{array}$ \\
\hline neurólogico -ca adj & De (la) neurología. & (Med) De (la) neurología o de su objeto. \\
\hline neurólogo -ga $m$ y $f$ & Especialista en neurología. & $(\mathrm{Med})$ Especialista en neurología. \\
\hline odontología $f$ & Estudio y tratamiento de los dientes. & (Med) Estudio y tratamiento de los dientes. \\
\hline odontológico -ca adj & De (la) odontología. & (Med) De (la) odontología o de su objeto. \\
\hline odontólogo -ga $m$ y $f$ & Especialista en odontología. & (Med) Especialista en odontología. \\
\hline ornitosis $f$ & $\begin{array}{l}\text { Enfermedad infecciosa de tipo respiratorio } \\
\text { que afecta a diversas aves y puede ser } \\
\text { transmitida al hombre. }\end{array}$ & $\begin{array}{l}(M e d) \text { Enfermedad infecciosa de tipo } \\
\text { respiratorio que afecta a diversas aves y puede } \\
\text { ser transmitida al hombre. }\end{array}$ \\
\hline otorrinolaringología $f$ & $\begin{array}{l}\text { Estudio del oído, la nariz y la garganta, y } \\
\text { de sus enfermedades. }\end{array}$ & $\begin{array}{l}\text { (Med) Estudio del oído, la nariz y la garganta, } \\
\text { y de sus enfermedades. }\end{array}$ \\
\hline
\end{tabular}




\begin{tabular}{|c|c|c|}
\hline otorrinolaringológico - ca adj & De (la) otorrinolaringología o de su objeto. & $\begin{array}{l}\text { (Med) De (la) otorrinolaringología o de su } \\
\text { objeto. }\end{array}$ \\
\hline otorrinolaringólogo -ga $m$ y $f$ & Especialista en otorrinolaringología. & (Med) Especialista en otorrinolaringología. \\
\hline paidología $f$ & $\begin{array}{l}\text { Estudio de la evolución fisiológica y } \\
\text { psicológica del niño. }\end{array}$ & $\begin{array}{l}\text { (Med) Estudio de la evolución fisiológica y } \\
\text { psicológica del niño. }\end{array}$ \\
\hline palpación $f$ & $(\mathrm{Med})$ Acción de palpar [1] & Acción de palpar [1]. Esp en Med. \\
\hline \multirow[t]{2}{*}{ patología $f$} & $\begin{array}{l}\text { Estudio de las enfermedades y de los } \\
\text { trastornos que causan en el organismo. }\end{array}$ & $\begin{array}{l}(\mathrm{Med}) \text { Estudio de las enfermedades y de los } \\
\text { trastornos que causan en el organismo. }\end{array}$ \\
\hline & $\begin{array}{l}\text { b) Conjunto de enfermedades o trastornos } \\
\text { [de alguien o algo]. }\end{array}$ & $\begin{array}{l}\text { b) Conjunto de enfermedades o trastornos [de } \\
\text { alguien o algo]. } \\
\text { c) Enfermedad. }\end{array}$ \\
\hline patológico -ca adj & $\begin{array}{l}\text { De (la) patología. b) De (la) enfermedad o } \\
\text { que la implica. }\end{array}$ & $\begin{array}{l}\text { (Med) De (la) patología o de su objeto. b) De } \\
\text { (la) enfermedad o que la implica. }\end{array}$ \\
\hline patólogo -ga $m$ y $f$ & Especialista en patología. & $(\mathrm{Med})$ Especialista en patología. \\
\hline plaquetario -ria adj & $(\mathrm{Med}) \mathrm{De}(\mathrm{las})$ plaquetas. & (Fisiol) De (las) plaquetas. \\
\hline pleuropulmonar adj & $(\mathrm{Med})$ De la pleura y los pulmones. & (Anat) De la pleura y los pulmones. \\
\hline podología $f$ & $\begin{array}{l}\text { Especialidad médica que trata de las } \\
\text { afecciones y deformidades de los pies, } \\
\text { cuando el tratamiento de estas no rebasa los } \\
\text { límites de la cirugía menor. }\end{array}$ & $\begin{array}{l}(\mathrm{Med}) \text { Especialidad médica que trata de las } \\
\text { afecciones y deformidades de los pies, cuando } \\
\text { el tratamiento de estas no rebasa los límites de } \\
\text { la cirugía menor. }\end{array}$ \\
\hline podológico -ca adj & De (la) podología. & (Med) De (la) podología o de su objeto. \\
\hline podólogo -ga $m$ y $f$ & Especialista en podología. & $(\mathrm{Med})$ Especialista en podología. \\
\hline $\begin{array}{l}\text { post partum (lat; pronunc cor- } \\
\text { riente, /pos-pártum/) loc adj }\end{array}$ & $\begin{array}{l}\text { Posterior al parto. } \mathrm{Tb} \mathrm{n} \mathrm{m} \text {, referido a } \\
\text { período. }\end{array}$ & $\begin{array}{l}\text { I loc adv } 1 \text { (Med) Después del parto. Tb } n m \\
\text { referido a período. } \\
\text { II loc adj } 2 \text { (Med) Posparto } T b n . m .\end{array}$ \\
\hline premenstrual $a d j$ & $\begin{array}{l}(\mathrm{Med}) \text { Que precede inmediatamente a la } \\
\text { menstruación. }\end{array}$ & $\begin{array}{l}\text { (Fisiol) Que precede inmediatamente a la } \\
\text { menstruación. }\end{array}$ \\
\hline priápico -ca adj & (Lit) $[$ Hombre] que tiene priapismo. $T b n$. & (Med) [Hombre] que tiene priapismo. $T b n$. \\
\hline priapismo $m$ & $\begin{array}{l}\text { (Med) Erección anormal y gralm. dolorosa } \\
\text { del pene sin apetito venéreo. } 2 \text { Exaltación } \\
\text { exagerada del impulso sexual en el } \\
\text { hombre. }\end{array}$ & $\begin{array}{l}\text { (Med) Erección anormal y gralm. dolorosa del } \\
\text { pene sin apetito venéreo. } 2 \text { (Med) Exaltación } \\
\text { exagerada del impulso sexual en el hombre. }\end{array}$ \\
\hline profundo - da $a d j$ & $\begin{array}{l}\text { (Med) [Oligofrénico] cuya edad mental no } \\
\text { sobrepasa nunca los siete años. Tb, más } \\
\text { raro, referido a la enfermedad. }\end{array}$ & $\begin{array}{l}\text { (Psicol) [Oligofrénico] cuya edad mental no } \\
\text { sobrepasa nunca los siete años. Tb, más raro, } \\
\text { referido a la enfermedad }\end{array}$ \\
\hline $\begin{array}{l}\text { psicogeriatra }(t b, \quad \text { raro, } \\
\text { sicogeriatra) } m \text { y } f\end{array}$ & Especialista en psicogeriatría. & $(\mathrm{Med})$ Especialista en psicogeriatría. \\
\hline $\begin{array}{l}\text { quinesiología (tb con la grafia } \\
\text { kinesiología) } f\end{array}$ & $\begin{array}{l}\text { Estudio de los movimientos del cuerpo } \\
\text { humano y tratamiento de las afecciones } \\
\text { relativas a ellos. }\end{array}$ & $\begin{array}{l}(\mathrm{Med}) \text { Estudio de los movimientos del cuerpo } \\
\text { humano y tratamiento de las afecciones } \\
\text { relativas a ellos. }\end{array}$ \\
\hline \multirow[t]{2}{*}{ quiropráctico -ca adj } & I adj. 1 De (la) quiropráctica [2] & I adj. 1 (Med) De (la) quiropráctica [2] \\
\hline & $\begin{array}{l}\text { II n A f } 2 \text { Sistema de tratamiento mediante } \\
\text { manipulaciones en diversas partes del } \\
\text { cuerpo, esp. en la columna vertebral. B } m \text { y } \\
f 3 \text { Especialista en quiropráctica. }\end{array}$ & $\begin{array}{l}\text { II } n \text { A } f 2(\mathrm{Med}) \text { Sistema de tratamiento mediante } \\
\text { manipulaciones en diversas partes del cuerpo, } \\
\text { esp. en la columna vertebral. B } m \text { y } f 3(\mathrm{Med}) \\
\text { Especialista en quiropráctica. }\end{array}$ \\
\hline radiología $f$ & $\begin{array}{l}\text { Parte de la medicina que estudia las } \\
\text { radiaciones, esp. los rayos X, en sus } \\
\text { aplicaciones al diagnóstico y tratamiento } \\
\text { de las enfermedades. }\end{array}$ & $\begin{array}{l}(\mathrm{Med}) \text { Parte de la medicina que estudia } \\
\text { las radiaciones, esp. los rayos } \mathrm{X} \text {, en sus } \\
\text { aplicaciones al diagnóstico y tratamiento de } \\
\text { las enfermedades. }\end{array}$ \\
\hline
\end{tabular}




\begin{tabular}{|c|c|c|}
\hline radiológico -ca adj & De (la) radiología. & (Med) De (la) radiología o de su objeto. \\
\hline radiólogo - ga $m$ y $f$ & Especialista en radiología. & $(M e d)$ Especialista en radiología. \\
\hline rectal adj & $(\mathrm{Med}) \mathrm{De}(1)$ recto. & (Anat) $\mathrm{De}(1)$ recto. \\
\hline reflexología $f$ & (Med) Estudio de los actos reflejos [2]. & $\begin{array}{l}\text { (Med) Sistema de masaje aplicado a } \\
\text { determinados puntos de los pies y de las manos, } \\
\text { para quitar tensión o curar enfermedades. } 2 \\
\text { (Psicol) Estudio de los actos reflejos [2] en la } \\
\text { conducta. }\end{array}$ \\
\hline reumatología $f$ & $\begin{array}{l}\text { Especialidad médica que trata de las } \\
\text { afecciones reumáticas. }\end{array}$ & $\begin{array}{l}\text { (Med) Especialidad médica que trata de las } \\
\text { afecciones reumáticas. }\end{array}$ \\
\hline reumatológico -ca adj & De (la) reumatología. & (Med) De (la) reumatología o de su objeto. \\
\hline reumatólogo -ga $m$ y $f$ & Especialista en reumatología. & $(\mathrm{Med})$ Especialista en reumatología. \\
\hline rinología $f$ & $\begin{array}{l}\text { Especialidad médica que versa sobre la } \\
\text { nariz. }\end{array}$ & $\begin{array}{l}\text { (Med) Especialidad médica que trata de la } \\
\text { nariz y sus enfermedades. }\end{array}$ \\
\hline rinológico - ca adj & De (la) rinología. & (Med) De (la) rinología o de su objeto. \\
\hline $\begin{array}{l}\text { roentgenografía } \quad \text { (pronunc } \\
\text { corriente, } / \text { rengenografía/) } f\end{array}$ & (Med) Radiografía. & (Med, raro) Radiografía. \\
\hline
\end{tabular}

roentgenográfico-ca (pronunc Radiográfico. (Med, raro) Radiográfico.

corriente, /rengenografiko/) adj

\begin{tabular}{|c|c|c|}
\hline $\begin{array}{l}\text { roentgenoterapia } \quad \text { (pronunc } \\
\text { corriente, /rengenoterápia) } f\end{array}$ & $\begin{array}{l}\text { (Med) Radioterapia (tratamiento con rayos } \\
\mathrm{X} \text { ). }\end{array}$ & $\begin{array}{l}\text { (Med, raro) Radioterapia (tratamiento con rayos } \\
\mathrm{X} \text { ). }\end{array}$ \\
\hline $\begin{array}{l}\text { roentgenterapia (pronunc cor- } \\
\text { riente, /rengenterápia/) } f\end{array}$ & (Med) Roentgenoterapia. & (Med, raro) Roentgenoterapia. \\
\hline
\end{tabular}

saburroso -sa adj (lit o Med) Saburral. 2 [Diente] que tiene (lit o Med) Saburral. 2 (lit o Med) [Diente]
sarro. 3 De(l) sarro de los dientes. que tiene sarro. 3 (lit o Med) De(1) sarro de los dientes.

\begin{tabular}{|c|c|c|}
\hline silicoso -sa $a d j$ & Silicótico. $T b n$. & (Med) Silicótico. $T b n$ \\
\hline silicótico -ca adj & Que padece silicosis. & $\begin{array}{l}\text { (Med) De la silicosis o que la implica. } 2 \text { (Med) } \\
\text { Que padece silicosis. } T b \text { n, referido a pers. }\end{array}$ \\
\hline susceptible $a d j$ & $\begin{array}{l}1 \text { b) (Med y Vet) Que tiene cierta } \\
\text { predisposición [a una enfermedad (compl } \\
\text { de)]. Tb sin compl. }\end{array}$ & $\begin{array}{l}1 \mathrm{~b})(\mathrm{Med}) \text { Que tiene cierta predisposición [a } \\
\text { una enfermedad (compl de)]. Tb sin compl. }\end{array}$ \\
\hline tanatofilia $f$ & $\begin{array}{l}(\mathrm{Med}) \text { Gusto exagerado por todo lo que } \\
\text { rodea al fenómeno de la muerte. }\end{array}$ & $\begin{array}{l}\text { (lit o Psicol) Gusto por todo lo que rodea al } \\
\text { fenomeno de la muerte. }\end{array}$ \\
\hline terapeuta $m$ y $f \neg$ & Pers. que se dedica a la terapéutica [2]. & (Med) Pers. que se dedica a la terapéutica [2]. \\
\hline \multirow[t]{2}{*}{ terapéutico -ca adj } & 1 De (la) terapéutica. & $\begin{array}{l}\text { I adj } 1 \text { (Med) De (la) terapéutica [2] o que sirve } \\
\text { para tratar enfermedades. }\end{array}$ \\
\hline & $\begin{array}{l}\text { II f } 2 \text { Tratamiento o curación de } \\
\text { enfermedades. }\end{array}$ & $\begin{array}{l}\text { II } f 2 \text { (Med) Tratamiento o curación de } \\
\text { enfermedades. }\end{array}$ \\
\hline terapia $f$ & Terapéutica [2]. & $\begin{array}{l}\text { (Med) Tratamiento de una enfermedad. Frec } \\
\text { con un adj o compl especificador. Tb fig., fuera } \\
\text { del ámbito técn. b) Psicoterapia (tratamiento de } \\
\text { las enfermedades, esp. mentales, por métodos } \\
\text { psicológicos) }\end{array}$ \\
\hline tetraplejía (tb tetraplejia) $f$ & Parálisis de las cuatro extremidades. & (Med) Parálisis de las cuatro extremidades. \\
\hline
\end{tabular}




\begin{tabular}{|c|c|c|}
\hline transferencia $f$ & $\begin{array}{l}2(\mathrm{Med}) \text { Vinculación afectiva, frec. de } \\
\text { carácter sexual, entre el paciente de una } \\
\text { cura psicoanalítica y el médico que le trata. }\end{array}$ & $\begin{array}{l}2 \text { (Psicol) Fenómeno por el que un sujeto } \\
\text { proyecta sobre una pers. o cosa un estado } \\
\text { afectivo experimentado previamente en } \\
\text { relación con otra. Frec. referido a la relación } \\
\text { médico-enfermo. }\end{array}$ \\
\hline ulcerativo -va adj & Que produce úlcera. & (Med o lit) Que produce o implica úlcera. \\
\hline urología $f$ & $\begin{array}{l}\text { Parte de la medicina referente al aparato } \\
\text { urinario. }\end{array}$ & $\begin{array}{l}(\mathrm{Med}) \text { Parte de la medicina referente al aparato } \\
\text { urinario. }\end{array}$ \\
\hline urológico -ca adj & De la urología. & (Med) De la urología o de su objeto. \\
\hline urólogo -ga $m$ y $f$ & Especialista en urología. & (Med) Especialista en urología. \\
\hline vasoconstricción $f$ & $\begin{array}{l}(\mathrm{Med}) \text { Disminución del calibre de los vasos } \\
{[3] .}\end{array}$ & $\begin{array}{l}\text { (Fisiol y Med) Disminución del calibre de los } \\
\text { vasos [3]. }\end{array}$ \\
\hline vasoconstrictor -ra adj & $\begin{array}{l}(\mathrm{Med}) \text { Que causa vasoconstricción. Tb n m, } \\
\text { referido a agente o fármaco }\end{array}$ & $\begin{array}{l}\text { (Fisiol y Med) Que causa vasoconstricción. } T b \\
n \text { m, referido a agente o fármaco. }\end{array}$ \\
\hline vasodepresor -ra adj & $\begin{array}{l}(\mathrm{Med}) \text { Que causa depresión colapso de los } \\
\text { vasos }\end{array}$ & $\begin{array}{l}\text { (Fisiol y Med) Que causa depresión o colapso } \\
\text { de los vasos [3]. }\end{array}$ \\
\hline vasodilatación $f$ & $(\mathrm{Med})$ Dilatación de los vasos . & (Fisiol y Med) Dilatación de los vasos [3]. \\
\hline vasodilatador -ra $a d j$ & $\begin{array}{l}(M e d) \text { Que causa vasodilatación. Tb } \mathrm{n} \mathrm{m} \text {, } \\
\text { referido a agente o fármaco. }\end{array}$ & $\begin{array}{l}\text { (Fisiol y Med) Que causa vasodilatación. } T b n \\
m \text {, referido a agente o fármaco. }\end{array}$ \\
\hline vasomotor -ra adj & $\begin{array}{l}\text { (Med) } 1 \text { Que produce los movimientos } \\
\text { de contracción y dilatación de los vasos. } \\
T b \text { n referido a agente o nervio. } 2 \text { De (la) } \\
\text { constricción o dilatación de los vasos. }\end{array}$ & $\begin{array}{l}1 \text { (Fisiol y Med) Que produce los movimientos } \\
\text { de contracción y dilatación de los vasos [3]. } \\
\text { Tb } n \text { m, referido a agente o nervio.2 (Fisiol y } \\
\text { Med) De (la) constricción o dilatación de los } \\
\text { vasos [3]. }\end{array}$ \\
\hline vibroterapia $f$ & Tratamiento terapéutico con vibraciones & $\begin{array}{l}\text { (Med) Tratamiento terapéutico con vibraciones } \\
\text { [1]. }\end{array}$ \\
\hline vicariante $a d j$ & $(\mathrm{Med})$ Vicario [2]. & (Med o Bot) Vicario [2] o sustituyente. \\
\hline virosis $f$ & $\begin{array}{l}\text { (Med y CNat) Enfermedad producida por } \\
\text { virus. }\end{array}$ & $\begin{array}{l}\text { (Biol y Med) Enfermedad producida por virus } \\
\text { [1]. }\end{array}$ \\
\hline $\begin{array}{l}\text { vómito negro (o, más raro, } \\
\text { prieto) } m\end{array}$ & Fiebre amarilla. & (Med, hist) Fiebre amarilla. \\
\hline
\end{tabular}

\section{ANEXO VI}

Entradas eliminadas

\begin{tabular}{ll}
\hline abiotrófico -ca $a d j$ & $($ Med $)$ Que tiene degeneración de la vitalidad y disminución de resistencia \\
\hline arrítmicamente $a d v$ & $($ Med o lit $)$ De manera arrítmica \\
\hline $\begin{array}{l}\text { cervicofacial }(t b, \text { raro, con la grafia } \\
\text { cérvico-facial) } a d j\end{array}$ & $($ Med $)$ Del cuello y la cara. \\
\hline cervitorácico $a d j$ & $(M e d)$ Del cuello y el tórax. \\
\hline criogenina $f$ & $(M e d)$ Antitérmico empleado en la tuberculosis. \\
\hline diagnósticamente $a d v$ & $(M e d)$ De manera diagnóstica. 2 En el aspecto diagnóstico. \\
\hline endovenosamente $a d v$ & $(M e d)$ De manera endovenosa. \\
\hline
\end{tabular}




\begin{tabular}{|c|c|}
\hline epidemiológicamente $a d v$ & $(\mathrm{Med})$ De manera epidemiológica. $2(\mathrm{Med})$ Desde el punto de vista epidemiológico \\
\hline ergoftalmología $f$ & $\begin{array}{l}\text { (Med) Especialidad de la oftalmología que estudia los problemas del ojo en relación con } \\
\text { el trabajo. }\end{array}$ \\
\hline esteatópigo -ga adj & (Med) Que presenta exagerada gordura en las nalgas. $T b n$, referido a pers. \\
\hline farmacológicamente $a d v$ & $(\mathrm{Med})$ De manera farmacológica. 2 (Med) En el aspecto farmacologico [1]. \\
\hline hemodinámicamente $a d v$ & (Med) En el aspecto hemodinámico [1]. \\
\hline ileus $m$ & (Med) Íleo. \\
\hline Inmunológicamente $a d v$. & $(\mathrm{Med})$ En el aspecto inmunológico. \\
\hline inmunopatología $f$ & $(\mathrm{Med})$ Estudio de las respuestas de inmunidad [21 asociadas con la enfermedad. \\
\hline Inmunoterapia $f$ & (Med) Tratamiento de las enfermedades infecciosas por la producción de inmunidad. \\
\hline inmunoterápico -ca adj & (Med) De (la) inmunoterapia. \\
\hline Intramuscularmente $a d v$ & $(M e d)$ Dentro del músculo. \\
\hline Intrauterinamente $a d v$. & (Med) Dentro del útero. \\
\hline novocaínico adj & (Med) De (la) novocaína. \\
\hline profilácticamente $a d v$ & $(M e d)$ De manera profiláctica. \\
\hline sintomatológicamente $a d v$ & $(\mathrm{Med})$ De manera sintomatológica. \\
\hline subcutáneamente $a d v$ & (Med) Por via subcutanea. \\
\hline situs $m$ & (Med) Sitio o lugar. $T b$ (lit) fig, fuera del ámbito técn. \\
\hline tetánicamente $a d v$ & $(M e d)$ De manera tetánica. \\
\hline tromboembólico -ca adj & $(\mathrm{Med}) \mathrm{De}$ (la) embolia u oclusión completa de un vaso por un trombo. \\
\hline tromboflebítico -ca adj & $(\mathrm{Med}) \mathrm{De}(\mathrm{la})$ tromboflebitis. \\
\hline
\end{tabular}

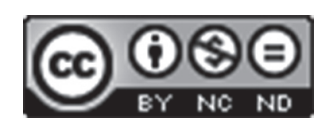

Este obra está bajo una licencia de Creative Commons

Reconocimiento-NoComercial-SinObraDerivada 4.0 Internacional. 